UNIVERSIDADE DE SÃO PAULO INSTITUTO DE PSICOLOGIA

\author{
ELIZABETH DOS REIS SANADA
}

\title{
SUPERDOTAÇÃO E PSICANÁLISE UMA QUESTÃO DO DESEJO
}




\section{ELIZABETH DOS REIS SANADA}

\section{SUPERDOTAÇÃO E PSICANÁLISE UMA QUESTÃO DO DESEJO}

Projeto de Pesquisa apresentado ao Instituto de Psicologia da Universidade de São Paulo como requisito para o Exame de Qualificação de Mestrado.

Área de concentração: Psicologia Escolar e do

Desenvolvimento Humano

Orientador: Profa. Dra. Walkíria H. Grant

SÃO PAULO

2001 


\title{
SUPERDOTAÇÃO E PSICANÁLISE UMA QUESTÃO DO DESEJO
}

\author{
ELIZABETH DOS REIS SANADA
}

BANCA EXAMINADORA

Prof $^{\mathrm{a}}$. Dr ${ }^{\mathrm{a}}$. Walkiria Helena Grant

Prof $^{\mathrm{a}}$. Maria Cristina Machado Kupfer

Prof. Dr. Christian Ingo Lenz Dunker

Dissertação defendida e aprovada em: $\underline{\text { 24/10/2001. }}$. 
Para

Meu irmão, Alexandre.

Minha mãe,

que me ensinou o caminho das letras.

E, meu pai,

que me ensinou o caminho do amor...

Sem o qual nenhum caminho poderia ser trilhado. 


\title{
AGRADECIMENTOS
}

"Há homens que lutam um dia e são bons.

Há homens que lutam um ano e são melhores.

Há homens que lutam muitos anos e são muito bons.

Porém, há homens que lutam a vida inteira, e estes homens são imprescindíveis.”

\author{
Bertold Brecht
}

À Profa. Dra. Walkiria Helena Grant, pessoa imprescindível em sua luta, em sua ética, respeito e exemplos profissional e pessoal, os meus agradecimentos especiais. Por todo apoio, dedicação e amizade com que me acolheu em todos os momentos deste trabalho. Por compartilhar como ninguém suas experiências e conhecimentos, transmitindo lições que se estenderão ao longo de todo o meu percurso clínico, acadêmico e, sobretudo, como ser humano. À você, mulher e amiga a quem eu aprendi a admirar e que tanto me ensinou nos últimos anos, o meu mais sincero e carinhoso muito obrigada! 
Meus agradecimentos também à Profa. Dra. Maria Cristina M. Kupfer por seu exemplo como profissional e como pessoa que, em sua simplicidade, sabe como ninguém demonstrar a sabedoria dos verdadeiros mestres. E, principalmente pela confiança a mim dispensada, fator indispensável para que eu pudesse começar a trilhar este caminho.

Ao Prof. Dr. Christian Ingo Lenz Dunker que já numa época remota de meu processo de formação pôde compartilhar seus conhecimentos não só no âmbito da Filosofia, mas, sobretudo, no âmbito da vida, transmitindo a partir de sua postura lições de ética, de respeito e comprometimento com a transmissão de saber. E, que agora me brinda ao acompanhar de perto esse momento tão importante, no qual espero poder fazer jus, com meu trabalho, ao exemplo recebido.

Ao Prof. Dr. Leandro de Lajonquière pelas valiosas contribuições prestadas na ocasião de meu Exame de qualificação, e pelo legado que seus escritos oferecem ao campo da psicanálise.

À Profa. Dra. Maria Helena de Souza Patto pelo apoio e orientação dedicados a mim, mesmo antes de ingresso na Pós Graduação, tendo comparecido como figura fundamental para que este sonho se realizasse.

À Elaine T. Dal Mas Dias, à Leda M. Lepiane Artigas e à Velia T. P. Ancares de Cotsifis, três mulheres de inestimado valor que, em diferentes momentos de minha vida, têm contribuído para minha formação profissional e, sobretudo, pessoal.

A todos os colegas do grupo de orientação pelo companheirismo, pelas discussões tão promissoras que tanto me ajudaram na elaboração de meu trabalho final.

Meus agradecimentos especiais ao amigo Leandro Alves Rodrigues dos Santos por todo incentivo dedicado, e por sua participação em momentos e decisões tão importantes em minha vida.

A todos os profissionais da equipe do Projeto Objetivo de Incentivo ao Talento (POIT), em especial ao Prof. Alfredo Antônio Fernandes, à Cristina Cupertino, Cristina Colavite e Christian eVita, peças fundamentais no processo de viabilização da coleta de dados.

Aos pais e crianças que contribuíram tão lindamente com seus relatos para a realização deste trabalho.

A Edson Kenzo Sanada, meu mais novo e querido companheiro neste caminho que se inicia, por todo amor e atenção recebidos.

Ao CNPq que financiou esta pesquisa. 
"Era uma vez um positivista.

Media crânios, media versos, lia quadros.

Traçava planos e esferas. Legislava biomecânica.

Domando o acaso morreu de razão".

Fernando Bonassi 


\section{SUMÁRIO}

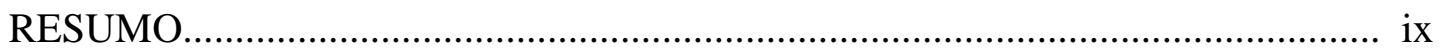

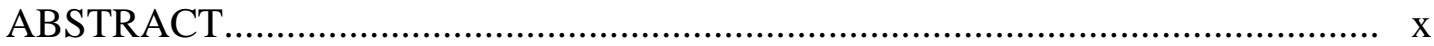

1. INTRODUÇÃ

1.1.1. A superdotação e as diferentes concepções acerca da construção do

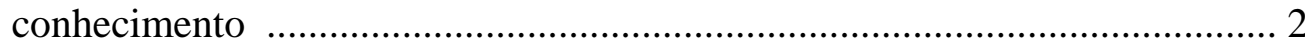

1.2. Superdotação: a constituição cognitiva em sua relação com a constituição psíquica - um problema de pesquisa ........................................................ 12

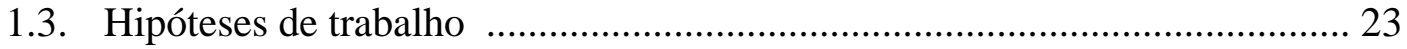

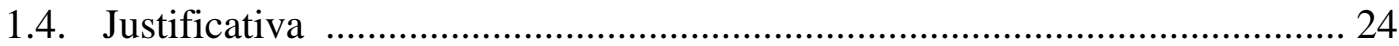

1.5. Metodologia, objetivos e limites de pesquisa ............................................. 24

2. A superdotação na neurose: uma articulação entre o desejo de saber e

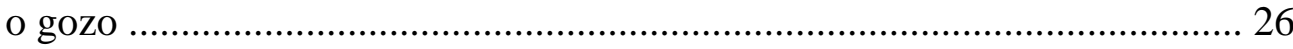

3. Superdotação: uma leitura pelo avesso .................................................... 52

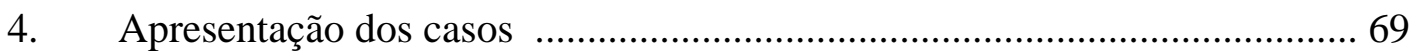

4.1. Soledad: um desejo de infância. .............................................................. 70

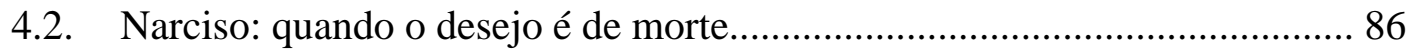

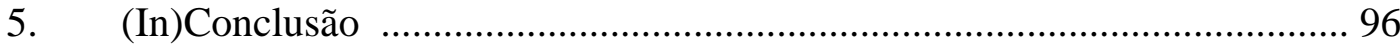

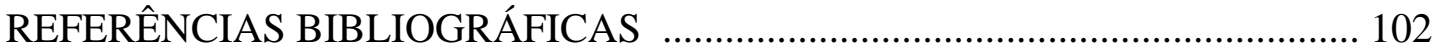




\section{RESUMO}

SANADA, Elizabeth dos Reis. Superdotação e psicanálise: uma questão do desejo. São Paulo, 2001. 110p. Dissertação (Mestrado). Instituto de Psicologia, Universidade de São Paulo.

O presente trabalho busca discutir psicanaliticamente um tema até então prevalecente no campo da psicologia e, profundamente arraigado a uma concepção genética e determinista de homem - a superdotação. Trata-se de um assunto intrinsecamente relacionado ao conceito de inteligência, sendo abordado pela psicologia clássica a partir de três grandes vertentes: a biológica, a ambientalista e a interacionista. Sendo assim, ao longo dos capítulos, buscamos situar de que maneira o modo descritivo como a psicologia aborda essa questão acaba por isolar o superdotado numa condição que impossibilita qualquer alternativa de abordagem que considere o seu discurso e que enfoque os aspectos concernentes à subjetividade. Num contraponto, propomos uma leitura psicanalítica do tema, enfocando preponderantemente os casos de neurose, partindo da hipótese de que a constituição cognitiva se encontra em estreita relação com a constituição psíquica do sujeito. Defendemos, assim, a tese de que a superdotação se constitui numa forma peculiar de responder ao desejo materno e ao fantasma parental, podendo ser pensada como um sintoma na medida em que incorre na transformação do mal-estar, próprio da estruturação neurótica, num sofrimento oriundo da colagem do sujeito ao significante superdotado. A partir dessa premissa, propomos uma articulação entre o desejo de saber em Freud e em Lacan, tendo como pressuposto que as questões referentes à inteligência, neste referencial, sofrem um deslocamento dos aspectos biológico, ambientalista e/ou interacionista, estabelecendo-se sob o primado da sexualidade, estando, em muito, associada ao modo como o sujeito se encontra referido à castração e à demanda do Outro. Como material de pesquisa, seguindo o método psicanalítico, foram utilizados os relatos de entrevistas gravadas com duas crianças diagnosticadas como superdotadas e com seus respectivos pais, onde se pôde acompanhar de que modo responder desse lugar - o de superdotado - surgia como uma forma de atender ao desejo parental. A conclusão da pesquisa confirma a hipótese de que a constituição psíquica possa influir no processo de constituição cognitiva do sujeito, embora admita também a necessidade de uma predisposição inata da criança para a superdotação, articulando a questão simbólica - advinda da incidência do significante e do desejo - aos registros do imaginário e do real.

Descritores: Superdotação, psicanálise, desejo.

Desejo de saber, constituição subjetiva, constituição cognitiva, fantasmática parental, sexualidade.Clínica psicanalítica. 
SANADA, Elizabeth dos Reis. The Gifted child and Psycho-analysis: one question of the wish. São Paulo, 2001. 110p. Master Thesis. Instituto de Psicologia, Universidade de São Paulo.

This work seeks for a Psycho-analistic discussion on a prevailing issue until now, at least - in the field of Psychology, which is deeply rooted on a genetic and determinist concept of man: the gifted. It's about an issue strongly related to the concept of intelligence, approached by classic Psycho-analisis from three main points of view: the biologic, the environmental and the interactional ones. So, as long as the chapters flow, we try to show how the descriptive way Psychology approaches this issue isolates the gifted on a condition which makes impractical any alternative approach that may consider his speech and focus the factors concerning to subjectivity. On the other hand, we propose a Psycho-analistic reading on the issue focusing on the neurosis cases since the hypothesis that the cognitive constitution is closely related with the Psychic constitution of the subject. So, we defend the thesis that overgift is a unique way of being responsive to mother wish and the parental ghost, and it can be concerned as a symptom as it turns the indisposition currently related to neurotic structure on a suffering that proceeds from the link of the person to the gifted significant. Starting from this premise, we propose an articulation between the Wish of Knowing on Freud and Lacan, presupposing that the issues concerning to intelligence, in this reference, suffer a displacement of the biologic, environmental and/or interactional factors, setting itself under the primacy of sexuality, and being strongly associated to the way the person is referred to castration and the Other demands. As research matter, following the Psycho-analistic method, it was used the reports of recorded interviews with two children diagnosed as gifted and their parents, in which it was possible to watch how to respond from this situation — of being a gifted - appears as a way of attend upon parental wish. The conclusion of such a research ratifies the hypothesis that the Psychic constitution may affect on the cognitive constitution process of the subject, though it also admits the need of a innate predisposition of the children to be a gifted, articulating the symbolical issue - which comes from the incidence of the significant and the wish — to the records of the imaginary and the real.

Descriptives: Overgift, Psycho-analisis, wish.

Wish of Knowing, subjective constitution, cognitive constitution, parental ghost, sexuality. Psycho-analistic clinic. 


\section{INTRODUÇÃO}

"Não é na via da consciência que o sujeito se reconhece, existe outra coisa e um mais-além. Sendo este mais além fundamentalmente desconhecido pelo sujeito, fora do alcance de seu conhecimento, ele coloca, ao mesmo tempo, a questão de sua estrutura, de sua origem e de seu sentido".

Jacques Lacan

Esta pesquisa trará como objetivo central uma tarefa difícil: discutir psicanaliticamente um tema até então prevalecente no campo da psicologia e, profundamente arraigado a uma concepção genética e determinista de homem - a superdotação.

Ao longo dos capítulos, buscamos situar de que maneira o modo como a psicologia aborda essa questão, isto é, pautada numa leitura absolutamente descritiva do superdotado, acaba por isolá-los numa condição que impossibilita qualquer alternativa de abordagem que considere o discurso desses sujeitos e que enfoque os aspectos pertinentes à subjetividade.

Este é o percurso que se apresenta no primeiro capítulo, no qual, a partir de um levantamento teórico, tentamos demonstrar que mesmo em determinadas vertentes psicanalíticas - como a kleiniana - por exemplo, encontramos dificuldades para tomar as relações num outro referencial que não o fenomenológico.

É, ao final deste capítulo, que apresentamos uma leitura que se coloca numa outra direção e que se encontra pautada na teoria de Freud e Lacan. Esses autores, ao discutirem a noção de estrutura e de inconsciente estruturado como linguagem, nos permitem analisar as relações em sua dimensão simbólica.

Assim, é no segundo capítulo que passamos a discutir mais detalhadamente o que, a partir dos estudos realizados por Maud Mannoni (1988b) em A criança retardada e mãe, se coloca como nossa primeira hipótese de trabalho: a idéia de que 
a superdotação se desenvolve a partir de uma resposta do sujeito ao desejo materno, constituindo-se, portanto, como um sintoma, sendo que para isto, empreenderemos um estudo sobre o processo de estruturação em psicanálise.

Discutiremos ainda neste capítulo questões relacionadas ao desejo de saber e ao gozo com base na concepção freudo-lacaniana, apontando para os aspectos da sexualidade que se conjugam na dinâmica do superdotado, sobretudo, na neurose. Utilizaremos para esta análise, entre outros, os trabalhos freudianos sobre a infância de Leonardo da Vinci e os estudos desenvolvidos por Maria Cristina Kupfer (1990) acerca do desejo de saber.

A partir do terceiro capítulo, apresentaremos a necessidade de se rever o conceito de superdotação, tendo como referência a leitura de Lacan acerca dos discursos.

No quarto capítulo, nos deteremos na apresentação e discussão do material de nossa pesquisa, o qual se constituirá na análise do relato de duas crianças, com idade de onze e doze anos, diagnosticadas como superdotadas, no sentido de verificar o modo como se posicionam frente ao significante superdotado e de que maneira isto se coloca em relação à fantasmática parental. Com respeito a este último fator, apresentam-se também as entrevistas realizadas com os pais.

Finalmente, na conclusão, discutiremos os resultados a que chegamos após essas leituras.

Passemos, portanto, à discussão da concepção de superdotação no campo da psicologia.

\subsection{A superdotação e as diferentes concepções acerca da construção do conhecimento}

O estudo da superdotação tem se constituído preponderantemente no campo da psicologia. Com base nos dados levantados nesses estudos - dentre os quais destacamos aqueles realizados por Novaes (1979) -, chega-se à conclusão de que a porcentagem de indivíduos superdotados, na sociedade brasileira, varia de 5\% a 20\% da população, dependendo dos critérios adotados para classificá-los. 
Esses critérios de classificação e identificação mostram-se dirigidos a responder aos aspectos manifestos do comportamento desses indivíduos e, geralmente, encontram-se pautados na noção de quociente intelectual - Q.I. - que relaciona a idade mental com a idade cronológica.

Esta marca se manteve atrelada ao conceito de superdotação desde os estudos de Terman (1925) que, envolvido na construção dos primeiros testes psicométricos, definiu o superdotado como sendo aquele indivíduo que alcançava os mais altos resultados em testes de inteligência.

Desde então, uma série de definições tem sido articulada sendo que, no Brasil, a conceituação oficialmente aceita descreve a superdotação como um notável desempenho e/ou elevada potencialidade em aspectos como: capacidade intelectual geral, aptidão acadêmica específica, pensamento criador e produtivo, talento especial para artes visuais, dramáticas e musicais elou capacidade psicomotora (Novaes, 1979).

Desta forma, o indivíduo superdotado passa a ser caracterizado como sendo aquele que "apresenta facilidade no desempenho escolar e qualidade superior nos relacionamentos sociais, relatando-se que longe de se constituir um problema clínico, a superdotação parece facilitar a adaptação a mudanças" (Rosenberg, 1973). Colocam-se como providos não só de uma inteligência superior, como de um desenvolvimento físico, social e emocional privilegiado em relação ao indivíduo com nível de inteligência média.

É ao falarmos da adaptação a mudanças que nos deparamos com um dos principais conceitos envolvidos na superdotação, ou seja, a inteligência.

A inteligência é um conceito ainda não esclarecido pelos autores e se encontra freqüentemente definida, no campo da psicologia, como uma capacidade de adaptação a mudanças, sendo abordada a partir de três grandes vertentes: a biológica, a ambientalista e a interacionista. Veremos que à medida que nos deslocamos em direção a cada uma dessas vertentes, encontraremos também diferentes maneiras de conceber a superdotação.

Com relação à abordagem biológica, muitos trabalhos foram elaborados, sendo possível citar, por exemplo, as pesquisas realizadas por Galton (1869). Este autor considerava a inteligência como hereditária. Realizou um estudo com famílias constituídas por indivíduos reconhecidamente brilhantes na sociedade da época, a 
partir do que concluiu que as aptidões humanas, como a inteligência, eram herdadas exatamente da mesma forma como os aspectos constitucionais e físicos do mundo orgânico.

Além disso, há que se acrescentar ao caráter biológico as determinações político-sociais atreladas ao conceito de inteligência a partir do século XIX, quando a superdotação era reconhecida como um atributo próprio das classes sociais dominantes da época, denunciando a discriminação velada que se estabelecia a partir da máxima "igualdade para todos”: ou seja, aqueles que não obtinham êxito em sua busca de ascensão eram considerados incapazes, sendo-lhes atribuídas qualidades naturais relacionadas a sua origem racial, ao seu potencial intelectual, entre outras. Desta maneira, eram rotulados de preguiçosos, débeis, encobrindo-se assim a falta de oportunidades que se reservava às classes menos favorecidas.

A esse respeito, Maria Helena Patto se coloca como uma das autoras mais fervorosas na crítica às discriminações ocorridas, sobretudo na Educação, a partir dessa luta de classes. Em seu livro A produção do fracasso escolar, de 1990, ela cita Hobsbawm, dizendo:

Uma das crenças fundamentais do século XIX era a de que “o mundo da classe média estava livremente aberto a todos. Portanto, os que não conseguiam cruzar seus umbrais demonstravam uma falta de inteligência pessoal, de força moral ou de energia que automaticamente os condenava ou, na melhor das hipóteses, uma herança racial ou histórica que deveria invalidá-los eternamente, como se já tivessem feito uso, para sempre, de suas oportunidades”. (Hobsbawm, 1979, p. 219-220).

E Patto acrescenta: “entre os supostos inaptos, estavam os trabalhadores pobres das cidades industriais” (p.38).

Além disso, a autora marca o caráter estigmatizante que a psicologia assume na época, sobretudo a psicologia diferencial, servindo como importante instrumento para a classe dominante em seu processo de exclusão das classes menos favorecidas.

Neste sentido, Galton também comparece como uma das figuras de destaque, sendo um dos precursores dos testes de inteligência e tendo transitado, segundo Patto, pelas quatro vertentes da psicologia das diferenças individuais. 
Entretanto, é sabido que Galton ia muito mais longe em suas pretensões do que meramente provar a determinação genética das capacidades psíquicas individuais, nas palavras de Patto, "estava em seus planos interferir nos destinos da humanidade através da eugenia, ciência que visava controlar e dirigir a evolução humana, aperfeiçoando a espécie através do cruzamento de indivíduos escolhidos especialmente para este fim”.(p.38).

Interessante notar como em diferentes momentos da história a busca por uma raça superior se revela, ainda que de maneira mascarada, sendo a inteligência considerada um dos atributos para esta superioridade. Tal fator talvez aponte não só para uma questão político-social, mas principalmente para uma característica psíquica do sujeito que tenta de algum modo ser único, ser Um, ser todo, ser completo.

Nota-se que mesmo com o estabelecimento dos testes de inteligência, por exemplo, e a criação da chamada curva padrão, os escores obtidos em sua maioria servem de parâmetro para ressaltar pejorativamente as diferenças daqueles que se encontram em déficit em relação à norma, quando os que se situam acima, de modo geral, são exaltados, - ainda que saibamos das conseqüências de tal valorização, e que a norma, neste caso, não passa de um encobrimento do recalcado que insiste em retornar.

Atualmente essa valorização pôde ser acompanhada através do próprio discurso dos pais entrevistados para a pesquisa, que relataram sua escolha por um colégio específico por saberem, de antemão, do empreendimento dispensado pelo colégio na busca e na estimulação de crianças superdotadas, o mesmo podendo ser destacado com relação ao discurso dos educadores.

Este caráter pode ser observado ainda, em termos históricos, através de uma fala de Maria Helena Patto em seu texto, quando esta nos diz acerca do trabalho realizado por Claparède nos meados do século XX:

Claparède é um fiel representante das inquietações e desejos de seus pares: quer aprimorar instrumentos de medida que rastreiem as diferenças individuais, quer saber quem são os retardados e os bem dotados o mais precocemente possível, defende a criação de classes especiais para os primeiros e de escolas especiais para os 
segundos (...) tudo isto em nome do menor desperdício e menor desgaste individual e social. (p. 43).

Imbuídos deste ideal reformista, vários países embrenharam-se no processo de identificação dos indivíduos sub ou superdotados da população infantil, sobretudo, no período que se segue a primeira grande guerra no sentido de restabelecer o progresso, oferecendo opções condizentes de escolarização para essas crianças.

Com relação especificamente aos superdotados, havia o objetivo claro de que esses indivíduos pudessem contribuir com seu potencial para o crescimento econômico, científico e social desses países.

Neste sentido, Patto, conclui:

Desde então, os testes psicológicos ingressaram nas escolas e passaram a fazer parte de seu cotidiano nos países capitalistas centrais. É a partir desta época que, nos países dependentes, educadores mais progressistas sofrem forte influência do que se passa nos meios educacionais da Europa e da América do Norte e começam a lutar pela introdução da psicometria e da pedagogia nova em seus países. (p.43).

Dando continuidade aos estudos anteriores, acerca da determinação biológica da inteligência, tivemos ainda Freehill (1961), autor que reafirmou a posição defendida por Galton ao colocar que as habilidades da aprendizagem estavam sujeitas a seleção genética.

Atualmente, um dos estudos mais recentes nesta abordagem tem sido desenvolvido por Clark (1998). Trata-se de uma pesquisa realizada por uma bióloga que trabalha com superdotados, avaliando as diferenças biológicas mensuráveis que ocorrem em conseqüência da interação entre padrão genético do indivíduo e seu ambiente.

A autora menciona que o cérebro desses sujeitos é mais acelerado e integrativo em suas funções. Nesta perspectiva, superdotação significa "um alto nível de inteligência e indica um desenvolvimento avançado e acelerado das funções cerebrais" (Clark, 1998, p. 13). 
Entretanto, só o fator biológico não é capaz de abarcar toda a constituição do indivíduo, há que se considerar aspectos como o ambiente no qual ele se insere e a relação que estabelece com o mesmo.

Neste sentido, desenvolveram-se outras abordagens que considerassem tais aspectos como o caso da abordagem ambientalista e da abordagem interacionista. Passando à discussão do que as caracteriza, percebe-se que o estudo do termo inteligência torna-se difícil se adotada apenas uma das vertentes isoladamente. Isto porque os fatores geralmente encontram-se associados, sendo a diferença estabelecida de acordo com a ênfase posta num ou noutro dos aspectos levantados acima.

Nesta perspectiva, Landau (1990) e Câmara (1999) colocam-se como seguidoras da abordagem ambientalista, e reafirmam a necessidade de se considerar os fatores externos, dizendo que a mera capacidade de adquirir conhecimentos, desenvolver habilidades e compreender a experiência não é condição suficiente para que se constitua um elevado nível de inteligência. Faz-se necessário um ambiente rico em estímulos, em informações, oportunidades e experiências que sejam oferecidas para o indivíduo.

Câmara (1999) considera a influência ambiental tão importante quanto a genética, enfatizando que será através da interação das experiências do ambiente com as características individuais que se daria o desenvolvimento intelectual do sujeito.

Piaget (1973) por sua vez, encontra-se numa abordagem interacionista, situando-se como um dos autores que parte de um ponto de vista biológico para desenvolver uma teoria da inteligência que inclui a influência do cultural. Concebe a inteligência como a capacidade de adaptação do indivíduo ao meio, procurando destacar os aspectos qualitativos dos processos cognitivos, assim como a interação do indivíduo com o meio ambiente.

A partir deste referencial, autores como Lewis e Michalson (1985) colocam que "a superdotação não reside nem no indivíduo, nem no ambiente, mas é a sua interação que produz ou prediz efeitos no desenvolvimento subseqüente".

São esses três modelos de conceber a inteligência - biológico, ambientalista e interacionista -, que permitem caracterizar o superdotado no que se refere a seu desempenho intelectual e, ao mesmo tempo, apontar quais seriam seus correlativos na esfera social e emocional. 
Com base nessa concepção, diversos autores buscaram enumerar as características do superdotado, não havendo, no entanto, no que diz respeito aos fatores emocional e social, um consenso quanto ao fato dos altos índices de desenvolvimento nestas áreas se constituírem como preexistentes à superdotação e, portanto, como favorecedores de um elevado nível intelectual, ou como conseqüência deste.

Neste sentido, autores como Novaes (1979), Ortiz (1981) e Landau (1990) colocam que, em relação ao desenvolvimento mental, o elevado nível de inteligência do superdotado se manifesta através de uma maior capacidade de análise, síntese, dedução e generalização. O que, por sua vez, favorece a utilização de grande quantidade de informações e o desenvolvimento de poder criativo e de julgamento características marcantes nesses sujeitos.

Robinson (1987) relata algumas características de personalidade, observadas em crianças precoces, que parecem interferir sobre o potencial intelectual, favorecendo sua manifestação. São elas: a tolerância à frustração, a concentração e a persistência nas tarefas difíceis, a capacidade de atenção durante um longo período quando uma tarefa é absorvente, um nível de atividade e de energia moderadamente alto e o prazer em dominar um conhecimento.

Do ponto de vista emocional e social, os autores anteriormente citados concordam que os superdotados, de um modo geral, buscam chamar a atenção para si, mostram-se questionadores e extremamente curiosos, gostam de assumir desafios e enfrentam dificuldades facilmente.

No entanto, estudos realizados por Freeman (1985) admitem que as crianças superdotadas sentem-se diferentes dos outros, embora atribuam essa diferença à sua capacidade intelectual superior.

Conclusões semelhantes foram encontradas nas pesquisas realizadas por Pati (1994), marcando mais claramente uma dificuldade de adaptação desses indivíduos. Os resultados revelaram que os superdotados freqüentemente sentem-se sozinhos e pouco compreendidos e aceitos pela maioria das pessoas.

Os sujeitos entrevistados pela autora relataram viver um conflito frente à sua autenticidade, ficando entre duas soluções que percebiam como insatisfatória. Por um lado, renunciar à superdotação, a fim de obterem melhores condições de 
igualdade e, conseqüentemente, de convivência com as pessoas. Ou, por outro lado, assumir a superdotação, apesar de se sentirem diferentes e distantes dos demais.

Câmara (1999) afirma que os superdotados são capazes de se integrar a grupos naturalmente, mas ressalta que eles costumam ter menos amigos que as outras crianças. A isto, acrescenta-se um estudo realizado por Freeman (1980) que constata que os amigos de crianças superdotadas geralmente são mais velhos que elas.

Esses últimos estudos introduzem especificidades que permitem questionar a supremacia do superdotado em todas as áreas do desenvolvimento.

Além desses, associa-se ainda nossa experiência ao longo de oito anos de ensino numa escola de educação infantil particular, junto a crianças superdotadas, período no qual também foi possível observar algumas particularidades referentes ao relacionamento intra e interpessoal das mesmas, o que colocou em pauta a necessidade de uma nova leitura da superdotação.

Verificamos que, embora essas crianças mantivessem um excelente desempenho intelectual, demonstravam dificuldade de interação com os colegas, dificuldade em lidar com seus próprios limites - quanto à possibilidade de errar, principalmente -, e com aqueles estabelecidos pelo meio. Além disso, era perceptível um semblante de tristeza e introspecção que as marcava - seus questionamentos remetiam sempre a temas como a morte, o sentido da vida, as origens, a solidão, entre outros -, associado a este, havia momentos de negação de seus sentimentos, de racionalização ou ainda, momentos de regressão - estes caracterizados, sobretudo, por fala infantilizada e birras.

Outro fator relevante para a reflexão dizia respeito ao modo como essas crianças eram percebidas por seus professores. Desenvolviam-se duas posições antagônicas: uma onde o superdotado era considerado como antipático, onipotente e intransigente. Outra, na qual era exaltado por seus professores, sendo colocado como aluno-modelo, uma vez que respondia prontamente ao ideal narcísico do mestre.

Tanto no primeiro como no segundo caso, o que se notava era que o aluno superdotado se tornava alvo de discriminação, e passava a ser reconhecido a partir de um rótulo que o esvaziava de sua singularidade.

Colocava-se, portanto, a necessidade de verificar mais detalhadamente o que ocorria com essas crianças em termos subjetivos. 
Entretanto, diante dos dados levantados anteriormente, o que foi possível apreender dos estudos citados é que eles favorecem, de um modo geral, a identificação, descrição comportamental do superdotado e, a partir disso, a elaboração de programas educacionais. Mesmo os trabalhos que apontam para questões emocionais o fazem, partindo de um ponto de vista fenomenológico, relevando a segundo plano as questões subjetivas e, sobretudo, o próprio discurso desses sujeitos.

O superdotado não fala, ele é falado. A partir do momento em que lhe é outorgado esse rótulo, ele se vê seqüestrado num discurso social, frente ao qual não encontra outra forma de reconhecimento que não seja desempenhar esse papel, ainda que sob a pena de se apagar subjetivamente, passando a responder desde um ponto continuamente iluminado pelo aspecto intelectual.

Neste sentido, cabe citar o que Mannoni (1988a) descreve acerca da relação médico-paciente - em alguns momentos, muito semelhante ao que ocorre na psicologia. A autora coloca que na medida em que as palavras do médico transformam a história do indivíduo num mito morto, tornam inconseqüente o depoimento do paciente, que procurará então se exprimir no sintoma.

Isto colocado na questão da superdotação se mostra como importante objeto de reflexão. No lugar do médico se encontra, quase sempre, a figura do psicólogo que, tendo como instrumento de avaliação os testes, classifica o indivíduo, legitimando a função anteriormente determinada pela família.

O sujeito passa a ser visto a partir do significado que a superdotação comporta em cada sociedade. Cumprir o papel que lhe foi atribuído e validado pelo social se torna a única solução. A busca incessante pelo conhecimento será o seu sintoma.

Como é sabido, este sintoma responde perfeitamente ao ideal da Educação e se reflete, na escola, na elevada valorização do aluno que reproduz, tal e qual, os conteúdos apresentados pelo professor.

O status atribuído à inteligência em nossa sociedade e reproduzido pela escola, acaba por ser mais um agente de influência na constituição psíquica do sujeito, que se torna cada vez mais alienado nessa rede de relações. 
Mas o que dizer com relação à parcela de contribuição do sujeito para seu sintoma? Tratar-se-ia somente de um enredamento do social ou haveria algo que o sujeito extrairia dessa nomeação?

Pensamos que, na verdade, diferentes fatores se associam: primeiramente o que Lacan denominou ao longo de sua obra como real do corpo, e que poderíamos classificar como a parcela orgânica envolvida na superdotação, parcela esta que não é tomada pela psicanálise, senão como um limite. A segunda, como já dissemos anteriormente, diz respeito à função determinada pelas figuras parentais que, pela via do significante, incide sobre o corpo da criança, fazendo o bordejamento do real. E, por fim, agrega-se a vertente do social, trazendo de modo mais marcante a dimensão imaginária, visando a partir do discurso científico, sobretudo através da universalização de conceitos e da criação de objetos de consumo, uma tentativa de escamoteamento da divisão no sujeito. Ou seja, tentando dar sustentação, preenchimento para a falta deixada pelas marcas do significante.

Diríamos ainda, que essas três dimensões, respectivamente, real, simbólico e imaginário, encontram-se interligadas, influenciando-se mutuamente no processo de constituição do sujeito. Sujeito que embora sofra as conseqüências, muitas vezes, negativas deste processo, também extrai sua parcela de gozo da mesma, ponto este que será mais bem discutido no próximo capítulo desta dissertação.

Sendo assim, podemos concluir que se os estudos descritos anteriormente respondem à demanda educacional e psicológica - à medida que permitem classificar os indivíduos e propor modelos de adaptação e, de conseqüente alienação -, o mesmo não ocorre quanto à capacidade de investigação da subjetividade.

Uma forma viável de analisar a questão da superdotação, considerando os fatores subjetivos a ela relacionados, dar-se-ia através da psicanálise. Infelizmente, encontramo-nos num campo pouco explorado psicanaliticamente. Os estudos que se dedicam a pesquisar os aspectos cognitivos do sujeito, geralmente o fazem pela via do déficit de inteligência, do fracasso escolar, da inibição intelectual...

Diante disso, poderíamos pensar em tomar esses estudos em seu reverso para, logo atribuir as conclusões resultantes ao caso da superdotação, mas a questão não é tão simples. Temos que considerar o que Kupfer (1990) coloca ao dizer da dificuldade de se formular uma teoria da inteligência na psicanálise. 
Se esses estudos mostram-se úteis, no caso da superdotação, é por trazerem uma nova dimensão para pensar os processos cognitivos, desta vez, intrinsecamente relacionados à constituição psíquica do sujeito, introduzindo outros personagens nessa dinâmica - como os pais, imaginários ou simbólicos -, e abrindo campo para a escuta do sujeito e para o modo como este se posiciona frente ao significante "superdotado".

\subsection{Superdotação: a constituição cognitiva em sua relação com a constituição psíquica - um problema de pesquisa}

Deparamo-nos, em psicanálise, pelo menos com duas posições diferentes de conceber a formação psíquica do sujeito, a primeira delas se trata, nas palavras de Bleichmar (1994) "de uma corrente teórica que concebe o inconsciente como existente desde as origens, e a constituição psíquica, em seu conjunto, desde uma determinação endógena" (p.125). Estamos a falar da teoria kleiniana e do que fundamenta o pensamento de seus seguidores, dentre os quais faremos menção a Wilfrid Bion. E, por outro lado, encontramos uma leitura pautada na questão da linguagem, sendo a referência os estudos de Freud e Lacan.

Como vimos, no caso da psicologia, qualquer mudança com relação à concepção de inteligência, introduziria diferenças na maneira de conceitualizar a superdotação. Se, por exemplo, a inteligência era tomada como um fator meramente biológico, a superdotação também o era, e, assim, sucessivamente, quando atribuída ao ambiente ou aos fatores interacionistas.

No caso da psicanálise isto não será diferente, perceberemos ao longo de algumas leituras o quanto a maneira específica como cada teoria abordará o psiquismo refletir-se-á no modo como a mesma pensará a questão cognitiva.

O que é importante verificar, nas duas abordagens psicanalíticas citadas anteriormente, é o modo como cada uma introduz a figura materna no processo de constituição psíquica do sujeito e como isto se reflete na leitura dos processos cognitivos.

As pesquisas realizadas com base num referencial kleiniano demonstram que a busca pelo conhecimento se inicia numa fase bastante precoce do desenvolvimento 
infantil, onde a criança possui um ego ainda incipiente, pouco estruturado, o que faz com que ela vivencie fantasias, em sua maioria, persecutórias, próprias da posição que Melanie Klein nomeia como esquizo-paranóide.

O processo de busca de conhecimento, nesta vertente, tem como mola propulsora os impulsos anais sádicos, sendo que o corpo da mãe será tomado pela criança como o primeiro objeto de seu interesse.

Klein (1923) denominou de pulsão epistemofílica o impulso da criança em satisfazer sua curiosidade penetrando nos objetos. Os impulsos anais-sádicos, associados ao de penetração (epistemofílicos), visam à apropriação dos conteúdos do interior do corpo materno.

Para Melanie Klein (1923) a pulsão epistemofílica não é criada pela libido, mas sim pelo sadismo arcaico com o qual a criança ataca e ao mesmo tempo conhece o corpo da mãe.

Os ataques sádicos primeiramente dirigidos à mãe se estendem posteriormente à figura paterna, sendo que a criança tem a fantasia que ambos são mordidos, despedaçados, cortados e esmagados, o que traz a ansiedade de que a criança seja punida pelos pais em conjunto (Klein, 1930).

Segundo a autora, a ansiedade é o que põe em movimento o mecanismo de identificação e contribui para que a criança - na medida que seja capaz de separar os conteúdos do mundo interno dos conteúdos do mundo externo -, iguale os órgãos atacados com outras coisas. Isto faz com que esses novos objetos também se tornem ansiógenos, estabelecendo-se um processo constante de novas equiparações que formam a base do simbolismo e do interesse em novos objetos.

No artigo O papel da escola no desenvolvimento libidinal da criança, Melanie Klein (1923) coloca que o processo de simbolização permite o deslocamento da libido para outros objetos e atividades ligadas ao instinto de conservação e lhe empresta um componente prazeroso. Desse modo, tarefas ou atividades que em si mesmas não tinham tonalidade prazerosa, passam a tê-la, permitindo de modo socialmente aceito a descarga disfarçada de uma energia cujos fins estavam socialmente proibidos.

Segundo a autora, o que possibilita a passagem da identificação à simbolização é a atuação da repressão. No entanto, se a repressão for muito intensa essa passagem não se dá, fazendo com que a realidade e os objetos reais mantenham 
o significado de reflexos do mundo interno temido e das imagos ameaçadoras. Como conseqüência, os estímulos do mundo externo podem causar tanto alarme quanto o domínio fantasiado dos objetos internalizados, que tomam as rédeas de toda a iniciativa e aos quais o ego se sente obrigado a entregar a execução de todas as operações intelectuais.

No texto de 1930 A importância da formação do símbolo no desenvolvimento do ego, Klein conclui que o desenvolvimento intelectual estaria diretamente relacionado ao tipo de fantasias da criança e à sua capacidade egóica para abarcá-las, sendo essencial, para que ocorra um desenvolvimento favorável do desejo de conhecimento, que a criança sinta que o corpo da mãe está bem e não foi ferido.

Segal (1993) concebe uma outra forma de pensar a passagem da identificação à simbolização, estabelecendo uma distinção entre equação simbólica e simbolismo propriamente dito. No primeiro caso a autora diz que o símbolo é confundido com o objeto à medida que o ego - via identificação projetiva - também o é, constituindo-se uma característica própria da posição esquizo-paranóide. No segundo caso, coloca que há uma maior diferenciação e separação entre ego e objeto, que faz com que o símbolo seja visto como uma criação do ego e reconhecido como sendo separado do objeto que ele representa. Neste sentido, a passagem à posição depressiva seria uma das condições essenciais para que ocorresse a simbolização e o adequado desenvolvimento da criança.

Para Segal (1993) o que se constituiria como a base para o pensar e para a formação dos símbolos seria a discriminação entre a realidade interna e externa, para isto as fantasias seriam utilizadas como hipóteses a serem testadas no encontro com a realidade.

Bion (1988) também parte de um princípio semelhante para explicar como se inicia o pensamento na criança, no entanto, ele denomina as hipóteses a serem testadas de preconcepções e agrega a elas mais dois processos: o de realização negativa e o de formulação de contido e continente.

Estes processos se desenvolvem sob o fundo das experiências de satisfação ou de frustração arcaicas. Desta forma, o pensamento, na teoria bioniana, teria sua origem na intersecção entre um objeto desejado e a consciência da ausência desse objeto, o que equivaleria a dizer que o pensamento se fundaria na própria experiência de frustração. 
Neste sentido, o que Bion (1988) chama de realização negativa é caracterizado pela frustração da criança ao se deparar com a ausência do seio.

Para Bion (1988) "se a capacidade do bebê para suportar a frustração é grande, a percepção/experiência do 'não-seio' é transformada num pensamento, o que ajuda a suportar a frustração e possibilita usar o pensamento do 'não-seio' para pensar, isto é, para entrar em contato e suportar a perseguição e então excindi-la quando o seio externo chega novamente. Aos poucos esta capacidade se desenvolve numa habilidade para imaginar que o sentimento mau de ser frustrado está na verdade ocorrendo porque há um objeto bom que está ausente, mas que pode retornar" (p. 162).

A experiência do "não-seio" é o representante da frustração, da falta e é esta experiência que favorece o pensamento como uma possibilidade de suportar a frustração. Pode-se supor que essa experiência só se torna possível mediante a diminuição da persecutoriedade própria da posição esquizo-paranóide. Nesta posição, pode-se notar que não existe a ausência ou dependência de um objeto, uma vez que o objeto é percebido como uma extensão do ego da criança, num contraponto ao da posição depressiva, onde o objeto pode ser percebido como pertencente ao mundo externo e podendo faltar.

No que diz respeito à formulação do conceito de "continente/contido", Bion (1988) retoma a concepção de Klein acerca da identificação projetiva. Segundo o autor, "o bebê tem alguma espécie de percepção sensorial, necessidade ou sentimento que para ele parece ruim e do qual ele quer se livrar" (p.163). A seguir ele busca despertar estes mesmos sentimentos na mãe que servirá de continente para as angústias do bebê.

Bion (1988) considera esse tipo de identificação projetiva como "realística" uma vez que não é apenas uma fantasia onipotente, mas leva a um comportamento que desperta o mesmo tipo de sentimento na mãe. E conclui: "se a mãe é razoavelmente bem equilibrada e capaz daquilo que chamo de reverie, ela pode aceitar e transformar os sentimentos numa forma tolerável de modo que o bebê pode reintrojetá-los" (p.163).

Uma das funções maternas essenciais, portanto, nessa teoria, é permitir este jogo de identificação projetiva e, a seguir, introjetiva. Isto significa dizer que, para que possa abarcar o impacto emocional sofrido pela criança, torna-se fundamental 
que a mãe seja capaz de trabalhar esses conteúdos, de nomeá-los e devolvê-los para a criança.

Um estudo recente que aborda mais diretamente o desenvolvimento intelectual, considerando a influência dos pais no processo, foi articulado por Miller (1986), e se encontra publicado com o título O drama da criança bem dotada - como os pais podem formar (e deformar) a vida emocional dos filhos.

Neste trabalho, Miller (1986) dando continuidade à concepção defendida por Klein e Bion, parece tomar a influência dos pais, aqui em termos concretos, no sentido de atitudes e expectativas dirigidas à criança a fim de atender ao narcisismo parental, impedindo que esta possa se manifestar autenticamente.

Como conseqüência desse posicionamento dos pais, o desenvolvimento da personalidade da criança se dará de forma a somente revelar aquilo que dela é esperado, havendo um processo de fusão entre o que a criança é e aquilo que desempenha - o que favorece um distanciamento cada vez maior do que Winnicott denominou de self verdadeiro.

Miller utilizando este referencial, afirma que se estabelece um "estado de não-comunicação". Esse estado se manifesta num sentimento de vazio e de futilidade por parte desses sujeitos que, freqüentemente, se queixam de se sentirem "sem lugar no mundo", uma vez que o vazio sentido é real.

Para Miller, os pais encontram no "self falso" da criança a confirmação que buscavam, um substituto para suas próprias estruturas perdidas. A mãe “ama a criança como seu self-objeto, excessivamente, embora não da maneira que o filho precisa e sempre sob a condição de que ele manifeste o seu 'self falso'” (p.23).

A criança, neste caso, seria uma "vítima" do egoísmo dos pais, vendo-se forçada a atendê-los em seus ideais, sob o risco de perder o amor dos mesmos.

Se uma criança criada dessa forma não quer perder o amor de seus pais, deve aprender muito cedo a compartilhar, a dar, a fazer sacrifícios e a estar disposta a abster-se de gratificação - muito antes que seja capaz de verdadeiramente compartilhar ou da real predisposição de 'fazer sem esperar nada em troca' (Miller, 1986, p. 10).

O elevado desempenho intelectual, nesta perspectiva, surge como uma forma de atender ao ideal narcísico dos pais e ao mesmo tempo como uma função de 
suporte, sendo decisiva no fortalecimento dos mecanismos de defesa da criança para lidar com o distúrbio narcisístico favorecido pelas figuras parentais.

Considerando sua experiência de vinte anos de atendimento clínico, a autora descreve que os "pacientes bem dotados", por um lado, são louvados e admirados por seus talentos, por outro, nutrem um sentimento de insegurança e instabilidade, não sendo capazes de tirar proveito de suas realizações. Repetem frente a seus parceiros, amigos e demais pessoas que deles se aproximam a mesma posição tomada primeiramente em relação aos pais.

Miller coloca que atrás de tudo isso o que se encontra é a depressão, o sentimento de vazio e auto alienação, além de um senso de que suas vidas são destituídas de sentido.

Esses sentimentos sombrios virão à tona assim que a droga da grandiosidade falhar, assim que não estiverem 'no topo', definidamente não a 'superestrela', ou sempre que repentinamente sentirem que falharam em corresponder a uma imagem idealizada e na medida em que sentem que deviam aderir a ela. Então são atormentados pela ansiedade ou por profundos sentimentos de culpa e vergonha (Miller, 1986, p. 17).

Neste sentido, o conhecimento, a intelectualização cumprem a função de suturar uma falta ou de defender o sujeito de um ataque, ou de um roubo, por parte dos pais.

Após um estudo sucinto das abordagens que seguem um referencial kleiniano e neokleiniano, encontramos dois pontos que coincidem em ambas: a ênfase colocada na influência dos pais - como fator crucial para o desenvolvimento psíquico e, conseqüentemente, cognitivo do indivíduo -, e a noção de frustração como elemento a ser superado pela criança em sua relação objetal com as figuras parentais.

Vemos que a superação da frustração, nessa vertente, se constituiria numa pré-condição para a fundação de um aparato organizador do pensamento e de suas funções cognitivas.

Entretanto, cabe-nos ainda destacar uma diferença, em relação aos outros autores, na maneira como Miller (1986) aborda essa questão, permitindo apreender 
dois modos paradoxais de o sujeito se colocar em relação à intelectualização, isto é, tomando-a como uma forma de atender ao narcisismo dos pais e, ao mesmo tempo, de se defender deles.

Essa mudança de foco se torna a primeira possibilidade de se pensar os aspectos concernentes à superdotação como um sintoma do sujeito.

No entanto, precisamos antes nos deter num outro ponto fundamental, presente no âmago dessa vertente da psicanálise, que diz respeito à concepção que traz acerca das figuras parentais e, sobretudo, acerca da concepção de objeto.

Para apontar do que se trata no primeiro caso, consideramos bastante ilustrativa a descrição que Kupfer (1982) faz para demonstrar o que caracteriza por uma relação de interação, ou seja, uma relação onde o que prevalece é o campo da consciência, da razão - aspectos prevalecentes da chamada Psicologia do Ego -, e na qual se preconiza a existência de entidades biológicas, constituídas à priori, havendo sempre a determinação de uma sobre a outra.

É esta leitura - que permite considerar os pais como figuras objetivadas -, que nos coloca o risco de repetirmos aquilo mesmo que buscávamos criticar com relação às descrições e à fenomenologia da superdotação, fazendo com que apenas transportemos as questões, anteriormente relacionadas ao ambiente ou à capacidade biológica, para as relações familiares. Passando a discutir o caráter benévolo ou malévolo dos pais na vida de seus filhos, posicionamento este que não pode ser visto sem que se teça uma crítica.

Consideramos sim que as figuras parentais assumam um valor crucial no processo de constituição do sujeito e que isto se reflita em seu desenvolvimento cognitivo, mas acreditamos que tal influência se dê em termos de funções e não, necessariamente, sendo desempenhadas pelos pais biológicos ou mesmo por entidades reais. Trata-se de um processo lógico que perpassa as cadeias da linguagem na qual o sujeito se encontra enredado.

Com isto introduzimos uma outra leitura do psiquismo do sujeito, a qual consideramos atender mais diretamente aos propósitos dessa pesquisa, na medida em que abre espaço para algo que se coloca para além do biológico, apontando no sentido da estrutura, tal como articulado primeiramente por Freud e aprofundado, posteriormente, pelos estudos lacanianos. 
Neste sentido, Kupfer (1994) adepta deste segundo referencial psicanalítico, nos diz que a primeira mudança a se introduzir, a partir do que Lacan coloca, refere-se "à distinção entre pais imaginários e simbólicos - duas dimensões dos pais reais - que pode substituir a distinção entre pais reais e pais fantasiados", tal como eram apresentados na primeira corrente.

A autora coloca que, desta forma, os pais simbólicos podem ser entendidos como significantes, e cita Cazenave (1991) dizendo:

O par conjugal deve entender-se não como personagens parentais, mas como suas funções; como esses dois significantes que se substituem na metáfora paterna para produzir a significação da castração (Cazenave in Kupfer, 1994, p.109).

Se desejarmos compreender em que medida as figuras parentais podem influenciar o sujeito em sua constituição psíquica e cognitiva só poderemos fazê-lo na medida em que considerarmos que "pais e crianças encontram-se capturados em um mesmo campo, e determinados pelas mesmas leis: as do simbólico, da linguagem. Há, portanto, uma espécie de amarração discursiva, determinando e permitindo que haja circulação de doenças, palavras e efeitos entre eles, a ponto de o desaparecimento de um 'traço', no pai ou na mãe, poder provocar efeitos sobre seu filho” (Kupfer, 1994, p. 109).

Calligaris (1989) afirmara anteriormente essa condição ao colocar que “o interesse do conceito lacaniano de Outro é o de chamar a atenção sobre o fato de que a determinação de um sujeito se decide no campo da linguagem e segundo cálculos que não coincidem com laços intersubjetivos. Por patógenas que nos pareçam algumas situações familiares, na realidade não é possível deduzir destas situações coisa alguma sobre o destino do sujeito". E conclui dizendo: "O que faz o saber inconsciente de um sujeito não é algo que possa ser calculado a partir da singularidade dos membros de sua família. É algo que só pode ser calculado no discurso" (p.28).

É com relação a este ponto que se pode tecer as maiores críticas ao modo como o kleinianismo considera as relações do sujeito. Parafraseando Rosenberg (1994), “é ao colocar todo o peso da constituição subjetiva no pólo intrapsíquico e no inato que Melanie Klein - e por extensão todos os seus seguidores -, se priva da 
possibilidade de compreender o papel do Outro na fundação do inconsciente e na estruturação da fantasia” (p.40).

Segundo Bleichmar (1994), é a partir do pensamento de Lacan que se inaugura pela primeira vez a perspectiva de estabelecer uma relação entre o inconsciente da criança e o desejo parental.

A esse respeito, Mannoni (1989a) coloca que “a dinâmica pai-mãe-filho está em ação bem antes do nascimento da criança e reenvia cada um dos pais à maneira pela qual eles mesmos viveram seus édipos e ultrapassaram as distorções ligadas ao desejo de incesto" (p.64).

Assim, segundo a autora, “o sujeito a advir está marcado pela intersubjetividade e é a partir do lugar que ocupa no desejo da mãe - desejo este estruturado em função da história materna -, e da forma como o pai pode ou não exercer a dupla castração (tanto na mãe quanto na criança), que este sujeito poderá se constituir" (p.65).

Mannoni (1988b) ao colocar que a demanda da mãe em relação ao filho se constitui no invólucro do seu desejo perdido, faz uma menção à função que o superdotado ocupa para essa mãe, perguntando-se sobre o que ocorre quando a mãe solicita que o filho seja inteligente. E ela responde que, "na medida em que, por trás da sua demanda é de outra coisa que se trata, a criança permanecerá como uma sombra, tendo sido atribuído um lugar preciso à sua inteligência na fantasia materna. A relação mãe-filho vai estabelecer-se através de um prisma deformante. A criança não sabe que é chamada a desempenhar um papel para satisfazer o voto inconsciente da mãe (papel do superdotado, do débil, do doente). Sem o saber, ela é de certo modo, ‘raptada’ no desejo da mãe” (p. 43).

Vemos se perfilar um novo caminho para conceber as questões referentes à superdotação à medida que esta é colocada como um modo de atender ao desejo materno e, como tal, em estreita ligação com os aspectos da sexualidade dos pais e da criança, constituindo-se, como dito anteriormente, num sintoma do sujeito que se submete à condição de falo para a mãe.

Além disso, cabe-nos retomar o segundo ponto de nossa crítica à primeira vertente psicanalítica citada, e que diz respeito à concepção de objeto que nela se apresenta. Estabelecer uma distinção entre a forma como este é colocado, torna-se 
crucial para que possamos entender uma outra dimensão que se apresentará numa leitura lacaniana da superdotação, desta vez no que diz respeito ao gozo.

Quando Lacan (1957) discute a questão do objeto ele o faz primeiramente a partir de uma crítica frente à tomada da relação mãe-criança como uma relação real, acrescentando a esses dois elementos um terceiro, isto é, o falo - significante da falta, que os transpõe para uma dimensão imaginária e simbólica.

Para Lacan (1957) a realidade de que se trata na psicanálise é a Wirklichkeit simbólica e esta realidade nada mais é que aquela que se estabelece na dialética entre princípio do prazer e princípio da realidade e, que por sua vez, nos remete ao objeto justamente naquilo que este se apresenta como perdido, como falta de objeto - numa visão, portanto, bastante diferente daquela que o situava como materializado na figura do seio, por exemplo.

Neste sentido, torna-se imprescindível citar o que Lacan (1957) discute acerca dos textos de Freud, a fim de explicitar o modo como o sujeito se posiciona a partir da falta de objeto. Lacan coloca que "uma nostalgia liga o sujeito ao objeto perdido, através da qual se exerce todo esforço de busca. Ela marca a redescoberta do signo de uma repetição impossível, já que precisamente, este não é o mesmo objeto, não poderia sê-lo. A primazia dessa dialética coloca, no centro da relação sujeito-objeto, uma tensão fundamental, que faz com que o que é procurado não seja procurado da mesma forma que o que será encontrado. É através da busca de uma satisfação passada e ultrapassada que o novo objeto é procurado, e que é encontrado e apreendido noutra parte que não no ponto onde se o procura. Existe aí uma distância fundamental, introduzida pelo elemento essencialmente conflitual incluído em toda busca do objeto" (p.13).

Em outras palavras, seria ao redor desse objeto inapreensível que o sujeito se colocaria a trabalhar no sentido de reavê-lo, sendo a própria impossibilidade disso o que o manteria em movimento e, ao mesmo tempo, em permanente fracasso. Isto, nada mais é que a própria relação do sujeito com a castração e com o falo enquanto significante dessa falta. Estaríamos, desta forma, referidos ao desejo, naquilo que diz respeito ao movimento, e ao gozo, no que diz respeito à repetição.

Quanto a isto, Lacan (1957) conclui dizendo que "há uma diferença entre a concepção de objeto instaurada por Freud e aquela que concebe a possibilidade de 
um objeto plenamente satisfatório. Freud situa a busca pelo objeto no nível do que denominou de repetição e como tal impossível de saciar" (p. 14).

Colocaríamos ainda que é essa mesma concepção que nos autoriza a dizer que se o sujeito vive a buscar o objeto perdido desde sempre, visando um retorno ao primeiro momento mítico de completude com o Outro materno, o que ele deseja em última instância é a singularidade diante dos demais.

Sendo assim, as tentativas de estabelecimento de escores, normas e regras na tentativa de padronização do sujeito não são mais do que formas pelas quais se tenta conter o recalcado que insiste em se fazer presente.

A partir deste levantamento, pensamos que um estudo aprofundado destes pontos possa contribuir para elucidar o que se estabelece na dinâmica subjetiva do superdotado, no que tange ao modo como este se posiciona frente à castração e ao desejo do Outro -, sobretudo, quando isto significa passar de um mal-estar próprio do funcionamento psíquico na neurose para a ordem de um sofrimento -, possibilitando ainda verificarmos em que medida o fato de se posicionar desse lugar estaria direcionado a uma tentativa de suprir uma falta estrutural e, portanto, associado a um gozo específico.

\subsection{Hipóteses de trabalho}

Uma vez que discutimos o modo pelo qual a constituição cognitiva se encontra em estreita relação com a constituição psíquica, e que demonstramos a necessidade de se estabelecer uma nova leitura para a superdotação, capaz de abordar as questões referentes à singularidade do sujeito, apresentando-se para isto um estudo no referencial psicanalítico lacaniano, podemos situar os pontos que delinearão nossa pesquisa.

1) Uma proposição de que a superdotação se constitui numa forma peculiar do sujeito responder ao desejo materno e ao fantasma parental, colocando-se como algo que está para além da estrutura, comparecendo tanto na neurose quanto na perversão e psicose. E, podendo assumir, desta forma, o caráter de sintoma ou de suplência. É a partir dessa proposição que discutiremos a concepção psicanalítica do processo de estruturação psíquica, dando ênfase exclusivamente à constituição 
neurótica, buscando abordar, entre outros, conceitos como o de demanda, desejo, alienação, separação, traço unário, identificação e metáfora paterna; a fim de circunscrever de que maneira o sujeito se encontra referido ao significante superdotado e como isto se refletirá em sua relação com o saber.

2) Uma articulação entre o desejo de saber em Freud e em Lacan, tendo como pressuposto que as questões referentes à inteligência, neste referencial, se estabelecem sob o primado da sexualidade. Não sendo o desejo de saber outra coisa que o desejo de saber sobre o gozo sexual, e que coloca o sujeito em contato com a verdade da impossibilidade da relação sexual - ponto este a ser discutido com base na análise dos textos freudianos acerca da sexualidade da criança e da infância de Leonardo da Vinci, além dos estudos realizados por Kupfer (1990) sobre o tema.

3) A problematização do conceito de superdotação, sobretudo, naquilo que tange à ordem social, com base na leitura dos discursos que Lacan apresenta no seminário O avesso da psicanálise (1970), cujo intuito é apontar para o caráter cerceante que este conceito assume, ao ser engendrado e sustentado pelo discurso científico. Discurso este que, na modernidade, passa a desempenhar a função de nomeação do sujeito, impondo-lhe uma “ordem que é de ferro”, e, constituindo-se, portanto, num processo de alienação.

4) Como decorrência dos efeitos da intervenção analítica, apresentamos a discussão dos casos acompanhados no decorrer dessa pesquisa, tendo como objetivo apontar para o sofrimento vivido pelo sujeito superdotado, em detrimento a toda uma corrente que o situa como absoluto e superior em todas as áreas do desenvolvimento.

\subsection{Justificativa}

Esta questão torna-se pertinente, sobretudo se considerarmos que ela abre espaço para redirecionar a superdotação numa dimensão clínica, à medida que pode ser colocada como significante de um sintoma que faz sofrer. Sendo pensada nesses 
termos, contribui para a dismistificação do superdotado e possibilita-lhe outras maneiras de se posicionar em seu meio.

\subsection{Metodologia, objetivos e limites da pesquisa}

Lacan (1957) coloca que "no discurso sustentado por um sujeito, há algo que ultrapassa seu querer. O paradoxo, o imprevisto, o acidente produzem significantes que se engatam e geram efeitos de sentido. É aí que fica em jogo uma verdade num nível diferente do nível do eu do sujeito. Há alguma coisa que funciona no inconsciente mais além do par formado pelo eu e o outro, trata-se de uma entidade estrutural”.

É a partir deste referencial que buscamos situar a superdotação num outro contexto, para além dos determinantes biológicos, visando analisar os efeitos de linguagem que se produzem no sujeito a partir do momento em que lhe é reservado no fantasma parental o papel ou o lugar de superdotado.

Para isto, empreenderemos uma pesquisa pautada no estudo de cinco casos de crianças, na faixa etária entre seis e doze anos, todas diagnosticadas, em algum momento de suas vidas, como superdotadas, dentre os quais apresentaremos apenas dois, intitulados: "Soledad: um desejo de infância” e "Narciso: quando o desejo é de morte”. Crianças estas que nos foram encaminhadas para a pesquisa por meio da instituição de ensino particular, na qual estudam, e que desenvolve um programa específico para atender a todos os alunos que tenham interesse em buscar conhecimentos além daqueles desenvolvidos na sala de aula.

Com essas crianças foram desenvolvidas entrevistas, que foram gravadas, contendo aproximadamente uma hora de duração, e tendo como consigna “O que significa ser superdotado?”. Além disso, uma vez que um dos objetivos desta pesquisa é verificar o lugar que o superdotado ocupa na fantasmática parental e de que maneira isto pode relacionar-se ao seu desempenho intelectual, foram realizadas também entrevistas com os pais, tomando-se como consigna "O que significa ter um filho superdotado?”.

Esperamos que a apresentação dos casos, bem como a discussão teórica, possam contribuir no sentido de ampliar as investigações acerca do tema, 
principalmente no referencial psicanalítico, a fim de se repensar o conceito de superdotação, articulando as dimensões do real, simbólico e imaginário, respectivamente naquilo que elas correspondem ao fator orgânico envolvido, ao efeito de nomeação significante e ao caráter social atribuído ao superdotado. 


\title{
2. A SUPERDOTAÇÃO NA NEUROSE: UMA ARTICULAÇÃO ENTRE O DESEJO DE SABER E O GOZO
}

\author{
"O sujeito é levado a se comportar de \\ uma maneira essencialmente significante, \\ repetindo indefinidamente algo que lhe é, \\ propriamente falando, mortal”.
}

Jacques Lacan

Como dissemos anteriormente, este estudo tem por objetivo uma leitura da superdotação enfatizando exclusivamente a estrutura neurótica, embora saibamos de sua extensão também para a psicose, o autismo e a perversão.

Sendo assim, neste capítulo, empreenderemos uma descrição dos processos de constituição psíquica para, a seguir, adentrar os avatares da sexualidade infantil abrangendo inclusive a análise realizada por Freud (1910) acerca da infância de Leonardo da Vinci -, quando, então, articularemos a questão do desejo de saber e do gozo na superdotação.

Desta forma, dando início à nossa tarefa, sabemos que o instante em que a criança começa a interrogar de onde vêm os bebês, na teoria freudiana, equivaleria, em Lacan, a um questionamento do sujeito sobre o lugar que ele ocupa no desejo do Outro - “O que ele quer de mim, além do que me demanda?”.

Essa passagem corresponde ao momento da alienação significante, ao momento da carência do sujeito, no qual este aparece apagado sob o significante $S_{2}$. Trata-se do efeito afânise descrito por Lacan (1964).

A desaparição se dará a partir do surgimento de $S_{1}$ no campo do Outro que, por sua vez, representará o sujeito para outro significante $-S_{2}-$, condenando-o a desaparecer sob o mesmo.

Desta operação resulta o saber. Saber escandido pelo significante, marcando a divisão do sujeito. 
Vejamos de que modo essa lógica se desenvolve no processo de estruturação, para isso, comecemos por pensar como se dá a entrada desse sujeito no campo da linguagem.

Calligaris (1986) aborda essa questão colocando que o que se encontra, a princípio, no processo de estruturação é uma heterogeneidade entre o que ele demarcou como sendo o campo do Outro, o campo da linguagem, e o campo do sujeito - naquilo que este se apresenta como real do corpo.

No primeiro caso, estaríamos frente ao campo da linguagem, do qual se pode dizer que "Isso fala”. No segundo caso, encontrar-se-ia o sujeito ainda não constituído, puro corpo, objeto $a$, podendo-se designá-lo como nada.

O que fará o sujeito aceder à ordem significante, ao campo da linguagem? Uma questão sobre o desejo do Outro.

Se esse Outro, se esse Isso fala, Isso deseja. No entanto, o fato de que "Isso deseja” não significa ainda que deseje alguma coisa. O desejo não implica em nenhum objeto como alvo a ser alcançado: para que haja objeto é preciso que o desejo se transforme em demanda.

É preciso que esse Outro se constitua no lugar da fala que, ao ser enunciada pela primeira vez, venha a legiferar, conferindo, ao outro real, segundo Quinet (1998), sua obscura autoridade e provocando o fantasma (fantôme) da onipotência do Outro em que se instala a demanda do sujeito.

Assim, diríamos que a simples suposição de saber $\left(\mathrm{S}_{2}\right)$ acerca do desejo do Outro, já resulta numa operação crucial para a constituição subjetiva.

É essa suposição de saber que permitirá uma ligação entre o campo do Outro e o real do corpo, fazendo surgir o sujeito. É neste momento lógico estrutural situado por Lacan em diversos momentos de sua obra -, que se pode dizer que há um significante $\left(\mathrm{S}_{1}\right)$ que produz sujeito $(\$)$ para um outro significante $\left(\mathrm{S}_{2}\right)$, o primeiro significante existindo somente por um efeito retroativo deste último.

E, neste sentido, pode-se falar desse primeiro significante, desse $S_{1}$, como aquele que se constituirá como traço unário, tendo seu significado pautado no desejo materno, e encontrando-se metaforizado pelo Nome-do-Pai - $\mathrm{S}_{1}$ em torno do qual o sujeito articulará a cadeia significante -, sendo marcado por ele como sujeito dividido. 
É desse trajeto, que nasce alguma coisa definida, por Lacan (1970), como perda - o objeto $a$.

Em suma, é dessa operação, que o sujeito extrai uma significação mínima capaz de introduzi-lo na linguagem. Sendo esta passagem correspondente ao efeito afânise, descrito por Lacan em 1964, e que se refere ao momento da alienação significante, momento da carência do sujeito, no qual este aparece apagado sob o significante $S_{2}$.

Embora se constitua em alienação, cabe marcar que esse efeito pressupõe a intervenção da função significante do Nome-do-Pai, por meio mesmo do ato de nomeação, o que permite ao sujeito se reconhecer como não todo, como barrado e, assim, expor sua carência. O que, no entanto, não significa condição suficiente para que ocorra a separação.

O que se obtém, como resultado dessa primeira operação, é um saber suposto $-\mathrm{S}_{2}$ - que se superpõe ao desejo do Outro, de modo que o sujeito que era nada - $a$ - para esse desejo pode se constituir como uma significação para este saber. De qualquer forma, trata-se de um desejo que é indeterminado, sendo esta propriedade o que irá definir a significação do sujeito também como indeterminada.

Em outras palavras, poder-se-ia dizer que o sujeito que resulta dessa primeira metáfora - produto desse processo de recalcamento originário -, embora se encontre referido ao campo da linguagem, ainda não se constitui como um sujeito desejante. Encontra-se enlaçado à demanda absoluta e indeterminada do Outro materno. Demanda esta que surge a partir do próprio efeito imaginário, advindo da operação de recalcamento, e frente a qual o sujeito se coloca como objeto imaginário indeterminado, cuja significação é simbólica.

Como decorrência, ainda, deste processo, tem-se a articulação de um supereu, que vem falar do lugar dessa demanda indeterminada do Outro - supereu arcaico, representado pela figura materna -, e que é bem diferente daquele que se estabelece por ocasião do complexo de Édipo, a partir do pai.

Apreende-se, no primeiro caso, um mandato de gozo, mas que difere do “Goza!” do segundo tempo edípico. Tratar-se-ia, antes, de tomar o próprio corpo da criança como pertencente ao corpo materno, não tendo o sujeito outra saída senão atender à exigência de gozo endereçada pela mãe. Ou seja, no lugar de “Goza!”, encontrar-se-ia o imperativo “Me faça gozar com seu corpo!”. 
Neste ponto, segundo Calligaris (1986), o que se estabelece por parte do sujeito são defesas empreendidas no sentido de protegê-lo da demanda terrificante do Outro. Defesas autísticas, neuróticas, psicóticas, e, diríamos também perversas, a partir das quais poderá se posicionar frente a tal demanda.

No caso da neurose, por exemplo, para que se dê a transposição da alienação à separação faz-se necessário que se produza o recobrimento de duas carências - a do sujeito e a do Outro - sendo esta a saída neurótica ideal.

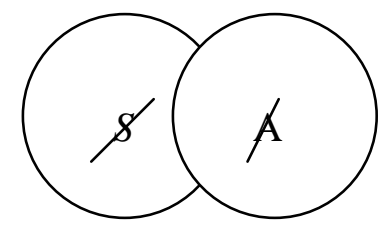

Assim, para que o sujeito pudesse se ver livre dessa condição alienante, e se constituir efetivamente como sujeito do desejo, haveria que entrar em cena uma segunda operação de recalque, uma nova metáfora. A partir, da qual um terceiro viesse a se interpor na relação dual mãe-criança, sendo capaz de delimitar a demanda indeterminada do Outro. Alguém suposto saber sobre o desejo da mãe.

Estamos a falar do recalque secundário, no qual o pai surgirá com interditor, veiculado pelo desejo materno, a fim de lhe instituir limites, que permitirão ao sujeito reconhecer sua própria falta, através da constatação da incompletude do Outro.

Dito de outro modo, trata-se aqui da função da metáfora paterna, função que irá circunscrever o saber, lhe dar um limite que, consequentemente, se estenderá à demanda do Outro. Esta, a partir de então, se tornará uma demanda determinada, dominada pelo saber do pai.

A partir desta intervenção, mudanças se verificarão também no nível do supereu que, uma vez alicerçada a metáfora paterna, continuará a consistir num imperativo de gozo, mas como falávamos anteriormente, desta feita, será um imperativo endereçado ao próprio sujeito, como a lhe dizer “Goza!”. Já não se referirá mais ao gozo do Outro, mas sim ao gozo fálico.

É por meio da intervenção da metáfora paterna que o sujeito poderá apreender a falta do Outro e, assim, sua própria falta.

Segundo Lacan (1958), será ao introduzir sua questão - acerca da origem dos bebês, por exemplo -, que o sujeito atacará a cadeia significante do Outro, no seu 
ponto mais débil, o do intervalo entre os significantes de sua demanda, entre $S_{1}$ e $S_{2}$, ali onde se esconde sua falta, encontrando-se, assim, com o desejo do Outro.

Encontrar este desejo no Outro e se colocar nesse lugar, enquanto falo imaginário (- $\varphi$ ), é condição para que se produza a separação. É neste momento que se passa do efeito afânise - efeito da alienação significante -, para a função afânise, quando o sujeito se faz objeto da falta do Outro, e se libera do peso afanísico do $\mathrm{S}_{2}$, excluindo-se da cadeia significante e entrando como objeto $a$.

Vejamos, portanto, como este momento crucial da constituição psíquica do sujeito pode contribuir para os enlaces de sua constituição cognitiva.

Como já foi dito anteriormente, o conceito de inteligência, num referencial psicanalítico, sofre um deslocamento de ênfase nos aspectos biológicos, ambientais e/ou interacionistas para centralizar-se nas questões referentes à sexualidade e ao desejo, introduzindo questões relacionadas à linguagem e ao estabelecimento de uma ordem fálica, que permeia o ser falante.

Sendo assim, pautados no processo de estruturação do sujeito na neurose, passamos à discussão das vicissitudes da sexualidade infantil, começando por circunscrever a dimensão do falo neste processo.

Neste sentido, Lacan (1957) coloca que "o falo só pode ser posto em jogo na medida em que seja necessário, num dado momento, simbolizar algum acontecimento, seja este a vinda tardia de uma criança para alguém que esteja em relação imediata com ela, ou ainda, para o próprio sujeito, a questão levantada sobre a sua maternidade e a posse de uma criança" (p.99).

Para explicarmos, mais detalhadamente, esse momento, recorreremos aos textos de Freud nos quais ele se põe a falar das investigações sexuais infantis, abrindo espaço para a formulação do desejo de saber e permitindo situar a superdotação em relação à sexualidade, naquilo que esta comporta de desejo e de gozo.

É a partir do texto sobre as Teorias sexuais infantis, publicado em 1908, que um caminho diferente começa a se construir, no qual Freud coloca o fator sexual como a mola propulsora do desenvolvimento intelectual. 
Freud inicia seus estudos preocupado em conhecer o que habilitaria uma criança para o mundo do conhecimento e quais seriam os determinantes psíquicos que a levariam a ser um "desejante de saber".

Neste texto, Freud (1908) começa a distinguir o que constitui o campo biológico e psíquico no que concerne à sexualidade, desvinculando-a de um fator meramente desenvolvimentista, e admitindo sua influência decisiva - sobretudo no que corresponde às teorias sexuais infantis -, para a formação dos sintomas.

A curiosidade sexual se estabelece, segundo Freud (1908), não por "alguma necessidade inata de causas estabelecidas; surge sob o aguilhão dos instintos egoístas que dominam a criança, quando é surpreendida - talvez ao fim do seu segundo ano pela chegada de um novo bebê" (p.215).

Ao se interpor um terceiro na relação entre a criança e os pais, coloca-se a ameaça de perda do amor parental, o que lhe desperta uma gama de sentimentos agressivos e de ciúmes em relação ao recém chegado.

É neste momento crucial de sua constituição que a criança verá se aguçar suas emoções e também sua capacidade de pensamento, o que lhe permitirá empreenderse em direção à busca de um sentido para sua existência - a princípio, através da formulação das teorias sexuais infantis e, posteriormente, por meio da sublimação, através de seu desenvolvimento intelectual.

Freud (1908) descreve que é "sob a instigação desses sentimentos e preocupações, que a criança começa a refletir sobre o primeiro grande problema da vida e perguntar a si mesma: 'De onde vêm os bebês?'” (p.216).

Ao introduzir esta questão e endereçá-la aos adultos, sobretudo aos pais a quem supõe um saber, a criança não almeja apenas resolver o enigma do nascimento dos bebês. Trata-se antes de um momento no qual ela se vê confrontada como sujeito ao desejo do Outro parental, o que significa estender a questão inicial para: "O que você quer de mim além daquilo que demanda?", ou ainda, "De que desejo eu nasci?”.

Trata-se de um ponto concernente ao próprio processo de constituição do sujeito. Processo onde a criança passaria de um primeiro momento de puro narcisismo dual, de completa alienação ao Outro materno, para um segundo estádio, caracterizado pelo complexo de Édipo, o que instituiria uma relação triádica, 
havendo a atuação de um terceiro elemento interditor da mônada mãe-criança, possibilitando, assim, a instauração do desejo.

É na passagem do primeiro momento deste processo à conclusão de seu segundo tempo, que irá se colocar por parte da criança uma série de perguntas endereçadas ao adulto, e que refletem que o sujeito barrou, de alguma forma, o lugar do Outro até então absoluto. Nas palavras de Vidal (1999), “está aí a marca de origem do inconsciente como um saber barrado” (p.22).

Freud nos traz a questão acerca da origem dos bebês, mas outras perguntas podem ser contadas como equivalentes simbólicos dessa primeira.

Lembramos, por exemplo, o diálogo mantido por uma criança - de certo, muito inteligente -, com sua mãe após ouvir, numa missa, o padre dizer que a Virgem Santíssima subira aos céus “de corpo e alma”.

Ela diz:

“Mãe, o padre acredita nas coisas que ele fala?”.

Ao que a mãe lhe responde:

"Lógico, se ele não acreditasse, e se não fosse verdade, ele não diria...”

“Mas eu nunca vi alguém subindo pro céu... Como é que se vai pro céu 'de corpo e alma'? E onde fica o céu? Porque não é desse céu, que a gente vê, que ele está falando, é?! Depois que a terra acaba não começam os outros planetas?”

Frente à falta de respostas, nossa criança esboça uma teoria para tentar dar conta de seu enigma.

“Talvez a pessoa tenha um espírito e seja isto o que vai pro céu. Mas corpo, o corpo fica na terra, é enterrado quando morre, não é!? Pode ser ainda que o corpo se pulverize, assim... Que desapareça de repente, como fazem os mágicos, e aí surja numa outra dimensão... Mas não sobe pro céu!”

Como vemos, as respostas obtidas pela criança resultam falhas, sobretudo quando colocam o adulto defronte de sua própria falta em ser, diante de sua própria divisão em relação ao saber. Quando não são evasivas, são repressivas ou ainda mitológicas, gerando decepção e fazendo com que aquela prossiga cada vez mais em sua investigação, só que desta feita de modo velado.

No que diz respeito, mais diretamente, às questões acerca da sexualidade, Freud (1908) coloca que, a partir dessa "primeira decepção, as crianças começam a 
desconfiar dos adultos e a suspeitar que estes lhe escondem algo proibido, passando como resultado a manter em segredo suas investigações posteriores" (p. 217).

Segundo Lemérer (1999), as respostas dadas pelos adultos às questões dirigidas pelas crianças resultam insatisfatórias, por não fazerem outra coisa que rodear e escavar o lugar de uma falta, a falta de resposta que ofereceria ao sujeito o acesso ao saber e ao gozo sexuais.

Resultam insatisfatórias porque quanto mais a criança busca esse saber, mais se defronta com a impossibilidade de saber sobre o sexo, produzindo-se, a cada tentativa de fechamento, um furo de saber.

Para Freud (1908) "essas hesitações e dúvidas tornam-se, entretanto, o protótipo de todo trabalho intelectual posterior aplicado à solução de problemas, tendo esse primeiro fracasso um efeito cerceante sobre todo o futuro da criança" (p.222).

A respeito desse destino cerceador e determinante, que Freud reserva ao trabalho intelectual, a partir das imprecisões e questionamentos colocados para o sujeito acerca do saber do Outro, consideramos necessário lançar um olhar mais acurado. Isto, no sentido de não fecharmos as possíveis saídas que esse sujeito encontraria, por exemplo, ao se submeter a um processo analítico. Senão, o que haveria a dizer de uma criança que apresentasse inibição intelectual? Estaria para sempre fadada ao fracasso?

Ao introduzirmos essa mediação, não estamos discordando de Freud, mas ao contrário, pensamos enfatizar o poder criador e modificador da palavra - poder este, que ele mesmo revelara em sua clínica. Se uma mudança pode se entrever é, justamente, a partir do momento em a palavra pode circular, que o não-dito pode se desvelar, trazendo efeitos que possibilitem ao sujeito um outro posicionamento, uma outra dinâmica.

Desta forma, continuamos nossa digressão, mencionando o texto de Freud (1907), O esclarecimento sexual da criança, onde ele já assinalava os efeitos de verdade que se produzem sobre o sujeito cada vez que algo de seu saber fracassa e que, neste caso, o levarão a sua primeira tentativa de autonomia intelectual a partir da criação das teorias sexuais infantis. 
Quanto a isto, Nobre (1993) acrescenta que na insuficiência de um saber, o desvelamento de uma verdade se impõe, empurrando o sujeito a buscar no Outro, pelas vias da suposição de um saber todo, a resposta que lhe falta.

Assim, segundo Lemérer (1999), as investigações sexuais infantis são efetivamente dirigidas a conquistar o saber proibido de que os adultos supostamente podem desfrutar. Visam o gozo, isto é, a conquista de um saber que viria conjugar o sujeito com seu ser sexuado, o que é impossível.

Entretanto, ao se deparar com esta impossibilidade, a criança se mantém na expectativa de que algum dia este saber lhe seja concedido. E, é o defrontamento com a incompletude do Outro, por sua vez, o que lhe suscitará uma insaciável sede de saber.

Como decorrência desta operação, a atividade intelectual da criança não se limitará somente a corresponder ao desejo do Outro, à imagem esperada pelas figuras parentais, mas, sobretudo, encontrar-se-á agora a serviço do desejo de saber.

Conforme Lacan (1970) menciona ao discutir O poder dos impossíveis: "O efeito de verdade é apenas uma queda de saber. É essa queda que faz produção" (p.178), cujo produto podemos verificar, por exemplo, através das teorias sexuais infantis.

Essas teorias se constituem basicamente na crença das crianças na indiferenciação sexual anatômica, que traz como consequência a atribuição da posse de um pênis tanto para homens como para mulheres; na teoria cloacal, a partir da qual os bebês seriam expelidos como excremento, numa evacuação e, ainda, na crença da concepção sádica do coito.

Segundo Freud (1908), embora essas teorias sejam falsas, "cada uma delas contém um fragmento de verdade". Donde podemos concluir que é dessa articulação entre um saber não-todo com uma verdade - verdade da impossibilidade, do impossível do sexo e, portanto, meia verdade -, que se faz possível que o sujeito prossiga em sua busca de saber e que daí possa, inclusive, vir a produzir conhecimento.

Começa a se perfazer o caminho que marca o sujeito - e lembramos que aqui se trata do sujeito neurótico -, a partir do momento que este é inserido no campo da linguagem e na dialética da castração, e que se constitui na prevalência da ordem 
fálica. O que pode ser visto, principalmente, se recorrermos à primeira teoria articulada pelas crianças, isto é a atribuição de um pênis a todos os seres.

Essa questão se encontra colocada, de modo ainda mais enfático, por Freud (1923) em seu texto A organização genital infantil, ao dizer que "em relação à organização infantil, para ambos os sexos, entra em consideração apenas um órgão genital, ou seja, o masculino". E acrescenta: "O que está presente, portanto, não é a primazia dos órgãos genitais mas uma primazia do falo" (p.180).

É ainda em 1908 que Freud menciona a ameaça de castração, associada neste período à busca de prazer auto-erótico advindo da masturbação, menção que irá se repetir de um modo diferente em seu texto de 1910, Leonardo da Vinci e uma lembrança de sua infância, quando a ameaça de castração se encontrará mais claramente dissociada do órgão genital em si, e relacionada ao caráter de potência fálica que lhe é atribuído.

Freud (1908) situa que, no caso da menina, se estabelece uma equivalência entre pênis e clitóris, sendo este último o que "produz excitabilidade conferindo à atividade sexual da menina um caráter masculino" (p.220).

É importante marcar que a criança, embora já tenha se deparado com a diferenciação sexual, acredita que sua mãe ainda é possuidora de um pênis, o que a impede de concluir satisfatoriamente suas hipóteses acerca da concepção dos bebês.

A este respeito, Freud (1923) descreve que:

Mulheres a quem a criança respeita, como sua mãe, retêm o pênis por longo tempo. Para ela, ser mulher ainda não é sinônimo de não ter pênis. Mais tarde, quando a criança retoma os problemas da origem e nascimento dos bebês e advinha que apenas as mulheres podem dar-lhes nascimento, somente então também a mãe perde seu pênis (p. 183).

Essa questão da dialética fálica, do ter ou não ter o falo permanece, mesmo após a dissolução do complexo de Édipo, como o pivô de toda articulação da sexualidade e, inclusive, no que esta se associa ao interesse pela pesquisa e pelo conhecimento.

Em Leonardo da Vinci e uma lembrança de sua infância, por exemplo, Freud (1910) busca delimitar de que maneira o contato privilegiado de Leonardo com sua 
mãe e seu, provável, empreendimento em investigações sexuais durante a infância, mostraram-se cruciais para o desenvolvimento de sua genialidade artística e científica.

É neste texto precisamente que Freud estreita a questão da sexualidade e da inteligência, o que nos põe na pista de algo que possa se colocar como peculiaridade, ou não, no caso da superdotação. Ele nos diz que:

A pesquisa psicanalítica oferece-nos a explicação completa mostrando que a maioria das crianças, ou pelo menos as mais inteligentes atravessam um período de pesquisas sexuais infantis (Freud, 1910, p. 72 - o grifo é nosso).

Freud (1910) acrescenta que, por ocasião das investigações sexuais, as crianças "já têm uma noção do ato sexual, que lhes parece ser alguma coisa hostil e violenta. Mas como a sua própria constituição sexual ainda não atingiu o ponto de fazer bebês, sua investigação sobre o problema da origem dos bebês acaba também sem solução, sendo finalmente abandonada" (p.73).

Entretanto, haveria ainda nesse processo a transformação das forças psíquicas instintivas, o que possibilitaria à criança se enveredar pelos caminhos do desenvolvimento intelectual, agora por meio de investigações aceitas socialmente. A esta operação Freud denomina sublimação, o que consistiria na "substituição do objetivo imediato da pulsão por outros desprovidos de caráter sexual e que pudessem ser mais altamente valorizados" (p.72).

Neste sentido, cabe-nos citar ainda o que Kupfer (1992) discute acerca da associação da pulsão de saber à pulsão de domínio e à pulsão de ver, ambas citadas por Freud em seu texto.

Kupfer (1992) coloca que, ao final da época do conflito edipiano, parte da investigação sexual cai sob o domínio da repressão, sendo o restante sublimado em pulsão de domínio e pulsão de ver. Enfatiza, ainda, que estas pulsões serão os instrumentos fundamentais para o desenvolvimento intelectual da criança, a partir do momento em que, transformados pela sublimação, manifestam-se no prazer de pesquisar, no interesse pela observação da natureza, no gosto pela leitura, entre outros. 
Sobre a pulsão escópica, Freud (1910) nos diz que ela se encontra atuante antes mesmo que a criança seja dominada pelo complexo de castração, o que a impele a mover sua curiosidade para o orgão sexual materno, que supõe ser um pênis. Segundo Freud, "com a descoberta que fará, mais tarde, de que as mulheres não possuem pênis, este desejo muitas vezes se transforma no seu oposto, dando origem a um sentimento de repulsa...” (p.89).

Freud (1910) situa essa repulsa como a causa futura de casos de impotência ou mesmo de homossexualidade, referindo-se neste ponto à figura masculina.

No entanto, tomamos esse material como um importante fator para analisar os casos de superdotação acompanhados nesta pesquisa, onde o conhecimento surge como uma espécie de objeto tamponador da falta empreendida a partir do defrontamento com castração materna.

Neste processo, vemos que muitas vezes se articula uma atitude reivindicatória ou mesmo de confronto por parte da criança em relação à mãe, sobretudo no caso das meninas. Embora, nos textos abordados até o momento, Freud privilegie a especificidade da estruturação edípica masculina, sabemos que seu direcionamento se modificará ao longo de sua obra. Em textos como A feminilidade de 1923 e a Sexualidade Feminina de 1931, bem como nos estudos lacanianos, obtemos dados que nos permitirão verificar de que maneira a menina também se rebela contra a figura materna a partir da constatação de sua castração. O que a leva, muitas vezes, a se colocar desde uma posição masculina no quadro da sexuação, buscando de alguma forma velar sua falta, sendo este mecanismo bastante presente nos casos de meninas superdotadas.

É já a partir do texto A dissolução do complexo de Édipo, que Freud (1924) começa a introduzir as especificidades no que se refere à organização sexual feminina. Se por um lado, a ausência de um pênis coloca a questão da castração para a menina como um fato consumado, ao passo que para o menino se apresenta a constante ameaça frente à perda do órgão, por outro, não é sem resistências que a menina se defronta com a falta de um pênis.

A renúncia ao pênis não é tolerada pela menina sem alguma tentativa de compensação. Ela desliza - ao longo da linha de uma equação simbólica, poder-se-ia dizer - do pênis para um bebê. Seu complexo de 
Édipo culmina em um desejo, mantido por muito tempo, de receber do pai um bebê como presente - de dar-lhe um filho (Freud, 1924, p.223).

Num trecho seguinte, Freud (1924) coloca que esses "dois desejos - possuir um pênis e um filho - permanecem fortemente catexizados no inconsciente e ajudam a preparar a criatura do sexo feminino para seu papel posterior" (p. 223-4).

Esta citação de Freud permite situar a questão da superdotação a partir de dois viéses distintos. Primeiramente, pelo lado do sujeito superdotado. No caso, a menina, para a qual acrescentaríamos a posse de um conhecimento como um possível substituto do pênis. E, em segundo lugar, fár-se-ia necessário considerar o que está em jogo na dialética do desejo de uma mãe que concebe um filho superdotado, e que o toma de algum modo por objeto suturador de sua falta. Trata-se de uma maneira muito peculiar de afirmar sua supremacia fálica e que, por sua vez, não é sem consequências para a criança.

Freud (1910) circunscreve essa questão ao abordar a relação mãe-criança, dizendo que "sua natureza é a de uma relação amorosa plenamente satisfatória que não somente gratifica todos os desejos mentais, mas também todas as necessidades físicas; e se isto representa uma das formas possíveis da felicidade humana, em parte será devido à possibilidade que oferece de satisfazer, sem reprovação, desejos impulsivos há muito tempo reprimidos e que podem ser considerados como perversos" (p.106).

Cabe acrescentar, que ao usufruto desse amor incondicional corresponde um preço - o de responder também incondicionalmente ao desejo materno.

Este efeito que o desejo materno pode acarretar à criança é passível de ser verificado, por exemplo, ao se abordar a sexualidade de Leonardo da Vinci - análise que Freud tece a partir da proximidade exacerbada de Leonardo com sua mãe -, colocando tal proximidade como um dos possíveis fatores relacionados à privação de sua vida sexual e à dedicação, ainda que platônica, a amores homossexuais.

Anos mais tarde, esse texto de Freud é retomado por Lacan (1957) que aponta, de maneira mais enfática, para o modo como Leonardo pôde se colocar frente ao desejo de uma mãe fálica e como, também sua genialidade, constituiu-se num modo de resposta a este desejo. 
No que se refere ainda à questão da sublimação, cabe-nos retomar o que Freud (1910) acentua ao dizer que essa "transformação da força psíquica instintiva, da mesma maneira que a transformação das forças físicas, não poderia se realizar sem prejuízo" (p.69-70). Esta perda se marca, sobretudo, no que tange à vida sexual do sujeito que, em muitos casos, torna-se extremamente restrita, assumindo um caráter secundário em prol do fator intelectual, o que se encontrava bastante marcante na vida de Leonardo da Vinci, e que também se encontra, de formas variadas, presente na vida dos superdotados.

Tendo em vista o que discutíamos há pouco, acerca da posição da criança frente às figuras parentais, cabe-nos interrogar ainda o que haveria oculto sob o predomínio e exacerbação do desempenho intelectual dos superdotados.

Poder-se-ia levantar a hipótese de haver embutido, nesse processo de recalque da sexualidade, uma carga de amor endereçada à mãe ou ao pai, que não pôde ser devidamente desviada para a escolha de um outro objeto sexual e que, portanto, afasta o sujeito de todo contato com a sexualidade, sob a ameaça de incesto.

Esta suposição parece confirmar-se no caso de Leonardo da Vinci, quando Freud (1910) nos diz que "uma parte muito menor de sua libido continuou orientada para fins sexuais e representa a atrofiada vida sexual do adulto. Porque o amor que tinha pela mãe foi reprimido, essa parte foi levada a tomar uma atitude homossexual e manifestou-se no amor ideal por rapazes. A fixação em sua mãe e nas felizes lembranças de suas relações com ela continuou preservada no inconsciente, permanecendo, porém, inativa por algum tempo. Desse modo, a repressão, a fixação e a sublimação desempenharam sua parte absorvendo as contribuições do instinto sexual para a vida mental de Leonardo” (p.120).

Vejamos, portanto, de que maneira Freud descreve os possíveis caminhos a serem tomados pela pulsão de saber, após caírem sob a repressão sexual, a fim de obtermos mais dados para pensar a questão da superdotação.

Freud (1910) aponta três destinos para o desejo de saber, dentre os quais, abordamos o terceiro tipo ao falarmos do caso de Leonardo da Vinci, e que consiste na sublimação da avidez de saber, da Wissbegierde, que escapa ao recalque, permitindo que a pesquisa intelectual não repita o fracasso das investigações sexuais infantis, já que ela desvia a pesquisa de seu fim sexual. A consequência desse 
processo também pôde ser abordada, isto é, o afastamento dos temas sexuais, seja do conteúdo da pesquisa ou da prática cotidiana do sujeito.

Uma outra possibilidade que se coloca é que o processo investigativo da criança se torne equivalente à sexualidade, devendo como tal ser também recalcado. O desejo de saber permanecerá desde então inibido e a livre atividade da inteligência limitada, talvez para sempre.

Há ainda uma terceira saída possível, isto é, que a atividade intelectual escape ao recalcamento, mas que permaneça secretamente ligada à busca do gozo sexual que era objetivo das primeiras investigações, levando o sujeito a repetir o fracasso experimentado quando da busca de resposta ao enigma de sua existência, empreendendo-se numa busca sem fim de algo que se coloca cada vez mais distante, mas que por outro lado se coloca como o motor de suas pesquisas. Este parece ser um dos destinos adotados em alguns casos de superdotação.

Sublimação, inibição e compulsão seriam, então, as três vicissitudes da Wissbegierde após a repressão sexual.

Diante do levantamento desses dados, consideramos crucial a detenção mais acurada sobre alguns aspectos abordados anteriormente, a fim de vislumbrarmos uma possível leitura acerca dos processos constitutivos que envolvem o "sujeito superdotado".

Para iniciar esta difícil tarefa, propomos a análise de três pontos, a saber: primeiramente, a resposta incondicional do sujeito ao desejo materno. Segundo, a escolha de um objeto sexual e, por último, a sublimação, sobretudo no que esta pode ser relacionada à transgressão.

Tomaremos, como eixo principal para essa articulação, a tese de doutorado de Maria Cristina Kupfer (1990), intitulada “O desejo de saber”.

Quando optamos por enfocar, novamente, a questão da resposta dada pelo sujeito ao desejo do Outro, pretendemos, na verdade, (re)instalar a dimensão do próprio desejo do sujeito, ou ainda, abrir margem para que se conjugue algo de seu gozo.

A esse respeito, é importante situar, por exemplo, a virada conceitual que Lacan (1962-1963) introduz a partir do Seminário da Angústia, ao marcar que se antes o sujeito se referia predominantemente em relação ao desejo do Outro, agora, o cerne de seu questionamento se colocará frente ao que seja o gozo. 
O que pretendemos, em última instância, é apontar para o fato de que se o sujeito permanece numa determinada posição frente ao Outro, isto não se dá sem que haja um ganho. Secundário por suposto, como já assinalava Freud ao longo de sua obra no que se referia ao sintoma, mas, de qualquer forma, tratar-se-ia de um ganho.

Entretanto, há que se perguntar sobre que ganho estamos a falar, uma vez que o sujeito se encontra dividido em relação ao seu saber sendo, portanto, toda impressão e conhecimentos formulados a partir do Eu, parciais, equivocados, dando ao sujeito, paradoxalmente, uma garantia ilusória acerca do que seja ganhar ou perder em termos de subjetividade.

Talvez nesta busca de garantias resida o que é da ordem do gozo, este "termo designado por Lacan (1970) em sentido próprio, que necessita a repetição” (p.43). E que traz à tona os estudos freudianos acerca da pulsão de morte e do objeto perdido. Assim, poder-se-ia dizer que, na verdade, o sujeito se encontra diante de uma perda assinalada a partir da própria operação de castração. A busca por um substituto do primeiro objeto de prazer é o que afirma a dimensão deste objeto como perdido para sempre.

Neste sentido, Lacan (1970) coloca que:

Em função de ser expressamente - e como tal repetido, de ser marcado pela repetição, o que se repete não poderia estar de outro modo, em relação ao que repete, senão em perda. Em perda do que quiserem, em perda de velocidade, de força - há algo que é perda. Freud insiste desde a origem, desde a articulação que estou resumindo aqui, nessa perda - na própria repetição há desperdício de gozo (p.44).

E Lacan prossegue em sua articulação entre repetição e gozo, propondo-se a introduzir uma variante naquilo que anteriormente Freud colocara.

Quanto a isto, ele nos diz: “Aí, tomo do texto de Freud, para dar-lhe um sentido que lá não está apontado, a função do traço unário - quer dizer, da forma mais simples de marca, que é falando propriamente, a origem do significante. E afirmo isto - que não se vê no texto de Freud, mas de modo algum poderia ser descartado, evitado, rejeitado pelo psicanalista -, que é no traço unário que tem origem tudo o que nos interessa, a nós analistas, como saber” (p.44). 
É neste ponto que recorremos a uma questão posta anteriormente por Kupfer (1990) acerca de uma aparente dissonância, colocada por Lacan, entre o que tange ao conceito de saber e de desejo, e que nos impossibilitaria, a princípio, de falarmos da existência de um desejo de saber.

Para iniciarmos essa discussão, partimos, desta feita, do seminário $O$ avesso da psicanálise, no qual Lacan (1970) nos diz literalmente que "o desejo de saber não tem qualquer relação com o saber”. E acrescenta: “a menos, é claro que nos contentemos com a mera lúbrica da transgressão” (p. 21).

Segundo Lacan, os efeitos dessa "distinção radical, tem suas consequências últimas do ponto de vista da pedagogia - o que conduz ao saber não é o desejo de saber. O que conduz ao saber é o discurso da histérica” (p.21).

De que saber Lacan está a falar? Sabemos que ao longo de sua obra o saber se apresenta com duplo sentido, referindo-se ora ao conhecimento e, podendo ser denominado por saberes, como bem o define Kupfer. E, ora sendo relacionado àquilo "que designa o conjunto das determinações que regem a vida do sujeito - um saber, porém que lhe escapa (...). É um saber que escapa ao sujeito no sentido de que ele o ignora. É evidentemente, uma ignorância ambígua, pois incide sobre tudo o que constitui o tecido, o próprio ser do sujeito: o que ele esqueceu de sua história, dos acontecimentos por ele vividos, dos pensamentos e sentimentos que o constituíram e que ainda o constituem. É uma ignorância ativa, uma rejeição: o que ele prefere não saber” (Silvestre, apud Kupfer, 1990, p. 83).

Se considerarmos essa segunda definição, somos levados, num primeiro momento a concordar com o que Lacan coloca acerca do desejo de saber e de sua não relação com o saber, sobretudo se tivermos em conta que o saber presente na pedagogia é da ordem do conhecimento, e, portanto, referido ao campo dos saberes.

Entretanto, se o saber concernente ao inconsciente é o que enreda o sujeito em toda sua história, determinando-o - ainda que este não o saiba conscientemente não estaria este saber também envolvido no ato de apreender, incutido na busca de conhecimento?

Vários estudos e trabalhos foram desenvolvidos visando estabelecer as relações entre um campo e outro do saber. Para Vidal (1999), por exemplo, "a aprendizagem se sustenta na suposição de que o Outro sabe. O Outro é o lugar dos significantes que precedem o sujeito. Um sujeito se constitui a partir dos 
significantes desse corpo”. E conclui: “Aprender é sempre apre(e)nder o significante do Outro; fazer próprias as palavras que formam o tesouro de uma língua” (p.22).

Prossigamos, portanto, em nossa leitura do texto lacaniano para constatarmos que, embora este nos pareça contraditório em alguns momentos, em outros aponta para as questões mesmas que tentamos levantar, sobretudo no que diz respeito à articulação de saber, gozo e conhecimento.

Lacan (1970) coloca que "não há nada em comum entre o sujeito do conhecimento e o sujeito do significante”. E acrescenta: “O significante, então, se articula por representar um sujeito junto a outro significante. É daí que partimos para dar sentido a essa repetição inaugural, na medida em que ela é repetição que visa o gozo” (p. 45).

Trata-se de um gozo proibido, que Lacan insiste em diferenciar da transgressão. Ele nos remete à dimensão do Mehrlust, do mais-de-gozar, que se institui a partir de uma perda de gozo e de um trabalho entrópico do saber a fim de compensar esta perda.

Começa-se a entrever um ponto de consonância, isto porque Lacan descreve que é por meio do mais-de-gozar que podemos distinguir o que se dá no nível "dos saberes harmonizantes que ligam o Umwelt ao Innenwelt” (p.48). Ou seja, o mundo externo ao interno.

Pensamos não só ser possível distinguir o que se passa nos dois campos, como, principalmente, traçar as margens, as balizas a partir das quais se encontram interligados, mutuamente sobredeterminados, lembrando-nos o modelo da banda de Moebius.

É desta suposição, que se depreende que o próprio conhecimento poderia fazer parte desse plus produzido entropicamente, por um saber inconsciente, cujo objetivo seria tentar responder a falta em ser do sujeito.

Corroborando esses dados, Lacan nos diz que “aí está o oco, a hiância, que de saída um certo número de objetos vem certamente preencher, objetos que são, de algum modo, pré-adaptados, feitos para servir de tampão” (p. 48).

O conhecimento neste caso bem se adequa a esta definição de objeto. Tratase, no mundo moderno, de algo veiculado por todos os meios de acesso ao sujeito, sendo considerado uma das fórmulas para se obter sucesso e poder. 
A maneira como as questões referentes à cognição têm sido abordadas na contemporaniedade, realmente não deixa margem para que se possa apreender o que se passa sob o império, sob a prevalência do Eu. Tomado em seu sentido estrito, tratar-se-ia mesmo de um upokeimenon, muito diferente do sujeito dividido da psicanálise. No entanto, se considerarmos o processo na contramão, olhando justamente para aquilo que causaria a necessidade de se produzir um indivíduo deste padrão, um sujeito entificado, veremos que há algo de um outro saber ali presente. Poderíamos dizer, com Lacan, que:

Tal saber é meio de gozo. E quando ele trabalha, repito, o que se produz é entropia, esse ponto de perda, é o único ponto, o único ponto regular por onde temos acesso ao que está em jogo no gozo. Nisto se traduz, se arremata e se motiva o que pertence à incidência do significante no destino do ser falante (p. 48).

E, Lacan conclui dizendo que "isto pouco tem a ver com a fala do ser falante, com sua palavra. Isto tem a ver com a estrutura, que se aparelha. O ser humano, que sem dúvida é assim chamado porque nada mais é que o húmus da linguagem, só tem que se emparelhar, digo, se apalavrar com esse aparelho” (p. 48).

Retomamos aqui o que Vidal (1999) colocava ao falar da aprendizagem e de sua relação ao apre(e)nder da incompletude do Outro, para questionar se não se trataria de um mesmo ponto de estrutura, tal como Lacan o marca acima.

De qualquer forma, faz-se necessário voltarmos ao texto de Kupfer (1990) a fim de precisarmos ainda algumas questões, sobretudo no que diz respeito ao desejo de saber.

Neste trabalho, a autora situa o momento de defrontação da criança em relação ao desejo do Outro não a partir de "um acontecimento fortuito, uma percepção imposta pela realidade, o nascimento de um irmãozinho...” (p. 86). Mas a partir do desejo de ver, da pulsão de ver da qual a criança deveria estar imbuída.

Uma vez colocado esse desejo para a criança, esta se encontraria diante de uma carência, diante de uma ignorância do saber.

Assim, segundo Kupfer, o descobrimento da criança no que se refere à ausência de pênis a leva, normalmente, "a atravessar o complexo de castração, a reconhecer a 'carência' como causa de seu desejo sexual. Mas também a leva a 
reconhecer sua 'carência de saber' como causa do desejo de ver que a levou a descobrir”. Deste modo, ela conclui, citando Claveul, “o desejo de ver e de saber não é estruturalmente distinto do desejo sexual” (p.87).

Como decorrência desta equiparação o que temos é que "o desejo que emerge da operação de castração é um desejo de ver ou de saber, que se transforma em seguida em desejo de nada saber” (p. 87).

E, neste sentido, Lacan (1972-1973) nos diz:

... o inconsciente, não é que o ser pense, como o implica, no entanto, o que dele se diz na ciência tradicional - o inconsciente, é que o ser, falando, goze e, acrescento, não queira saber de mais nada. Acrescento que isto quer dizer - não saber de coisa alguma. (...) não há desejo de saber, esse famoso Wissentrieb que Freud aponta em algum lugar (p.143).

A partir desta premissa, como se sustentariam então as teorias sexuais infantis?

Para Masotta, citado por Kupfer (1990), não haveria coincidência entre o saber, em seu sentido estrito, e o que Freud propõe a respeito da investigação sexual infantil. “A criança, que é um investigador incansável de coisas sexuais, nada quer saber sobre aquilo mesmo que motiva sua investigação: a diferença dos sexos” (p. 89).

... o sujeito nada quer saber (e por isso recalca) sobre a estrutura mesma da pulsão, pois se aceitá-la, terá também de admitir que seu objeto é lábil, indefinível e, portanto inalcançável (Masotta, apud Kupfer, 1990, p. 89).

Deparamo-nos, mais uma vez, com a noção de objeto perdido, o que funda toda labilidade do objeto pulsional.

E, neste sentido, Kupfer aponta na direção do que se marcava no texto freudiano, de 1910, como sendo um furo do conhecimento em relação ao saber, diante do que as investigações sexuais infantis se encontrariam fadadas ao fracasso, uma vez que o objeto procurado jamais seria encontrado. E ainda que o fosse, isto se daria “de modo insatisfatório, incompleto, uma vez que algo sempre estaria sendo 
ocultado, mascarado, em benefício do próprio desejo do sujeito de não saber” (p. 91).

Traça-se, assim, uma disjunção entre saber e desejo, no que tange à leitura lacaniana.

A fim de dar suporte à teoria desenvolvida por Freud em relação à sexualidade infantil, Kupfer recorre novamente à Masotta, dizendo que se verifica no referencial freudiano a presença de "um choque entre desejos: o da criança e o do Outro simbólico, representado pelos pais reais” (p. 90).

Choque ao qual já fazíamos menção, de outro modo, ao dizermos que as respostas dadas pelo adulto à criança não satisfaziam porque, ele mesmo, se encontrava desprovido de um saber sobre o gozo. Uma vez que, ao sujeito, é vedado responder por seu ser sexuado, responder como sujeito do sexo. Trata-se de uma impossibilidade própria da estrutura.

É por isso, por essa falta estruturante que marca o sujeito como sujeito barrado, alienado em relação ao seu saber, que a investigação sexual da criança tenderá a se apagar sob o efeito do recalque, ainda que as questões sobre a sexualidade permaneçam de forma velada.

E, neste enfoque, Cristina Kupfer distingue dois níveis de abordagem do sexual: o primeiro é circunscrito como o referente "às perguntas objetivas sobre a procriação, anatomia, e até sobre relações sexuais. E, o segundo, bem diferente, articulado com as interrogações sobre o sujeito que está implicado em realidades como as da castração, do desejo inconsciente, da diferença dos sexos - todos eles problemas registrados no plano do inconsciente” (p.90). Sendo estes aos quais se refere ao dizer que as crianças nada querem saber a respeito.

Seria importante retomar a noção, colocada primeiramente, referida a um sexual restrito puramente a seu real biológico, pois, falar a partir desse enunciado é característico não só das crianças em suas investigações, como também é pertinente para classificarmos as respostas dadas pelos adultos às perguntas infantis.

E, em última instância, é o que se apresenta no cerne de todo desenvolvimento da ciência, isto é, uma total disjunção entre os campos do saber e da verdade, separação que funda um saber de certo modo absoluto, onisciente sobrepondo-se ao saber divino da religião. Separação sobre a qual repousa, sobre a 
qual se sustenta todo o progresso científico - tema que será mais profundamente discutido no capítulo seguinte desta dissertação.

Mas, recolocando nossa pergunta, se o sujeito nada quer saber acerca da falta, acerca da hiância que o funda, de que maneira podemos explicar seu empreendimento voraz nas questões sobre as origens e sobre a lógica que engendra o mundo e se arvora nas ciências, nas artes, entre outros?

O que estaria, então, implicado nas investigações sexuais infantis e em sua relação à atividade intelectual da criança?

Uma luz sobre esta questão surge a partir dos textos de Piera Aulagner (1967/1980), para quem "todo desejo de saber é um desejo de saber sobre o desejo”.

Desta forma, poder-se-ia dizer que se, num primeiro momento, a criança se descobre objeto do desejo da mãe, num segundo tempo, constatada a castração, o sujeito se depara com o fato de haver um desejo que pré-existia ao seu nascimento e, que, ao mesmo tempo, o transcende na atualidade. Isto é, ele não é o único objeto capaz de responder à falta do Outro, e, pior, não há objeto passível de tal façanha. Sendo esta descoberta o que despertará seu desejo de saber sobre o desejo do Outro e sobre o que fundamenta o seu próprio desejo.

E, neste sentido, vemos que o sujeito não faz outra coisa que confirmar o destino da pulsão, ou seja, o de retorno ao próprio eu.

A partir deste ponto, fazemos nossa a pergunta da autora: “como é possível passar do primeiro desejo, do qual não se quer saber, para o desejo de saber sobre a ordem do mundo?”

Para responder a esta questão, encontramos referência, no texto aulagneriano, à demanda de saber, a qual viria em substituição ao desejo de saber - este inconsciente -, sendo esse o processo atuante nas perguntas articuladas pela criança e envolvido em seu desenvolvimento intelectual.

Sobre esse novo operador que nos é apresentado, Kupfer se detém em sua tese, dizendo:

É justamente porque não pode haver desejo de saber sobre o inconsciente que pode surgir, em seu lugar, uma demanda de saberes constituídos. O desejo não é enunciável, mas uma demanda o é, e o faz veiculando 
esse desejo. A noção de demanda é, então, o nosso x, a ponte que permite a passagem de um desejo de nada saber sobre o desejo inconsciente para um movimento de querer saber tudo sobre a ordem do mundo (p.101).

O que a demanda de saber visa é à dominação sobre o que se apresenta como desconhecido para o sujeito, sobre o que lhe escapa, sendo concernente a um real, que nenhum conhecimento é capaz de abarcar, mas ao qual se oferecem objetos ilusórios que, ao menos momentaneamente, parecem responder ao vazio, mas que logo se revelam insatisfatórios, levando o sujeito a demandar mais, e mais, saber. Trata-se, por isso, de um encontro fortuito, sempre faltoso. O que caracteriza, em grande parte, a busca desenfreada pelo conhecimento, no caso da superdotação, como um sintoma.

Caminho tortuoso onde o sujeito procura, em vão, uma trilha que o permita conciliar-se com a verdade de seu ser, sendo sempre dela, e por ela mesma, desviado.

Uma vez discutidos esses pontos, haveríamos que retomar ainda duas das três questões colocadas, anteriormente, ou seja, sobre a escolha de um objeto sexual e sobre a sublimação.

Pensamos que, de certa forma, ambas se encontram vinculadas, intrinsecamente. No que diz respeito à superdotação, já foi dito, no início deste trabalho, acerca do afastamento da sexualidade empreendido por esses sujeitos. E quando mencionamos sexual, aqui, logicamente damos ênfase ao que é da ordem da sexualidade genital, mas é sabido que, em alguns casos, esse afastamento se estende para os temas sexuais, de um modo mais amplo, ou seja, mesmo no interior das pesquisas intelectuais.

O sexual se constitui, desta forma, como um tema totalmente desconhecido, quando não aterrorizador, para esses sujeitos. A própria prevalência do fator intelectual já aponta para uma tentativa de se resguardar deste contato, ponto no qual a sublimação vem cumprir um papel.

Dito nas palavras de Freud (1910), a partir da sublimação "parte do que seria a pulsão de investigação se sublima em pulsão de saber”, deste processo decorre que há uma divisão entre o material sublimado e aquele que sofre ação do recalque. 
Entendemos ser este conteúdo recalcado o que se refere ao saber sexual, que remete o sujeito a um período de sua constituição, onde ainda não lhe era vedado o acesso ao primeiro objeto de seu amor, e, simultaneamente, ao advento da interdição desse amor.

Kupfer (1990) aborda esse momento dizendo que "o que o sujeito obtém diante de sua demanda de saber é o Nome-do-Pai, a Lei do Pai, o 'não tocarás nesta mulher' - colocado por Freud. Pedindo, ouve não. Eis a face ‘castradora' da Lei que o pai veicula. Eis a ação do recalque sobre as investigações sexuais infantis. Eis o que produz um desejo de nada saber” (p.104).

No entanto, para que o sujeito possa se enveredar no campo do conhecimento, torna-se necessário que ele desvincule seus objetos de pesquisa de qualquer relação com esse saber - causa de horror e provido de conotação incestuosa.

É neste instante que se vê operar o fruto da sublimação, ou seja, a possibilidade de que um movimento trangressivo se articule no sentido de possibilitar ao sujeito se aventurar no campo dos saberes, uma vez tendo subvertido de alguma forma a interdição, imobilizadora, do pai.

Sendo assim, nosso intuito, a partir de então, será o de refletir acerca do fantasma que paira sobre o superdotado, para quem essa questão do saber acompanhado daquilo que ele porta de transgressão -, está posta desde o princípio.

Neste caso, ser superdotado corresponderia, num momento mítico da constituição subjetiva, a ser o objeto tamponador da falta materna e, como tal, merecedor absoluto de seu amor.

Entretanto, uma vez ocorrendo a intervenção do Nome-do-Pai, o sujeito se encontraria dividido. Instituindo-se, como resultado dessa interdição, uma situação bastante complexa, a saber: por um lado o sujeito estaria, de certa forma, resguardado da demanda indeterminada e absoluta do Outro materno, podendo constituir-se como desejante. Por outro, deixaria de ocupar o lugar de exclusividade anterior, tendo que arcar com o sofrimento narcísico que isto lhe inflige. E, ainda - e este é o ponto mais complexo -, conviver com uma marca que lhe remete a todo o momento àquela primeira posição ocupada, colocando-o a mercê da ameaça da fúria paterna. 
Embora, esteja sacramentado o interdito, ao responder como superdotado, o sujeito não deixa de responder a um ideal narcísico. Sua inteligência lhe permite encurtar distâncias entre o que são seus objetivos e os meios para alcançá-lo, ao conferir-lhe uma capacidade de apreensão e leitura do mundo, que cria a ilusão, não só de que seja possível saber acerca do desejo do Outro, como ainda de que seja ele o detentor deste saber. Aparentemente, não havendo limites para sua ação.

Mas, ao mesmo tempo, paradoxalmente, será essa mesma capacidade que o colocará frente a frente com as questões concernentes à vida e à morte, escavandolhe cada vez mais profunda a falta.

Este ideal que é imputado ao sujeito, a princípio pela mãe, se estenderá, posteriormente, para o campo social, no qual também se encontrará presente, sob a esfera do sucesso, o risco de uma perda, de uma represália, de uma punição.

Os efeitos dessa ameaça podem se manifestar, no sujeito, das mais variadas formas: fobias, rituais obsessivos e, mesmo, na impossibilidade de obter êxito usufruindo seu próprio potencial intelectual.

Ainda que haja um mecanismo de transgressão envolvido na busca de conhecimento, a marca da castração estará sempre presente para o neurótico. E, o objeto suposto completá-lo jamais será encontrado, posto que está perdido desde sempre. Assim, mesmo que seja infindável sua demanda de saber, ele nunca esgotará sua busca, pois nada será capaz de satisfazê-lo completamente.

Em suma, saber fazer, saber decodificar os meios de acesso para desvendar mistérios e enigmas que resultam, para a grande maioria das pessoas, inacessíveis, não dá garantias ao sujeito de que possa acertar sempre. E, pior ainda, mais cedo ou mais tarde, ele se descobrirá também vítima de sua própria armadilha. Pois, não é o fato de conhecer que resolverá sua questão acerca do que é ser, do falasser, de sua falta a ser. Para esta questão não há solução. E, prosseguir nessa busca não é outra coisa que uma forma de manter-se vivo.

Reintroduzindo nossa questão acerca do enodamento entre sublimação, transgressão e superdotação, podemos dizer - a partir do acompanhamento de alguns casos - que, para o sujeito, aceitar esse posicionamento ressoa muitas vezes como um assassinato do pai, como a subversão de uma ordem natural, onde a criação não deve superar o criador. 
E quanto a isto, podemos afirmar que mesmo sob a égide da sublimação, os resquícios dessa ameaça não se fazem apagar totalmente, retornando de modo disfarçado, muitas vezes, no sintoma.

Poderíamos concluir dizendo que, transgredir o saber do pai não é sem consequências para o sujeito, resulta numa vivência conflitante entre o que corresponde à autoridade do Outro e o que concerne ao desejo do próprio sujeito. Mais do que coragem requer sacrifício, reconhecimento de que lhe falta algo, nem que seja o saber sobre o modo como lidar com essa angústia. Resulta numa escolha difícil que uma vez empreendida não poderá mais se calar, tendo o sujeito que arcar com seus frutos e com suas perdas.

Trata-se, para finalizar, de tomarmos as palavras de Nietzsche ao dizer que: “O Homem é uma corda, atada entre o animal e o além-do-homem - uma corda sobre um abismo. Perigosa travessia, perigoso a-caminho, perigoso olhar-para-trás, perigoso arrepiar-se e parar...”. 


\title{
3. SUPERDOTAÇÃO: UMA LEITURA PELO AVESSO
}

\author{
“Colocar a questão das alterações da \\ inteligência e do raciocínio significa também \\ perguntar-se sobre a origem e a morte das culturas \\ e, finalmente, sobre o que constitui o homem \\ em sua humanidade”.
}

Bernard Gibelo

Sabemos que nem sempre os discursos se mostram suficientes para a leitura de temas de outra área que não a psicanálise. Se dentro do setting analítico é possível entrever os giros do sujeito desde o momento em que este chega ao consultório, até a histericização de seu discurso e a entrada em análise, quando se trata de tomar um contexto, digamos social, percebemos que a tarefa não é tão tranqüila assim, podendo assumir rumos tão distintos que muitas vezes parecem paradoxais.

Ainda assim, sustentamos a tentativa de problematizar o conceito de superdotação com base nos discursos articulados por Lacan, sobretudo no intuito de articular a questão social que se acrescenta a já discutida questão estrutural, e servindo como mais um dos pilares a dar suporte para o enodamento: real, simbólico e imaginário.

Desta maneira, partimos da formulação que Lacan (1967) nos traz ao dizer que "uma coisa não ex-siste, não começa a atuar senão a partir do momento em que é notadamente nomeada por alguém”, para acrescentarmos, juntamente com Sillitti (1992), que o nomear não se limita a fazer existir o objeto em questão, mas que acarreta ainda as consequências de tal nomeação.

Diríamos que há um preço a se pagar a partir do momento em que se é nomeado, e propomos uma reflexão acerca das condições que envolvem o conceito de superdotação e o modo pelo qual o sujeito se vê enredado ao discurso social à medida que lhe é outorgado o nome de superdotado. 
Para isto, vejamos que lugar Lacan atribui ao social na constituição do sujeito, a partir da leitura do seminário Les non dupes errent onde Lacan (1974) introduz uma variante em relação ao Nome-do-Pai, variante esta que merece ser mais bem analisada naquilo que se encontra associada aos efeitos do social sobre o sujeito, e que se constitui numa sobreposição à função do Nome-do-Pai, de algo que o autor chamou de nomear para: "Eis aqui o que se prefere no ponto da história em que estamos, ao Nome-do-Pai: o ser nomeado para” (Lacan, 1974).

O nomear para se refere a uma função do desejo materno que, à medida que prevalece e passa a ser desempenhada pelo social, aponta para uma mudança de posicionamento do Nome-do-Pai, o que, num primeiro momento, levaria a pensar no enfraquecimento de sua função.

Esse enfraquecimento poderia ser localizado a partir do momento em que se produz um desvio, no qual se vai de uma significação enigmática em relação ao desejo do Outro escrita no $(-\varphi)$ da significação fálica - o que seria produto da intervenção do Nome-do-Pai -, a um nomear para, onde o nomeado se igualaria a sua significação.

No que diz respeito à articulação do social neste campo, Lacan (1974) descreve que "é absolutamente estranho que aí o social tome uma prevalência de nó, e que literalmente faça a trama de tantas existências; é que ele detém este poder de nomear para a ponto de que depois de tudo restitui-se uma ordem, uma ordem que é de ferro”. E acrescenta: “Será este nomear para o signo de uma degenerescência catastrófica?”

O que é possível apreender das palavras de Lacan é que, à medida que o social outorga ao sujeito um nome, uma categoria como a de superdotado, por exemplo, não resta ao sujeito outra saída a não ser responder desse lugar - uma ordem que é de ferro -, ainda que sob o preço de perder sua singularidade.

E não apenas isto, mas seria necessário ainda verificar os efeitos desse processo de nomeação em termos estruturais. 
Neste sentido, a afirmação “sou superdotado" é uma resposta que se coloca pela via da identificação. Uma identificação bruta ao significante que traria duas consequências mais imediatas. A primeira é trabalhada por Colette Soler ${ }^{*}$ ao marcar que, à medida que o sujeito se apresenta alienado à demanda do Outro, desconhece uma verdade da estrutura: ao sujeito lhe falta a ser. E a segunda se refere ao que Lacan (1967) situa ao dizer que na assunção desta identificação a um significante, o que se pretende é a obturação, com eficácia, de uma falta e a recuperação de um gozo, mas de um gozo fora da medida fálica.

A esse respeito, cabe-nos retomar a questão posta por Lacan (1974) acerca da degeneração catastrófica, citada anteriormente, para dizer que se tratava, naquele momento, de situar a substituição do Nome-do-Pai pelo nomear para no nível da forclusão.

Lacan (1974), referindo-se ao nomear para, diz:

O que este traço designa como retorno do Nome-doPai no real, enquanto precisamente o Nome-do-Pai está verworfen, foracluído, recusado, e a título disto ele designa, se esta foraclusão sobre a qual eu disse que ela é o princípio da própria loucura, será este nomear para o signo de uma degeneração catastrófica? (Aula de 19/03/74).

Porge (1998) coloca que “ao opor o nomear para ao Nome-do-Pai, Lacan antecipa a mudança de sentido que ele dá ao Nome-do-Pai em RSI, em 1975: não mais somente o de representar o nome dado ao pai, mas também o nome dado pelo pai, a função nomeante do pai. É esta que verdadeiramente se opõe ao nomear para” (p. 149).

O que é importante notar é que, embora Lacan só formalize essa mudança em 1975, ele já apontava nessa direção em textos como A ciência e a verdade, de 1966, no qual situava a ciência em relação a foraclusão, naquilo que esta se dirigia, mais precisamente, ao do Nome-do-Pai. E ainda em seu seminário $O$ avesso da psicanálise, de 1970, onde, a partir de uma leitura histórica, pode-se apreender de

\footnotetext{
${ }^{*}$ In Seminario del Campo Freudiano en Barcelona, s.d..
} 
que maneira as modificações no discurso do mestre já marcavam o declínio desse Nome-do-Pai enquanto significante mestre.

Analisar esses textos se faz necessário a fim de situarmos de que maneira a ciência se torna a principal representante do discurso social, assumindo a função de nomeação do sujeito no mundo moderno. A seguir, discutiremos o que Lacan (1970) constitui como o discurso do analista, para finalmente situar ambos - o discurso da ciência e o discurso da psicanálise - em relação ao conceito de superdotação.

Em A ciência e a verdade o que Lacan (1966) nos diz é que a ciência se caracterizaria por uma disjunção dos campos da verdade e do saber, e acrescenta que “a prodigiosa fecundidade de nossa ciência deve ser interrogada em sua relação com o seguinte aspecto, no qual a ciência se sustentaria: que, da verdade como causa, ela não quer-saber-de-nada” (p. 889).

É justamente essa disjunção entre verdade e saber que Lemérer (1999) situa como sendo o que permite à ciência se ocupar do que é sexual, porém naquilo que este sexual se encontra reduzido a seu puro real biológico, excluindo-se qualquer implicação de um sujeito.

Vários autores se detiveram no estudo do discurso científico e de sua relação com a subjetividade. Entre eles se encontra Jerusalinsky* que, referindo-se mais especificamente à ciência positiva, coloca que cada ciência visa produzir um conhecimento capaz de responder ao que há de insuportável frente ao não-saber sobre o objeto. "Cada ciência faz seu recorte do objeto e traça uma borda - seja em teoria ou tecnologia - ao redor dele” (p.3).

Trata-se, segundo o autor, de uma tentativa de "constituir uma borda significante destinada a conter o buraco de ignorância”, a responder à emergência de um real que se torna insuportável para esses sujeitos.

O fundamental a se recortar do texto de Jerusalinsky (Op. cit.) diz respeito ao modo como essa borda para o real se compõe, isto é, a partir de significantes que estão situados no discurso de um, ou que estão situados numa fantasmática coletiva, ou seja, nisto que se chama discurso.

O autor nos diz que:

\footnotetext{
*In "Psicanálise: Instituição <> Transmissão” - Documento apresentado pela APPOA, s.d..
} 
O discurso alude a uma fantasmática coletiva, e isto torna permissível que, nesta práxis discursiva, os significantes não signifiquem a mesma coisa para todo mundo (Jerusalinsky, p.3).

Se os significantes se distinguem na esfera do particular, o que se coloca como uma crítica ao discurso da ciência e que traz à tona novamente a questão posta por Lacan acerca da possibilidade de uma degeneração catastrófica, é propriamente o fato deste discurso buscar um suturamento do sujeito a partir de uma universalização dos conceitos e dos instrumentos que produz.

Neste sentido, apontamos para dois níveis em que essa busca de escamoteamento da falta se dá: primeiramente no que se relaciona ao modo como o corpo é concebido pela ciência e, posteriormente, na equivalência que se traça entre sujeito e objeto, a partir da produção de instrumentos que subtraem do sujeito seu saber.

No primeiro caso, Unterberger (1992) descreve o discurso da ciência como sendo uma forma do discurso do mestre, que se caracteriza por produzir um saber no real. Desta forma, o corpo, nesta acepção, é tomado como organismo, distinguindose do corpo afetado pela linguagem e, portanto, do corpo no sentido libidinal. E conclui: “ao obliterar a dimensão do gozo, o corpo é tratado como um cadáver que é objeto de investigação” (p.64).

Como conseqüência mais imediata, vemos que o sujeito se desimplica de seu sintoma. No caso da superdotação, por exemplo, é à medida que esta é considerada como uma herança genética que se anula a responsabilidade do sujeito pelo gozo que "ser superdotado" pode acarretar, não havendo um diálogo com o que esse posicionamento específico traz.

Vê-se articular uma tentativa de pôr em jogo uma outra forma de gozo, tentativa esta que discutiremos retomando as palavras de Alvarez (1994) ao dizer que "o que a ciência impõe a todos é a universalização dos laços sociais a cada vez que, com uma infinidade de objetos de consumo propõe suturar a divisão do sujeito” (p.80).

Para Unterberger (1992) o que se promove a partir desse discurso é a coletivização de uma mesma maneira de gozar, “ali onde a lei não opera para pôr limites, propõem-se normas que funcionam como suplências da lei do sujeito 
articulado ao desejo. Uma intenção de recomendar com uma norma 'para todos', o que não é senão uma particularidade de estrutura e peculiar da posição subjetiva” (p.64).

Corroborando esses dados, pode-se fazer menção ao que Leandro de Lajonquiére (1997) descreve com relação “ao atual espírito (psico) pedagógico hegemônico", isto é, a prevalência de ideais imaginários em relação aos ideais de ordem simbólica.

Nas palavras do autor, esta sobreposição se presentifica no “pedido de complementação narcísica daquele mesmo que o enuncia. Assim, o ideal, em vez de levar embutido um dever ser - uma dívida para com o passado dos homens e das matemáticas (próprio do ideal simbólico) - encena em si mesmo o dever de ser a metade que ao mandante lhe falta para ser de fato, lembrando Freud, o Ego-Ideal” (p.32).

Num outro trecho de Lajonquiére (1997) conclui: “o ideal imaginário veicula um saber mais parecido com a certeza; então, aquele que recebe a injunção de ser, agora, não só sabe o que lhe estão pedindo senão também como é que se faz para ser. À vista disso, esse saber sobre o desejo passa a ser um saber de fato sabido e, portanto, o veiculado acaba se revelando não um desejo mas um voto de gozo” (p.32).

Novamente nos deparamos com uma busca de fechamento, ao mesmo tempo em que algo da história se exclui. Como o próprio Lacan (1966) propunha, eis mais uma característica da ciência, o fato de não ter memória. "Ela esquece as peripécias em que nasce uma vez constituída...” (p.884).

Quem produz a nomeação capaz de impor ao sujeito uma ilusão de tamponamento, no caso da superdotação? Como discutíamos no primeiro capítulo desta dissertação, este tema se encontra referido ao campo da biologia, da pedagogia e da psicologia.

No que tange à psicologia, Lacan (1960) já marcava seu caráter nocivo e, de certo modo, biologizante, no texto Subversão do sujeito e dialética do desejo no inconsciente freudiano, ao dizer que o que a psicologia visa é a unidade do sujeito, neste sentido considerado como indivíduo, sendo sua maneira de abordá-lo relativa a um retorno de um sujeito do conhecimento. Embora, nesse contexto, busque-se a prevalência do psíquico, este é tomado como duplicando o organismo. 
Frente a esta abordagem, Lacan (1960) enfatiza a importância de se verificar o que do conhecimento cada teoria autentica e o que, desse conhecimento autenticado, valida-se como algo de conaturalidade.

Introduzimos neste ponto uma diferença entre o que anteriormente constituía a idéia de um sujeito passivo, do sujeito estímulo-resposta e o que se apresenta atualmente como um reflexo do mundo moderno, ou seja, o sujeito como um sistema de processamento de informação - fruto do cognitivismo -, diríamos: um sujeito mais próximo da idéia de máquina.

Neste sentido, Rivière (citado por Sillitti, 1992) afirma que “a psicologia cognitiva é uma das manifestações mais claras do zeitgeist científico, a organização tecnológica e certos interesses produtivos dominantes”. E, Sillitti (1992) acrescenta que deste lugar o que se apresenta é um sujeito processador, o sujeito programado. “Um sujeito que possa responder ao drama de sua existência com um 'faltam dados'. Frente ao que chamam os 'problemas de organização do sujeito', opõem os 'problemas de organização do conhecimento’” (p.54). Trata-se, nesta vertente, de um sujeito sem falta, na medida em que os dados que lhe faltam no processador podem ser computados a qualquer momento. Eis o dilema vivido pelo superdotado. Não há nessa dinâmica nada que marque ao sujeito a impossibilidade de acesso a um gozo capaz de responder ao que se coloca como falta a ser.

Haveria uma incongruência interna que, sob a promessa de um gozo Outro, põe o sujeito frente a uma falta - não aquela, estruturante, mas a fabricada a partir de objetos que engendram necessidades no lugar do desejo, produtos da ciência - que colocam o sujeito em busca do objeto ideal capaz de suturar-lhe a falta.

Tudo que se produzir como hiância, por essa via, será percebido como impotência pelo sujeito e não como impossibilidade de acesso/conjugação do sujeito ao seu fantasma.

Neste ponto, fazemos nossas as palavras de Sinatra (1994), colocando que é “desde o discurso do mestre que se oculta o que seria o ideal da identidade do significante, a verdade de um sujeito dividido, em relação à sua causa” (p.26).

A este respeito, faz-se necessário, portanto verificar de que maneira a ciência ocupa os discursos trabalhados por Lacan (1970) no seminário $O$ avesso da psicanálise. 
Neste seminário, Lacan (1970) busca distinguir o que está em questão no discurso como uma estrutura, esta colocada por ele como excedente à palavra.

Atribui à linguagem a possibilidade da existência de relações estáveis que ultrapassam o campo das enunciações efetivas. Para isto, articula como estrutura mínima da linguagem, a proposição de quatro termos, a saber, $\mathrm{S}_{1}, \mathrm{~S}_{2}, \$$ e $a$, que giram numa determinada ordem em algo que Lacan denominou quadrípodes e, que originará quatro estruturas, quatro discursos distintos conforme o posicionamento desses termos.

A partir desta proposição, Lacan discute as funções próprias do discurso, dispondo-as nos seguintes esquemas:

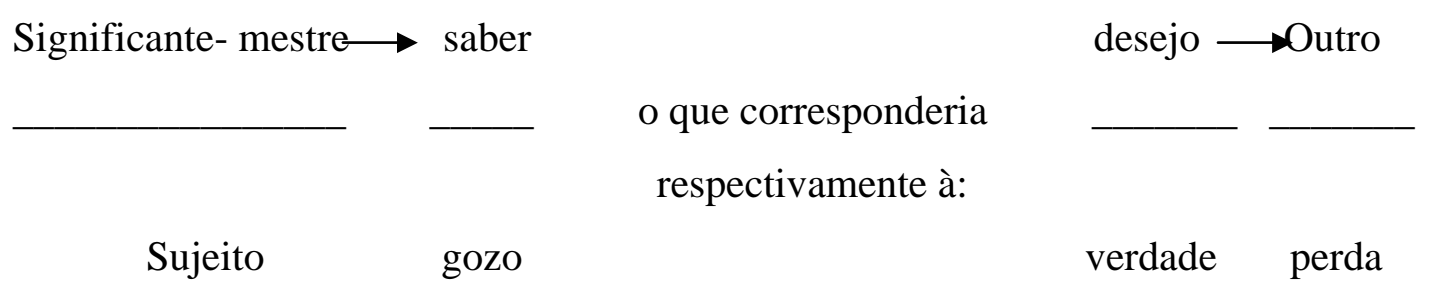

Trata-se da própria estrutura do discurso do mestre, que Lacan marca como sendo aquele que origina os demais - o discurso da histérica, da universidade e do analista -, representando-o por:

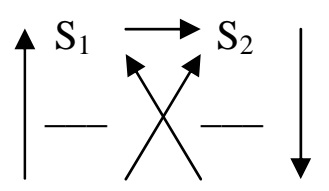

$\$ \quad a$

O que Lacan (1970) circunscreve como sendo o essencial da estrutura é que “é no instante mesmo em que o $S_{1}$ intervém no campo já constituído dos outros significantes $\left(\mathrm{S}_{2}\right)$, na medida em que eles já se articulam entre si como tais, que ao intervir junto a um outro do sistema, surge isto, \$, que é o que chamamos de sujeito como dividido” (p.13). E acrescenta: “Enfim, nós sempre acentuamos que desse trajeto surge alguma coisa definida como uma perda. É isto que designa a letra que se lê como sendo o objeto $a ”($ p.13). 
É justamente nesta operação que Lacan (1970) situa o nascimento da ciência, a partir do momento em que se extraiu da relação entre $S_{1}$ e $S_{2}$ a função do sujeito, feito que ele atribui a Descartes a partir da criação do cogito cartesiano "penso, logo sou”.

Em outras palavras, ao localizarmos a ciência no discurso do mestre, dizemos que ela passa a ocupar o lugar de $S_{1}$, a dominante que faz trabalhar o saber, tendo como efeito um sujeito dividido em relação à verdade como causa. O saber, neste caso, se encontra representado pelo escravo, aquele que sabe sobre o desejo do senhor e que põe a máquina a funcionar. Não fizemos mais que traduzir em matema o que discutíamos até então.

No que se refere especificamente ao saber, Lacan (1970) o descreve como "algo que liga, em uma relação de razão, um significante $S_{1}$ a um outro significante $\mathrm{S}_{2}$ ", fazendo surgir \$. No entanto, ele enfatiza que "é justamente na medida em que tal relação não se sabe, que reside a base do que se sabe” (p.28). Este ponto, já abordado anteriormente por Lacan (1966) em A ciência e a verdade, é o que lhe permite elucidar o que se dá em termos do discurso da ciência no que este vem substituir o lugar do antigo senhor. O que faz o discurso científico? Exime-se da verdade à medida que adota o saber como absoluto, tomando-o na via do conhecimento e, portanto, impedindo que se coloque algo do real em jogo.

O que se evidencia nesse processo, segundo Sinatra (1994), é a estrutura mesma de nossa civilização: “a existência, agora sustentada pelo pensamento cartesiano, deve dar resposta na modernidade, à falta primordial de acordo entre os sexos” (p.25).

Para isto, uma mudança se revela no interior mesmo do discurso do mestre e se verifica na sociedade moderna pelo triunfo do capitalismo, o que é demonstrado através da produção de bens de consumo, que rapidamente cobrem os mercados internacionais, mais além de nacionalidades, línguas e ideologias. Contribuindo ainda mais para colocar o sujeito na categoria de objeto.

Alguma coisa mudou no discurso do mestre a partir de certo momento da história (...). A partir de certo dia, o mais-de-gozar se conta, se contabiliza, se totaliza. Aí começa o que se chama de acumulação de capital (Lacan, 1970, p.169). 
Neste sentido, Sinatra (1994) descreve o mais de gozar como a resultante do recobrimento de dois mercados: o mercado da produção e o mercado do saber. Haveria a produção de um gozo do saber que se cotizaria no mercado - produção entrópica de gozo -, já que o gozo adequado à complementação dos sexos não existe. Como consequência da falta em gozar se elabora um plus, excesso a respeito do que não há, mas defeito a respeito do gozo pretendido por cada um.

O discurso do mestre, segundo o mesmo autor, ocultaria a verdade do processo, "seu efeito de divisão subjetiva - e a produção desse mais de gozar que se desprende desse trabalho do saber - saber que no escravo se punha a funcionar a partir da ordem do amo” (p.26).

Essa mudança no discurso do mestre acarreta consequências que se fazem perceber no nível do saber e desencadeia a formulação de dois outros discursos o da universidade e o do capitalista.

No caso do discurso universitário dá-se a substituição de algo que se colocava no discurso do mestre como um não-saber-de-tudo, por algo que agora se constitui como um tudo-saber.

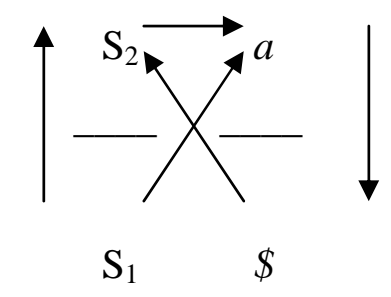

A esse respeito, Lacan (1970) descreve que, no discurso da universidade, o tudo-saber passa para o lugar do senhor e no lugar da verdade o que se tem é um significante de senhor.

Trata-se de um saber absoluto que em muito se vê articulado no discurso pedagógico e psicológico, dos quais resulta toda gama de enaltecimento e equívocos acerca do sujeito superdotado, que é idealizado como aquele capaz de, imaginariamente, complementar o professor em sua falta.

“A verdade deve ser produzida pelos que substituem o antigo escravo, isto é, pelos que são eles próprios produtos, como se diz, consumíveis tanto quanto os 
outros. Sociedade de consumo, dizem por aí. Material humano...” (Lacan, 1970, p.30).

Desta forma, o discurso da universidade é o que mais se assemelha ao sistema econômico e cientiífico, vigente na contemporaniedade.

Lacan (1970) nos diz ainda que, neste discurso, o proletariado é despossuído de seu saber, é frustrado pela exploração capitalista que o torna inútil. O que lhe é devolvido, em uma espécie de subversão, é outra coisa - um saber de senhor.

Análoga à situação do proletariado é a condição do aluno. O discurso da universidade, como dizíamos, é o que mais se aproxima do discurso científico, e é justamente nele onde o aluno passa à condição de objeto.

Poder-se-ia dizer que aquilo que se colocava anteriormente como seu saberfazer se reverte na tentativa de reproduzir o saber de senhor, agora representado, sobretudo pelo técnico, despersonalizado sob o discurso da psicologia e da psicopedagogia principalmente.

Reproduzir o que o discurso moderno impõe, significa obter o melhor desempenho possível nas atividades propostas, nos concursos, testes, entre outros, a fim de alcançar o maior êxito possível, com menor dispêndio de tempo e de gastos no que o superdotado vem atender plenamente a demanda.

Lacan (1970) descreve que "o escravo sabe muitas coisas, mas o que sabe muito mais ainda é o que o senhor quer, mesmo que este não o saiba" (p.30). A partir desta citação, interrogamos como o sujeito, ao ser tomado como objeto de investigação, pelo saber científico representado no discurso universitário, responde ao desejo do senhor.

Para responder a esta questão, consideramos ilustrativo recorrer ao que Lacan (1972-1973) dispõe no seminário Mais, ainda, em o Rato no labirinto.

Neste texto Lacan se questiona acerca do que seria o aprender. Ele prossegue dizendo: "trata-se de um rato num labirinto que reconhece alguns traços luminosos a fim de conseguir comida. O labirinto não termina apenas na comida, mas num botão, ou num trinco, do qual é preciso que o sujeito suposto desse ser, (o rato) encontre o truque pelo qual aceder à sua comida. Ou ainda, trata-se do reconhecimento de um traço luminoso ou traço de cor, ao qual o ser é suscetível de reagir... A questão que só é colocada secundariamente, e que é a que me interessa, é a de saber se a unidade ratoeira vai aprender a aprender. É aí que vige a verdadeira mola da experiência... 
Nada confirma que possa haver no rato sacação do mecanismo ao qual resulta apertar o botão" (p.191-2).

Lacan segue se questionando se o ser do rato pode aprender algo aí.

Dito de outra forma, esta é nossa questão no que se relaciona ao aprendizado do aluno, e também do superdotado, em relação ao mestre moderno, ou seja, este aluno que responde prontamente ao que lhe é demandado em termos de desempenho é capaz de aprender, ou somente reproduz mecanicamente os conteúdos, sem refletilos ou elaborá-los a partir de sua própria experiência?

A resposta para esta questão talvez possa ser encontrada num texto de Neme (1999) no qual a autora retoma a questão de Lacan no Seminário XX, dizendo que o que poderíamos supor nesse rato é um mínimo de subjetividade já que responde a um signo - o que representa algo para alguém -, mas não se trataria de aprendizado.

Neme (1999) enfatiza que, para aprender, supõe-se que algo foi apreendido num primeiro tempo. "Não há nada que nos indique que o ser do rato sofreu um atravessamento. Aprender quer dizer 'tomar posse de'. O que o sujeito toma do Outro em última instância é a castração, o aprender a aprender fica reservado ao ser falante já que este toma para si o que recebeu do campo do Outro, e esta passagem tem a castração como condição" (p.45).

Se no caso do superdotado este atravessamento ocorreu pela via da castração, podemos dizer que a capacidade de aprender exista, mas que esteja inibida, dado o grau de alienação desse sujeito em relação ao Outro, tomado talvez neste momento como absoluto e, portanto, como não faltante. O que, por sua vez, outorga a esse sujeito a ilusão de uma completude possível. O que dizer de um sujeito que se vê nomeado como superdotado? Este nome em si já o fecha, não deixando margem para que qualquer hiância se apresente, pressupõe um sujeito perfeito.

Alvarez (1994) é um dos autores que se dispõe a investigar temas como esses, cuja denominação os fecha em si mesmos, os quais são chamados por ele de fenômenos do mundo moderno. A esse respeito, o autor nos diz que "se o sujeito se afirma como 'eu sou', correlativo a um 'eu não penso', como rechaço do inconsciente, reduz-se assim a distância entre o corpo como deserto de gozo e o gozo como fora do corpo" (p.82).

Sabemos que Lacan, em diversos momentos de sua obra, ao fazer menção ao cogito cartesiano "Penso, logo sou", buscava marcar, entre outras coisas, de que 
maneira essa proposição caracterizava a própria condição do sujeito como sujeito dividido. Suprimir o pensar desta operação suporia não só uma ilusão de suturamento, quanto colocaria o sujeito em condição de objeto pronto a se consumir pelo aparato capitalista.

Caberia, neste contexto, examinar mais de perto o que se dá como resultado ainda da transformação do discurso do mestre, e que Lacan (1972) apresenta como sendo o discurso do capitalista.

Este seria caracterizado, segundo Alvarez (1994), “fundamentalmente por uma circularidade que afetaria seus quatro termos e que, entre outras coisas, teria como efeito uma reabsorção contínua de todos os objetos produzidos pelo saber, um discurso, portanto, em que seria possível a relação sexual” (p.80).

Nas palavras de Tarrab (1992), “um discurso no qual um sujeito em sua falta de gozo estrutural, demanda ao saber científico a produção de um objeto capaz de um gozo que, sem consequências, venha a suturar sua castração, sua divisão, sua miséria...” (p.41).

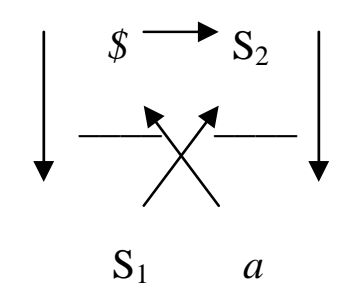

Lacan abandona posteriormente este matema, justamente por ele não cumprir a condição essencial para ser considerado um discurso, isto é, por nele não existir lugar para a falta, constituindo, portanto, um falso discurso.

Embora seja falso, Alvarez (1994) lembra que isto não impede que o mesmo seja sustentado como uma ilusão pelo discurso do mestre, sobretudo naquilo que este se faz representar pela ciência.

Além disso, Lacan (1972) coloca que essa pequena inversão entre o $\mathrm{S}_{1}$ e o \$ que é o sujeito é o que basta para que as coisas se ponham a marchar sobre rodas no discurso do capitalista - atendendo ao que seria o desejo do mestre antigo "que as coisas andem”. E acrescenta: 
Não poderia marchar melhor. Porém justamente isso marcha demasiado rápido, isso se consome, se consome tão bem que (literalmente) se consome (Lacan, 1972, p. 9).

Nisto reside o fato de ser considerado por Lacan como o mais astuto dos discursos e, ao mesmo tempo, como aquele que não se sustenta, como o que está “consagrado a arrebentar” (p.9).

Caberia perguntar como os efeitos desses discursos se fazem representar no caso da superdotação, mais especificamente no que concerne a este ato de nomeação proferido pela ciência em suas diferentes roupagens e reproduzido em grande parte pelos órgãos de ensino.

Para isto, retomemos a questão da identificação ao significante para dizer que, no caso do superdotado, esta identificação supõe um gozo e um nome para esse gozo, não um sujeito.

O sujeito se encontra alienado, não só ao Outro do significante e do desejo, ao qual se supõe um saber, como inconsciente. Trata-se também da alienação a um significante produzido pelo Outro social - seja este Outro representado pelas teorias psicopedagógicas ou pelas próprias leis do mercado -, e que vem no lugar do ponto de ruptura do sujeito em sua economia subjetiva, em sua relação ao Outro.

Segundo Unterberger (1992), trata-se de um ser fabricado pelo Outro da ciência, sendo neste sentido que se situa "os momentos limites da submersão no gozo como o ponto de onde o sujeito, forcluído do discurso, fazendo-se resto, faz-se idêntico ao objeto" (p.65).

Dito de outro modo, àquilo que o sujeito traz como marca estrutural vem se associar uma demanda social, totalizante. No lugar de algo que se punha como fenda, sobrepõe-se uma ilusão, possibilidade de reparação.

Se do lado do sujeito havia a busca de um suturamento, vem se conciliar a essa busca um objeto ou título que sirva de invólucro ao sujeito, tendo como meta resguardá-lo do contato com sua ferida narcísica.

Na prática, esse mecanismo pode ser verificado através da busca desenfreada, por parte de instituições de ensino, no exterior e no Brasil, de alunos com nível de inteligência superior a média. 
Para esta seleção, fazem uso não só dos já conhecidos testes de nível intelectual - aplicados na ocasião do ingresso desses alunos na escola -, como ainda dispõem de diversas atividades, desenvolvidas no decorrer da história escolar, a fim de estimular a competição e localizar aqueles que se destacam como os mais inteligentes.

Buscam as melhores cabeças, mais um número em meio à multidão. Um número que, neste caso, se representa por um Q.I., e que enaltece a escola, responde ao narcisismo parental, mas que não fala do sujeito. Parafraseando Lacan (1966) "uma verdade que fala tem pouca coisa em comum com um número que, desde que a razão pura se lembra, fecha-a" (p. 883).

A partir deste fechamento, o sujeito se encontra totalmente presa de um discurso alienante, que não lhe deixa saída, isto porque, conforme já dizia Lacan (1954-1955) acerca do medium de noções difusas, culturalmente admitidas, cria-se uma ilusão de que esses atributos "sejam oriundos de uma propensão natural, quando, no entanto, no atual estado da civilização, são designados, de fato, por todos os lados" (p.11).

Neste contexto, em que consistirá o discurso do analista e qual será sua função?

Tratar-se-á de um discurso que terá por meta promover a histerização dos demais discursos e apontar para o impossível da relação sexual.

Um discurso que nos permitirá dizer, retomando a fala de Freud (citado por Lacan, 1954-1955), que "o sujeito não é a sua inteligência, não está no mesmo eixo, é excêntrico. O sujeito como tal é algo diferente de um organismo que se adapta. É outra coisa, e para quem sabe ouvi-lo, a sua conduta toda fala a partir de um outro lugar que não o deste eixo que podemos apreender quando o consideramos como função no indivíduo...” (p.16).

Trata-se de um discurso que se representa pelo matema:

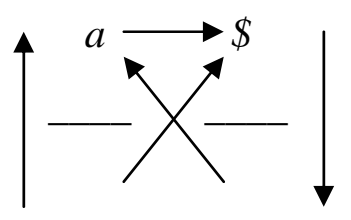

$\mathrm{S}_{2} \quad \mathrm{~S}_{1}$ 
Nas palavras de Vidal (1999) “a contribuição específica da psicanálise aos outros discursos consiste em manter a hiância do impossível, fazendo obstáculo ao fechamento imposto pela demanda totalizante do corpo social (...). A psicanálise dá um lugar ao mal-estar na cultura, com irrupção no laço social do real que foi excluído do simbólico. A psicanálise faz função de um real que cada discurso à sua maneira, denega ou desmente” (p.25).

O discurso analítico pode produzir efeitos sobre o discurso da ciência, ao introduzir, por menor que seja, uma questão sobre um assunto tido como fechado e sacralizado, como é o caso da superdotação. Nosso direcionamento se dará justamente no sentido de apontar para aquilo que nesse campo não faz esfera.

Se pelo lado da ciência, o que se busca é esse Um-tudo, esse Um unificante do qual Lacan (1970) nos fala - pela via do mais inteligente, do mais adulto, do que sabe tudo, do mais adequado ao mercado, do perfeito -, a psicanálise, por sua vez, vem marcar a diferença, vem abrir espaço para a singularidade e para o desejo do sujeito - o que possibilita inclusive que se tome conhecimento do sofrimento que se coloca para esses sujeitos.

Porque não se trata de outra coisa além de um sofrimento. Todo empreendimento do sujeito por uma busca de recobrimento, só faz reforçar sua condição de sujeito divido. Sofrimento que se inicia num tempo remoto da constituição subjetiva e, que Freud situa a partir da constatação da falta de pênis na mãe e da natureza assumida pelo falo desde então.

Lacan (1966) retoma esta questão, dizendo que "o sujeito divide-se ali (...), ao mesmo tempo vendo abrir-se o abismo contra o qual se protegerá com uma fobia, e, por outro lado, cobrindo-o com a superfície que erigirá o fetiche, isto é, a existência do pênis como mantida, ainda que deslocada” (p.892).

E, conclui: "De um lado, extraiamos o (nada-de) do (nada-de-pênis), a ser posto entre parêntese, para transferi-lo para o nada de saber, que é a não-hesitação da neurose. Do outro, reconheçamos a eficácia do sujeito nesse gnômon que ele erige para lhe apontar a toda hora o ponto da verdade. Revelando, do próprio falo, que ele nada é além desse ponto de falta que ele indica no sujeito” (1966, p. 892).

Retomando o Seminário XVII, pensamos que abordar a superdotação pelo avesso, seja a possibilidade de se introduzir uma questão e de se fazer, parafraseando Lacan (1970), sulcos na aletosfera. Isto é, abrir uma fenda na verdade fechada que a 
ciência propõe e abrir espaço para que uma outra verdade possa se colocar, a partir da escuta do sujeito. O que nos propomos a fazer no próximo capítulo. 


\section{APRESENTAÇÃO DOS CASOS}

"Sou como um caminho noturno, que escuta em silêncio os passos de suas recordações”.

Tagore

Passemos à apresentação e discussão dos casos acompanhados nesta pesquisa, a partir dos quais, visamos demonstrar de que maneira a superdotação surge como um sintoma, direcionado a responder ao fantasma parental, sobretudo, naquilo que este se relaciona ao desejo materno. Para isto, utilizaremos uma leitura analítica, visando alcançar uma outra dimensão, para além do discurso comum e consciente. Retomando as palavras de Lacan (1957), sabemos que:

No discurso sustentado por um sujeito, há algo que ultrapassa seu querer. O paradoxo, o imprevisto, o acidente produzem significantes que se engatam e geram efeitos de sentido. É aí que fica em jogo uma verdade num nível diferente do eu do sujeito. Há alguma coisa que funciona no inconsciente mais além do par formado pelo eu e o outro, trata-se de uma entidade estrutural.

Sendo assim, apresentaremos dois casos, coletados por meio de entrevistas abertas, com as crianças e com seus pais, separadamente. Iniciando a primeira dessas leituras com o caso Soledad: um desejo de infância, no qual veremos como ser superdotado se constitui, para ela, numa forma de atender ao desejo de infância da mãe, ao mesmo tempo, que se lhe imputa, para isto, a perda de sua própria infância, da qual Soledad se torna desejante.

A seguir, em Narciso: quando o desejo é de morte, veremos de que maneira responder ao desejo do Outro materno pode se constituir num total apagamento do sujeito sob a fala da mãe. 


\subsection{Soledad: um desejo de infância}

- "Eu diria que eu perdi o meu lado criança muito cedo...”

Soledad é uma garota de onze anos que foi diagnosticada aos três como superdotada.

É durante entrevista com seus pais que vai se delimitando em que ponto a superdotação, neste caso, pode ser relacionada a uma operação da linguagem, a uma operação significante.

Quando é perguntado à mãe sobre suas expectativas acerca do nascimento de Soledad, ela diz: “... desde que eu era criança, sempre quando pensava em ter filho, eu falava que seriam dois e um deles seria superdotado. Não sei se por sugestão ela veio ou se eu estava intuindo alguma coisa”.

A partir desta fala, marca-se um papel importante do desejo da mãe na constituição psíquica de Soledad. Superdotado neste contexto pode ser pensado como um traço unário, como o $S_{1}$ - aquele que tem seu significado como efração do desejo materno, encontrando-se metaforizado pelo Nome-do-Pai. $\mathrm{S}_{1}$ em torno do qual o sujeito articula a cadeia significante e que o marca como \$ barrado, dividido em relação à verdade que o causa, colocando-o na busca do recobrimento de uma falta. Falta que se presentifica nessa busca mesmo. Sendo a partir desse significante - superdotado - que Soledad se coloca como um, passando a contar sua história sem saber de que desejo ela é efeito.

Soledad é a primeira filha do casal, uma filha que desde o início se antecipou, o pai "queria que fosse um filho, perfeito e com saúde. Esperava que viesse em cinco anos e não em cinco meses”. E, conclui: “a gente tinha uma previsão e ela se adiantou”.

Uma filha que vem no lugar de um filho. Esta também é a fala da mãe: “eu estava esperando um menino, aí veio menina, veio a Soledad. Aí tive aquela coisa de aceitação, tal...”

Embora Soledad tenha decepcionado os pais, por um lado, arrumou um jeito de responder ao desejo de infância da mãe - pela via da superdotação -, e, a partir daí, também ao desejo paterno como o "filho perfeito". Ao nos aprofundarmos no 
caso, veremos que se colocar nesse lugar é responder a partir de uma posição masculina.

Revela-se, então, para Soledad um não-saber que a põe a trabalhar, parafraseando Aulagner (1967), “o seu desejo de saber sobre o desejo do Outro”.

Soledad começa a dirigir aos pais os mais variados tipos de perguntas, que logo se transformam em indagações acerca da sexualidade.

Devido a esse posicionamento de Soledad, seus pais começam desde muito cedo a encará-la de um outro modo. Um modo talvez que os preservasse mais do confronto com suas próprias questões sexuais. A mãe nos diz: “eu nunca consegui ver Soledad como uma criança, principalmente depois de eu saber que ela era superdotada. E até depois, quando ela nos fazia pergunta sobre sexo, quando ela fazia esse tipo de pergunta. Então, eu sempre falei mais do que devia...” Ao que o pai complementa: "quando a gente não tem coragem de dizer, até hoje, a gente compra alguma literatura específica daquele assunto, depois lê e tira as dúvidas”.

É interessante observar o discurso do pai neste momento, pois embora ele pretendesse se referir a Soledad quando nos diz que “depois lê e tira as dúvidas”, se tomarmos sua fala "ao pé da letra”, vemos que não se sabe quem duvida mais, se Soledad ou se seus pais.

Algo nessa linha, já se manifestara anteriormente, quando falam sobre a primeira vez que foram chamados a olhar para a diferença intelectual de Soledad, ou seja, no momento em que procuram um médico para tratá-los... Mas, tratar de quem?

O pai relata: "Eu lembro perfeitamente da primeira vez que alguém falou pra gente que Soledad era diferente. Foi quando a gente foi nesse médico, amigo nosso. Nós não fomos levar a Soledad exclusivo pra uma consulta, ela nos acompanhou, não é?! Nesse dia, eu nem sei quem foi se consultar...” E a mãe completa: “ou fui eu, ou foi você".

Este extrato confirma nossos indícios anteriores de que o sintoma de Soledad encontrar-se-ia associado, como uma resposta ao fantasma parental.

Podemos verificar, ainda, que embora os pais de Soledad tenham se esforçado em lhe dar respostas, sobretudo científicas acerca das questões sexuais, como já era de se esperar, a partir de uma leitura freudiana, estas resultaram insatisfatórias. Como decorrência deste processo, dessa primeira decepção, Soledad articula sua primeira 
tentativa de independência intelectual, passando a contestar toda e qualquer colocação de seus pais. Vejamos o que estes têm a falar a este respeito:

Mãe: "Ela é muito questionadora, ela questiona demais. Ela jamais aceita que uma coisa é não - ‘Por que é não?'. Com ela é muito difícil, ela nunca aceita nada”.

Pai: “Tem que conversar... E, muitas vezes, tem que ser autoritário”.

Mãe: Aí ela vira e vai embora. Daqui a pouco, ela volta com o mesmo assunto, ela não desiste nunca”.

E o pai conclui: "Daqui a dois/três dias, ela retoma o assunto até conseguir".

Comecemos, portanto, a analisar a maneira como Soledad se posiciona frente à superdotação e o modo como esta se articula à sexualidade.

Para Soledad a superdotação começou a lhe fazer questão a partir do nascimento de seu irmão, quando tinha por volta de três anos.

S.: "Quando o meu irmão nasceu, eu fiquei parece com muito ciúme, aí minha mãe me levou pra fazer o teste, porque tinha essa suspeita. Aí eu fiz e deu que eu era superdotada. Foi isso, acho que foi assim”.

An.: "Você falou que já tinha uma suspeita..."

S.: "É. Não sei, não lembro. Realmente eu não sei o que eu fazia. Porque a pré-escola que suspeitou e falou pra fazer o teste. Aí depois, eu não sei por que a minha mãe me levou pra fazer isso, eu não sei”.

Soledad fala de uma suspeita, uma suspeita que bem poderia dizer respeito a um saber sobre o lugar que lhe estava reservado desde a infância da mãe.

Além disso, Soledad queixa-se, ainda, de não saber por que a mãe a leva "pra fazer isso”. Como diria Mannoni (1984) "sem o saber, ela é levada a cumprir o voto inconsciente da mãe”.

Dito de outro modo por Lacan (1954) "existe sempre na mãe, ao lado da criança, a exigência do falo, que a criança simboliza ou realiza mais ou menos. Já a criança, que tem sua relação com a mãe, não sabe nada disso. Para a mãe, a criança está longe de ser apenas a criança, já que ela também é o falo” (p.56).

E, neste ponto, vemos se perfilar o que da sexualidade materna encontra-se imbutido nesta dialética, e o quanto Soledad responde a esta demanda ao se colocar como falo da mãe e assumir a posição masculina, abdicando, para isto, inclusive de sua infância. 
S.: "Eu diria que eu perdi o meu lado criança muito cedo... Eu sempre falo que eu queria ter brincado... Eu não curti minha infância. Acho que eu fui criança, que brinquei de boneca até três anos de idade. Então, eu não queria mais ser criancinha de brincar com boneca, ser tão inocente assim”.

Algo de emergente se coloca para Soledad a partir dos três anos: a chegada do irmão e, com ela, as questões sobre as origens, sobre o desejo do qual ela mesma nasceu. O defrontamento com a diferença sexual - com o ser castrada -, “ele tem, eu não". Consequentemente, coloca-se também a possibilidade de vir a cair do lugar que lhe fora determinado anteriormente.

A mãe de Soledad situa este momento, da vinda do segundo filho, dizendo: “quando veio o menino, como a gente não tratava ela como criança e nunca conseguiu ver ela como criança, foi muito difícil, porque aí eu fui ver que ele falava errado, tinha aquela coisa de bebezão mesmo, diferente dela. Então ela perguntava: 'Por que ele veio?' Gerou muita coisa de ciúme... Ela corria na frente, respondia as coisas por ele... Ela é apressada pra tudo”.

Soledad continua falando de como foi a experiência da chegada do irmão.

S.: “Quando o meu irmão nasceu eu já era ciumenta, sempre foi assim. Aquela coisa de filha única, toda a paparicação pra você e tal, de repente nasce um..., uma pessoa que vem do nada, você não sabe de onde veio e, e, e tem que dividir a sua atenção com ele... era horrível”.

Responder como superdotada, a partir desse momento, surge como uma tentativa de sustentar um lugar específico no desejo materno e, ao mesmo tempo, como uma defesa frente à constatação da falta do Outro e de sua própria condição de sujeito faltante.

S.: "Se eu sou superdotada, se eu sou mais inteligente, eu tenho obrigação de ser melhor do que ele (referindo-se ao irmão), de ser melhor, de ser melhor, pelo menos não em tudo, mas na maioria das coisas, que os outros... Daí veio essa coisa de ser sempre a melhor”.

Soledad passa a buscar aceitação do Outro por meio de seu desempenho escolar, no entanto, é neste instante que começa a se colocar diante do preconceito daqueles que ela chama de normais, e que a excluem por saber demais. Sua meta passa a ser "não errar”. Mas se isto a aproxima do ideal parental, a afasta do convívio com seus colegas. Diríamos que a falta não deixa de se escrever a todo o 
momento, precipitando Soledad cada vez mais a tentar suturá-la, estabelecendo-se uma repetição e gozo constantes.

Nota-se muita dificuldade, de sua parte, em se deparar com a carência do Outro, uma vez que isto seria admitir sua própria incompletude. Por vezes, reforça este Outro, sustentando-o como absoluto ditador de regras, as quais aplica ou cita em diferentes momentos da entrevista onde se perfaz a possibilidade de que algo de hiância venha a se colocar.

An.: "Ser superdotada marcou de alguma forma a sua vida?"

S.: "Não. Acho que não. Não tem que ter diferenciação porque a pessoa é inteligente ou não. Acho que não tem, não sinto que tem... Acho que você não pode aproveitar disso de uma forma errada e sim aproveitar de uma forma certa. Porque se você aproveitar de uma forma errada, quando você realmente quiser aproveitar de uma forma certa, você não vai poder aproveitar”.

An.: “O que seria 'aproveitar de uma forma errada'?”

S.: "De uma forma errada é você se impor por causa disto. Tem pessoas que não gostam de se expor assim. Eu, assim, acho que eu não tive. Mais ou menos assim... Agora não, mas quando eu era menor, eu tive medo de errar, porque normalmente eu acertava, aí quando eu errava já dava aquela coisa assim... Acho que essa coisa de não poder errar é aproveitar de uma forma errada. Tem que ter consciência de que pode errar e que você tem que errar pra aprender, ninguém nasceu sabendo. Talvez eu tenha mais facilidade, mas ninguém nasceu sabendo.

An.: "Ninguém nasceu sabendo..."

S.: Assim, tem aquele ditado que todo mundo fala que ninguém nasceu sabendo...

Soledad novamente se coloca a partir de um mandato do Outro, não se apropria de sua fala, sempre que é convocada a se responsabilizar, a se implicar no que fala esquiva-se, recua, remete-se a um terceiro.

Vemos também, neste trecho da entrevista que, para Soledad, responder do lugar de superdotada é se expor e, se expor, sobretudo ao risco de errar, o que para ela é difícil, uma vez que se encontra tomada por esse Outro demandante de seu papel.

Nessa dialética, ela bascula de um extremo ao outro, partindo de um imperativo de que "não se pode errar" ao imperativo de que "só se aprende errando". Além disso, o fato de se remeter ao ditado "ninguém nasceu sabendo", 
como um modo de se defender da possibilidade de errar, também aponta para uma questão acerca da diferença. Diríamos que se coloca para ela um enigma diante de sua própria condição frente ao saber. Ninguém nasceu sabendo, mas ela tem mais facilidade, o que acaba por diferenciá-la, extraí-la desse padrão que se põe como regra para os demais. Evoca-se algo de horror, naquilo que esse horror concerne ao real e, portanto, insuportável. Ela é diferente. O que essa diferença representa para Soledad?

Poder-se-ia falar dos efeitos de uma operação transgressiva, concernente ao próprio mecanismo de sublimação, tal como discutíamos no terceiro capítulo desta dissertação? Transgressão que marcaria uma certa subversão, negação do saber do pai e de sua interdição ao desejo materno, que surgiria como uma das condições necessárias ao desenvolvimento intelectual do sujeito, ainda que lhe deixe a sombra de uma ameaça de castigo paterno?

Continuo chamando Soledad, para que se implique no que diz, retomando sua fala a respeito de "ninguém nasceu sabendo".

An.: "E você, o que fala?"

S.: “Ah, eu notei que eu tô me machucando muito querendo acertar”.

An.: “Como é isso, Soledad?”

S.: "Eu sofro com isso, porque você sempre quer ser a melhor, sempre quer ser a melhor, se você tirou o segundo lugar você chora...

An.: "Você chora..."

S.: "Chorar assim entre aspas, né. Não que eu chegava a chorar, mas queria sempre ser a primeira. Aí quando vinha, tipo, a segunda, a terceira, eu ficava decepcionada comigo mesma”.

Soledad fala, então, de sua entrada no colégio e de como isto, de certa forma, selou seu destino. Após ter realizado o primeiro teste de Q.I., os resultados apontaram para a possibilidade de ingresso na segunda série, quando Soledad ainda tinha idade para frequentar o Jd. I. Nessa época, ela ainda tentou se posicionar de um modo diferente.

S.: "Eu teria que ter entrado na escola mais cedo, mas eu brequei o negócio. Eu não estava me dando bem com aquele pessoal mais velho, eu queria ficar com gente da minha idade, com meus amigos, então eu falei: 'mãe, eu não quero isso!' Aí não, aí não rolou”. 
Interessante observar como Soledad se manifesta como se fosse senhora absoluta de si, o Eu todo-consciência do qual Lacan (1960) fala em Subversão do sujeito e dialética do desejo no inconsciente freudiano. Onipotência, diriam os kleinianos, entretanto Lacan enfatiza que a onipotência de que se trata é a onipotência do Outro. À princípio, do Outro parental, agora, também do Outro social. Soledad é matriculada num colégio que zela "pelas melhores cabeças”, que articula uma infinidade de competições e testes a fim de localizar os alunos mais inteligentes dentre aqueles que já carregam esse rótulo.

Não bastasse isso, Soledad começa a ampliar sua busca, sua demanda de saber sobre o desejo Outro que, em última instância, significa querer saber sobre seu próprio desejo. Entretanto, o caminho escolhido por ela aponta correlativamente para um gozo. Um gozo em repetir a mesma cena que lhe trazia tanto sofrimento, e que a remetia aos enlaces do desejo materno, e que se constituía, para Soledad, ao mesmo tempo, num enigma sexual. Um enigma que a colocará em marcha, e que podemos verificar, sobretudo, em sua aproximação de pessoas mais velhas, preponderantemente mulheres, das quais almeja encontrar respostas para os mistérios de sua própria sexualidade.

Soledad começa, não só, a se relacionar com pessoas mais velhas, como a computar as diferenças: de sexos, de potência, de conhecimento...

Ela dá continuidade a sua investigação e, fala de como iniciou esse convívio com essas pessoas, ainda na primeira série.

S.: "Tinha umas meninas que a gente conversava, elas estavam na oitava série, mas acho que isso não influenciava muito. Porque a gente não ia conversar sobre a equação de não sei quantos graus - que elas ficavam falando. A gente ia conversar sobre um assunto fácil, um assunto simples. Porque nem sempre é legal você conversar sobre aquelas coisas, você acaba sendo muito chato”.

An.: "Sobre aquelas coisa..."

S.: "É, porque, às vezes, vamos supor que você lê um livro sobre numerologia, aí você começa a aplicar aquele negócio... Se a pessoa chegou e pegou a conversa no meio, ela vai saber o que você está falando? Ela vai entrar e dizer: ‘o que é isso?!' E ela vai sair”. 
O que haveria de tão impronunciável de modo que fosse necessário se referir a ele com adjetivos como: “aquelas coisas”, “aquele negócio”, levando alguém desavisado sobre o assunto a abandonar a conversa ao se deparar com seu conteúdo? An.: "O que é isso?!"

Retomo sua fala.

S.: "Então, assim... Eu acho assim, ninguém gosta de conversar sobre assuntos aprofundados demais”.

An.: “Assim como acontecia com os seus pais, quando você perguntava sobre sexualidade?”

S.: "É... porque os meus pais não estavam preparados pra tudo isso tão cedo assim... Eles não tinham coragem de falar, então eles compravam livros, né. Acho que essa coisa assim de você crescer muito cedo... Até que os pais esperam que o filho vá se interessar por isso lá pelos nove/onze anos de idade, mas pega uma criança de seis anos perguntando disso, caramba, como eu vou falar disso pra ela?”

An.: "E como você ia falar disso pra ela?"

S.: "Eu não, eles deviam imaginar como era falar disso pra mim...”

An.: "E como foi pra você?"

S.: “Às vezes, eu achava que as coisas iam passando rápido demais pela cabeça”.

Soledad começa, então, a fazer um outro sintoma.

S.: "Quando eu pensava muito rápido no que eu tinha de pensar, eu começava a pensar em coisas inúteis, tanto é que algumas vezes eu adquiri algumas manias. Eu comecei aquela coisa de igualdade até com meu irmão (refere-se às tarefas e aos direitos que passa a reivindicar que se façam da mesma maneira para ela e para o irmão). Isso subiu muito à minha cabeça, aí eu peguei uma mania, eu comecei a impor uma mania de ver de que lado eu mastigo mais que o outro. Se eu mastigo dez segundos uma coisa de um lado, tenho que mastigar dez segundos aquela coisa do outro lado”.

Ao se deparar com a falta, com a impossibilidade de saber sobre o gozo sexual e com a incompletude do Outro, Soledad busca abolir a diferença, primeiro em relação ao irmão e depois através de rituais obsessivos. Soledad, no entanto, continua a pensar que um dia saberá...

S.: "Uns podem ter mais facilidade em A, outros têm mais facilidade em B e tem outros que não têm facilidade nem em A e B, mas em C. Então, assim, eu acho que 
são áreas diferentes. Eu posso ter aquele potencial quando eu tiver quatorze anos, ou posso ter quando eu tiver doze, ou dez, ou posso ter quando eu tiver dezoito, mas eu vou ter aquele potencial de qualquer jeito... Talvez agora o racional possa ser maior do que esse lado psicológico... Pode ser que esse racional nunca pare de aumentar... Mas esse psicológico vai ter uma hora que vai disparar..."

Soledad começa a falar de sua relação com as meninas, com as mulheres e de sua investigação acerca do modo como gozam. A partir da diferença de idade, colocam-se questões associadas a diferenças de saber, à castração feminina e ao corpo. Corpo este que não dá à Soledad acesso ao ato sexual, mas que começa a pulular fazendo emergir uma voz Outra, que Soledad teme não conseguir conter. Se antes ela era apenas cabeça, algo agora lhe escapa e ultrapassa seu conhecimento.

E ela nos fala disso a partir de sua relação com as colegas do curso de inglês. S.: “Tem umas meninas lá que a gente se dá bem, ela tem dezoito anos, eu tenho onze, vou fazer doze. Aí tudo bem, a gente estuda bem, normal, porque assim, eu queria conversar com ela. Então elas não faziam questão assim, mas elas também queriam conversar comigo. Então houve um mutualismo. Eu conversar com elas e elas conversarem comigo. E a gente foi desenvolvendo esse negócio, e aí às vezes eu até falo: ‘por que eu não sou da sua idade também, eu estou tão bem, por que não?” An.: "Como assim, Soledad?"

S.: "Às vezes dá vontade de ser mais velha. Porque às vezes eu queria sair à noite. Só que eu não tenho idade ainda. Sair à noite, fazer algumas coisas que eu ainda não posso... Por causa desse meio até que convive, você pode às vezes ter mentalidade mais velha..."

An.: "Mas..."

S.: "Se eu tenho vontade, se eu tenho capacidade disso, por que eu não posso? Aí eu comecei a entender... Porque você não tem corpo, você não aparenta idade, você é mais fraca que os outros. Os outros podem te obrigar a fazer uma coisa que você não quer... Então você pensa: 'Espera aí, guarda esse negócio, guarda isso, guarda ele aí por uns três, quatro anos, que depois você coloca tudo pra fora de noite...”

An.: "Você fala que 'os outros podem te obrigar a fazer o que você não quer?!'”

S.: "Eu não quero, eu não quero tanto assim. Então, acho que é bem isso assim, espera aí, se você começa a sair muito cedo, você provavelmente começa a cair numa promiscuidade muito cedo. Você talvez não tenha consciência do que você 
está fazendo naquela emoção e você acaba pegando uma doença, pode morrer... Então, tem aquela coisa assim, que você sabe quais vão ser as consequências... Então, espera aí, vamos com calma. Pode até poder mentalmente, mas fisicamente você ainda não pode”.

Soledad fala de sua entrada na quarta série - período em que as questões da adolescência e da sexualidade começaram a se colocar para ela de modo mais contundente, e que o fantasma da exclusão volta a lhe assombrar. Primeiro porque se apresenta a possibilidade de que o irmão também seja superdotado - nos esportes algo em que ela não se sai bem. Segundo, que os colegas na escola passam a marcar uma diferença.

S.: Na quarta série teve umas meninas que começaram... Umas meninas que sempre foram amigas minha e que me excluíram, de uma certa forma por eu ser intitulada Cdf. Então, aí teve esse problema. Aí eu ficava triste, aí eu falei: 'Caramba, por quê? Por que isso? Por quê?’ Porque assim, é chato você tá com uma pessoa que ela acerta sempre”.

An.: "É chato você estar com uma pessoa que acerta sempre... Você diz isso pensando do lado quem ?”

S.: "Dessas pessoas que convivem comigo... Assim, eu não entendia, mas eu comecei a entender isso".

Soledad continua a responder do olhar do Outro. E, neste momento, um segundo teste se apresenta, frente ao qual Soledad se vê impelida a repetir um mesmo posicionamento anterior.

Ela nos fala.

S.: "Mas aí teve um teste, né. Aquele desafio que tem no Objetivo todo ano, pra quarta e oitava série. Eu não me lembro que colocação eu peguei, eu só sei que eu não peguei nem o primeiro, nem o segundo lugar. Eu quase caí! Eu falei: 'Como?' Eu cheguei em casa, falei que não queria mais estudar naquele colégio, era uma injustiça.

Chorei, nossa. A minha mãe até pensou em me tirar do Objetivo. Eu me deparar com esse teste foi traumático. Eu sempre quero tirar dez, sempre, só que tem vez que não dá. Eu vejo onde estou errando, aí tento consertar, mas nem sempre dá".

De que queda e de que objetivo Soledad fala? 
A queda aqui não estaria relacionada a possibilidade de não responder ao desejo da mãe, que teve como objetivo primeiro, desde a infância, ter um filho superdotado?

Soledad fornece mais exemplos do que acontece em termos de repetição dessa identificação a um significante que a coloca na posição de objeto. Continua a falar de exclusão.

S.: "Eu acho que quem exclui é o preconceito..."

An.: "Mas tem esse preconceito?"

S.: "Às vezes, poucas vezes, mas tem. Sempre tem. O que eu acho interessante é que quando tem competição de matemática na sala, todo mundo quer esses intitulados Cdf no seu grupo.

Eles brigam, eles puxam: 'Não, é minha, é minha'. Eu não preciso deles, mas eu não gosto de ficar sozinha. Na aula de educação física, eu não faço questão de jogar, nem os outros fazem questão que eu jogue. Se um grupinho quer ir ao shopping, tipo, que não é Cdf, que é aquela pessoa mais normal, quem tá mais adequada pra aquelas meninas, vai..."

Vemos, neste trecho, entre outras coisas, que ser superdotado, para Soledad, tem a conotação de ser anormal. Esta também parece ser a visão de seu pai. Quando lhe perguntamos se em algum momento chegou a imaginar a vinda de um filho como Soledad, este responde: "Não, de modo algum. Nós nunca pensamos isso. Todos os pais querem que os filhos sejam normais".

Soledad prossegue seu relato.

S.: "Eu, por exemplo, vou ao shopping com as minhas amigas, porque elas não me excluem, porque a gente tá acostumada com isso".

An.: "Com ser excluída..."

S.: "É, então a gente nem liga mais, já é uma coisa normal".(Silêncio).

An.: "Você falava que tem o grupo das meninas com quem você vai ao shopping, que não é o grupo que te chama pras questões de matemática, me fala mais disso". S.: "Ah, essas meninas, elas sabem o que é isso, porque elas já viveram isso e também elas, elas me ajudaram a pensar".

An.: "Isso, do que você está falando, Soledad?"

S.: "Ah, de baixo auto estima... Às vezes, aquela minha amiga, aquela que eu falei que tá adiantada, ela se sente menos do que os outros..." 
An.: "E você?"

S.: "Acho que eu já tive uma auto estima mais baixa. Minha mãe vivia falando pra mim: 'Se você não gosta de você mesma, ninguém vai gostar".

An.: E o que você pensa disto?"

S.: "Ah, eu penso que é porque eu dava muita importância pros outros, pro que os outros pensavam de mim, pro que os outros achavam. Então eu sofria muito quando alguém falava que eu não era aquilo que eu pensava que eu fosse".

An.: "E o que você pensava que fosse?"

S.: "Não sei, eu não lembro, assim... Mas eu sei que os outros me excluíam, eu não lembro por que, só que aí eu ficava com auto estima baixa, me achava um lixo. Aí eu comecei a parar pra pensar nisso. Quando eu comecei a me garantir, quando eu realmente comecei a gostar de mim mesma, o povo foi chegando, porque quando você não gosta de si mesma, você só fica no pé dos outros, ninguém vai gostar de você, nunca. Então você tem que gostar de si mesma... Entre aspas, é até bom você se achar o máximo".

An.: "Você há pouco dizia que se sentia um lixo, agora você está me dizendo que se acha o máximo, não tem uma contradição aí?"

S.: "Não, a minha expectativa em relação a mim mesma é um tipo, eu ainda sei o quanto eu sou capaz, eu confio em mim mesma, eu confio no meu taco. Eu sei que eu posso".

Constatamos o quanto se colocar numa posição fálica, o quanto defender a posse de um falo, de "um taco”, constitui-se na única forma apre(e)ndida por Soledad no sentido de lhe sustentar, de lhe dar garantias, ainda que ilusórias, frente à castração, à diferença. Diferença esta que se encontra cravada no corpo, tomemos isto seja pela superdotação, ou seja, pela própria falta de pênis.

Evoco-lhe uma passagem na qual faz referência à sua posição de objeto do outro.

An.: "Você me falava também das olimpíadas de matemática, que os teus amigos te puxam..."

S.: "Assim, porque teve uma vez, nesses jogos, que faltou uma integrante, um integrante ou dois da nossa equipe. Eu e a M. estávamos na mesma equipe. Aí, o que aconteceu? Eles usaram Eu e a M.. A outra equipe ficou p. da vida, porque eles não tinham ninguém pra usar". 
An.: "Pra usar?!"

S.: "É, a gente fica meio como objeto, é isso, exatamente".

An.: "E como é isso pra você?"

S.: "É, esse negócio de ser cobiçada pelo grupo é bom pro ego até uma hora, mas depois você vai parar pra pensar... Espera aí, eles estavam me usando, eles não estavam realmente interessados em mim..."

An.: "E então...?"

S.: "Assim... Ah, nem ligo... Acho..." (Silêncio).

S.: "Depois eu comecei a reparar que ninguém me queria em certas coisas e que alguém me queria muito em outras. Então, espera aí, tem alguma coisa errada. Se eles realmente quisessem mostrar que eu era boa em realmente tudo, eles me chamariam pra tudo. Agora, se eu só sou boa nessa parte e não sou boa naquela, quer dizer que eles estão me usando e me excluindo das outras. Aí foi aquela coisa... Se eu não posso ir na outra eu não posso ir nessa, só que se eu não for nessa eu não vou em nenhuma. Então, assim, você cria como uma defesa você não pensar nisso. Você tem consciência de que isso acontece, mas pra você não ficar magoada, pra você não ficar triste sempre, você não pensa nisso".

An.: "Então falta alguma coisa..."

S.: "É... E, às vezes, não devia, mas às vezes eu acabo usando o racional como um escudo, de não ter... Como um complemento do outro. É inevitável. eu sei que eu não posso, mas eu faço. É aquela coisa, não se pode ser perfeita... Embora se queira".

Soledad fala de sua condição de "não ter", de sua condição de ser faltante, o que a distancia de seu ideal de perfeição e, consequentemente, do que seria também o ideal parental.

Em seu endereçamento às figuras femininas, notamos ainda, que o sexo oposto não lhe faz questão, provavelmente por encontrar-se condizente com o que seja a ordem fálica do mundo, isto é, eles possuem pênis. Como tal, não precisam se empreender em certas tarefas, a fim de garantir seu lugar. Ao menos, esta parece ser a crença de Soledad. Seu conhecimento não lhe dá conta de que, no nível do saber, todos são faltantes, independente de sexo.

Recortamos um pequeno trecho, no qual Soledad revela o que pensa acerca da diferença entre meninos e meninas. Diferença que ela situa em relação ao único ponto sobre o qual acredita garantir-se, ou seja, o intelectual. 
S.: "Os meninos não, os meninos nem se preocupam assim em tirar uma nota mais alta do que você. Eles não tão nem aí. Agora uma menina tirar uma nota mais alta que você, é aquela coisa... Uma quer tirar mais que a outra. É aquela competição, assim. Apesar de ser ruim, ela não pára de existir. Estimula, né. Eu adoro uma competição. Então uma quer tirar mais que a outra. Então é isso, eu acho que com menino... menino não liga muito pra essa coisa de tirar sempre dez".

An.: "E por que menina precisa tirar sempre dez?"

S.: "Ah... Menina é mais... eu acho que tem uma coisa, assim, aquela inveja, aquela competição... Por que eu não posso ser igual a ela? Por que eu sempre fico atrás dela?"

Ao buscar soluções para o que concerne ao masculino e ao feminino, Soledad não estaria se referindo também à uma tentativa de dar sustentação para questão do que é ser mulher? Ou seja, para o fato de a mulher não existe?

Além disso, Soledad fala de inveja acerca da figura feminina. Mas, não deveria ser justamente o contrário, em relação ao pênis do menino?

Este ponto requer um certo cuidado, ao ser abordado, isto porque acreditamos estar diante de um traço de estrutura que se encontra associado à vários fatores.

Primeiramente, podemos verificar que há algo endereçado à própria figura materna, mais precisamente no que esta se apresenta como castrada, remetendo Soledad também a sua própria castração. Soledad, tal como constatamos nos textos freudianos, não se conforma em não ter o falo e culpa sua mãe por isso, de maneira indireta, estabelecendo diversos tipos de competição, a fim de mostrar sua supremacia sobre as mulheres, ao mesmo tempo em que procura aprender com elas sobre como gozam. Os parâmetros, neste caso, se traçam entre conhecimento e saber, além do despertar de uma sexualidade para a qual Soledad não se encontra aparelhada, e cujo conhecimento não é capaz de responder.

Por outro lado, devemos pensar ainda o que de um desejo pela figura do pai não estaria presente nesta fala: "Por que eu não posso ser igual a ela? Por que eu sempre fico atrás dela?” De que ela Soledad nos fala? Não poderia ser da mãe?

Busquemos verificar o que acontece entre Soledad e as figuras parentais. An.: "Me fala do relacionamento com seus pais..." 
S.: "Normal. Eu acho que eu me relaciono até melhor com a minha mãe, porque o meu pai é mais bravo. Ele é aquela coisa mais rígida. Porque quando, às vezes, eu acabo brigando, eu fico possessa, porque eu não sou flor que se cheire e nem ele .

Então a gente acaba brigando um com o outro e fica assim, com os nervos à flor da pele. Ele esquece rápido, mas depois eu fico remoendo, remoendo, aí eu falo: 'caramba, se eu continuar assim eu vou odiar o meu pai'. Bom, então eu brigo mais com meu pai do que com a minha mãe. Porque a minha mãe, a gente se entende melhor. Meu pai já não é uma pessoa flexível. Não é uma pessoa que você pode ter... Porque assim, embora eu saiba que isso não é certo, eu adoro ter controle sobre as pessoas, sobre a situação. Então, a minha mãe, de certa forma, eu consigo controlar. Ela sabendo disso, ela me deixa controlar. Ela me controla mas ela finge que me deixa controlar. Mas o meu pai nem fingir finge. É... Mas tudo bem... Acho que isso acontece assim, porque a minha mãe acho que ela deve saber mais ou menos o que é isso..."

Duas coisas, pelo menos, se verificam neste relato e que, talvez, respondam à nossa questão anterior. A primeira delas é o que Soledad coloca quanto ao fato de o pai “não ser alguém que se pode ter”, embora ela expresse, veladamente, este desejo. A segunda, diz respeito à identificação com a mãe - fálica, por suposto - o que lhe confere sua posição masculina. Parafraseando, Silveyra (1999) trata-se de “uma identificação com a mãe, que se faz sintoma, sendo uma maneira de não saber sobre a castração” (p.35).

Em outras palavras, poder-se-ia dizer que, a própria superdotação de Soledad se constituiria numa espécie de sintoma, envolvendo, de certa forma, um modo de Verleugnung, de um desmentido, que aponta para um nada querer saber acerca da diferença.

Para finalizar, Soledad fala sobre a solidão e a perda de sua infância.

S.: "Solidão, acho que agora não mais, mas acho que há um ano atrás, um ano e meio atrás, eu comecei a colocar culpa nos meus pais porque eles não sabiam que não tinha menina nesse bairro. Então eu sentia falta, porque o meu irmão sempre saía pra brincar com os amigos dele, e eu não tinha nenhuma menina pra brincar comigo. Então eu me sentia sozinha, me sentia muito sozinha. Assim, acho que agora não mais, acho que agora menos... Às vezes, dá aquela coisa, assim: 'ah, bem que eu 
podia ter alguém pra brincar agora, né!' Mas há um ano, dois atrás, a coisa foi muito forte, eu ficava realmente revoltada com os meus pais".

An.: "Com seus pais...?"

S.: "É, por eles terem mudado de casa..." (Silêncio).

An.: "Continua".

S.: "É porque eu sempre fui responsável demais, desde quando eu era pequenininha. Então quem sempre fazia tudo era eu, foi sempre eu... E, não sei, o meu irmão não se preocupa muito com isso, ele é realmente criança, então ele é sempre mais desligado. Comigo, os meus pais sempre falam: 'Como que você fez isso?' Como se eu fosse realmente adulta". (Silêncio).

An.: Você me dizia também que não gostava de ser criança, que num certo sentido era melhor estar com pessoas mais velhas..."

S.: "É que eu acho que quando eu tô com pessoas mais velhas é como se essa solidão, de alguma forma, fosse suprida... Mas se você convive com pessoas mais velhas, você está realmente convivendo e funciona, a sua solidão é meio suprida, uma parte dela. Você tem aquela necessidade, porque um cara de dezesseis anos, uma menina de dezesseis anos, não vai querer brincar de esconde-esconde, de pegapega... Ah, tem aquela coisa, eu tenho boneca até hoje. Nunca deixei elas irem embora, porque eu tinha minhas primas que vinham aqui em casa e gostavam de brincar, então eu brincava também. Porque às vezes você sente falta. Às vezes, aquilo no momento supre, mas depois não. Depois vem aquele vazio..."

Marca-se novamente a falta e o sofrimento advindo desse enlace, alienante, ao desejo do Outro.E Soledad conclui: "Pô, eu queria ter alguém pra brincar". 


\subsection{Narciso: quando o desejo é de morte.}

"São narcisos as flores que se plantam sobre os túmulos e essas flores significam o entorpecimento da morte, mas uma morte que não é senão um sono...” (Chevalier, 1991).

Narciso é um garoto de 12 anos, “projetado” (sic) pela mãe desde o princípio para ser a criança ideal, o que incluía também sua superdotação.

Infelizmente Narciso se mostra apagado sob o desejo materno, o que também se revela na escassez de suas falas durante a entrevista: pouco mais de dez minutos, nos quais respondia através de monossílabos, em contraposição ao discurso da mãe, que precisou ser interrompido após uma hora e meia de exposição.

Neste trabalho, Narciso também será falado por nós e, muitas vezes, a partir do próprio discurso da mãe.

A priori cabe-nos ressaltar a importância deste caso por trazer nítido o entrelaçamento entre a história materna e a constituição subjetiva da criança.

Narciso é planejado num momento em que se coloca para a mãe, de modo mais claro, a insatisfação em sua formação profissional, a distância de um marido frio e racional como seu pai, sempre ausente devido as viagens de trabalho. Trabalho este "mais importante do que tudo na vida, inclusive, do que os filhos e a mulher" (sic). Insatisfações com relação a si mesma que, por vezes, surgem mascaradas em falas acerca de seus dois primeiros filhos - também espelhos de sua história -, considerados assim como Narciso superdotados pelo colégio onde estudam.

Neste sentido, Narciso surge como uma tentativa de suprir as faltas anteriores, “como um modo de ser aquilo que a própria mãe não pode ser totalmente, ou ter...” (sic).

Veremos que a história mal resolvida entre a filha e o pai se repete na escolha da mulher - por vezes ocupando uma posição adolescente, titubeante em suas escolhas, - com relação ao marido. O que nos remete à frase de Mannoni (1967), na qual ela nos fala que “a dinâmica Pai-mãe-filho está em ação bem antes do nascimento da criança e reenvia cada um dos pais à maneira pela qual eles mesmos viveram seus édipos e ultrapassaram as distorções ligadas ao desejo de incesto”. 
Ao longo do caso, constatamos de que forma Narciso passa a encarnar a imagem da mãe - aquela de uma criança calada frente ao discurso paterno. Mãe que ao deixar a companhia de seus pais para constituir sua própria família, se subtrai desse enredo articulado pelo discurso, repetindo sem saber sua história pregressa agora em outra posição, na figura do filho mais novo.

Passemos, portanto, a narrar mais detalhadamente, a história desta mãe, a qual tal como no mito grego, daremos o nome de Liríope.

Liríope nos conta que está em São Paulo há pouco tempo. Veio do sul do país devido ao trabalho do marido que lhe exige viagens constantes. Ao descrever esse novo ritmo de vida que se estabeleceu após seu casamento, vai discorrendo sobre sua história de vida em família. Fala um pouco de sua infância, de sua adolescência, de suas escolhas profissionais e, sobretudo, do relacionamento mantido com seus pais. Neste contexto, traz uma dinâmica bastante distante entre os membros da casa, na qual as obrigações e deveres vinham sempre em primeiro lugar, não havendo muito espaço para o diálogo ou para o afeto.

Ainda assim, Liríope foi uma criança voltada a atender os desejos do pai, homem severo, sério, diante do qual a menina não conseguia falar, e o qual lhe causava medo. Buscou nos vários cursos que fez na faculdade se enquadrar de algum modo ao que seriam as supostas expectativas do pai. No fim, como já era de se esperar, não conseguiu concluir nenhum dos cursos iniciados.

Por vezes Liríope deixava entrever sua insatisfação por não ter correspondido plenamente aos ideais de seu pai:

L.: “Não fui tão responsável quanto o meu pai queria, não consegui sequer dar seguimento a minha carreira... Não sei, acho que eu não fui tudo o que podia ser... Meu pai também estava sempre distante. Às vezes, eu sinto como se eu não fosse suficiente, ou que ele não se preocupasse mesmo comigo. Eu acho que eu fui, que eu sou inteligente. Mas não sei... as coisas que eu queria dizer, mostrar, às vezes... ele não queria escutar, olhar, dar muita importância... Acho que eu me sentia um tanto burra, às vezes".

Neste sentido, Narciso também pode ser pensado como uma tentativa de concretizar as expectativas de um avô, supostamente frustrado com o desempenho da filha. Uma maneira de reparar a falta materna. 
Em determinado trecho da entrevista ao descrever o modo severo e austero com que o marido se apresentava na maioria das vezes, Liríope se surpreende: “pensando agora melhor, parece que meu marido é uma cópia de meu pai. Até no trabalho. O importante para o meu marido é o trabalho, o trabalho está indo bem ele está bem...”. E acrescenta num trecho seguinte: “se eu observar bem, Narciso também é bem parecido com eles, que interessante...”

Ao falar de sua vida em São Paulo, Liríope deixa entrever a sua concepção de família:

L.: "Foi muito bom vir morar em São Paulo. E eu tive sorte, por incrível que pareça, eu vim morar justamente num prédio onde todas as pessoas moram longe da família, o que faz com que todos sejam muito mais tranqüilos...”

An.: “Com que todos sejam muito mais tranqüilos... Inclusive você?”

L.: “Acho que sim, minha família é muito complicada. Eles não se envolvem. Embora eu tenha sido a mais nova e bastante paparicada, ainda assim sinto que eles eram distantes, entende? Era um tanto superficial...”

E Liríope continua seu relato enfocando novamente sua relação com a figura paterna e sua dificuldade em fazer valer seu desejo em família:

L.: “Aprendi muitas coisas aqui... Aprendi a falar com as pessoas, pois eu era mais retraída, tinha um pai muito arisco. Aprendi a brigar quando preciso e a me relacionar, porque eu também não tinha essa coisa de afeto, de amizade... Coisa boa é você se desprender da família e andar com as suas próprias pernas...”

Liríope fala um pouco da relação com sua mãe:

L.: "Eu não agüento a minha mãe. Ela é muito diferente de mim. Quando eu vou visitá-la é só reclamação... Aí eu penso: 'que bom que eu estou aqui, bem longe disto"”

An.: A partir da sua história familiar como você pensa a sua família hoje?

L.: “Ah, eu penso muito nos meus filhos. Eu não gostaria que eles passassem pelo que eu passei, mas eu sei que a gente não tem como controlar isto não é?! Às vezes eu acho que eles são muito parecidos comigo, principalmente os dois primeiros”.

No decorrer do relato de Liríope, vê-se articular diferentes etapas e aspectos de sua vida, os quais associa com o próprio funcionamento dos filhos. Neste momento, ela parece não perceber o quanto Narciso, seu terceiro filho, também se constitui num espelho de uma de suas facetas. Na verdade, ela começa por descrever 
aquilo que chama de "seu lado adolescente, irresponsável e emotivo" - no que os dois primeiros filhos demonstram corresponder mais diretamente, - passando só a posteriori a perceber o papel ocupado pelo terceiro, como estando mais relacionado àquilo que ela própria almejava ser, aos seus ideais mais narcísicos. Mas, paradoxalmente, este também é o filho que mais se assemelha ao aspecto frio, distante e racional dos quais ela se queixa com relação ao pai e ao marido.

Liríope fala da história de superdotação na sua família, já que os três filhos foram diagnosticados como tal.

L.: “O primeiro dos três a fazer o teste no Objetivo foi o mais velho. Como eu já disse, ele é bastante inteligente, mas bastante irresponsável. Ele tira sete, oito, mas poderia ir bem melhor... Quando ele fez o teste o F. também fez, mas não passou. Eu fiquei com pena e pedi para a psicóloga dar um empurrãozinho, mas ela não quis ajudar, disse que qualquer problema que ele tivesse quanto a isto poderia fazer terapia...”

An.: "Como é esta questão, me explica melhor isso...”

L.: “Ah, não que eu quisesse que os dois fossem superdotados, eu até fiquei surpresa com o resultado do O., mas já que ele iria freqüentar o programa do colégio fiquei com medo que o irmão se sentisse inferior... queria que ele acompanhasse o outro. Depois de algum tempo pedi para repetir o teste e, desta vez, o F. passou. No caso dele eu não vejo nem um potencial tão grande na escola, o desempenho maior dele é com relação aos amigos, é nos relacionamentos... aquilo no que eu acho que não era tão boa”.

An.: "E no caso do Narciso?”

L.: “Ah, com o Narciso não foi surpresa alguma... eu queria que ele fosse superdotado... Porque você sabe, não é, senão ficava aquela competição... No caso do Narciso eu sempre soube que se ele fizesse o teste, eu tinha certeza que ele iria passar. Eu não posso dizer o que é, mas as respostas que ele dava eram diferentes, já com dois/três anos... O Narciso não é uma criança que diga: eu quero isso ou aquilo, pra ele o que der, o que fizer está bom...”

An.: "Como você em relação ao seu pai?”

L.: “Ai, agora você me pegou.(Ri). Acho que sim... Não, acho que não... Acho que não é assim, acho que é mais o jeito dele mesmo. Ai, será que eu exijo demais? Tá 
vendo, por isso que às vezes é bom a gente conversar com alguém de fora, a gente pensa em coisas que nunca parou antes pra pensar...”

(Silêncio).

E, Liríope conclui:

L.: "Mas numa coisa ele é diferente de mim: nas atitudes com os amigos. Ele não se joga nas coisas... Às vezes parece que ele é uma forma mesmo de resolver as minhas dificuldades, sabe? Aquilo que eu via no O. com relação à irresponsabilidade, ou ainda, o lado mais sentimental, mais sensível do F., parece que isto estava resolvido no Narciso. Ele não é nem muito emocional, como o meu segundo filho, nem irresponsável como o primeiro. Ele tem todas as qualidades que eu considero boas e que eu mesma queria ter e não consigo... ele é responsável, é mais centrado, aquilo que eu queria ser. Eu vejo com o meu segundo filho, ele não consegue ser completo. Ele erra de bobeira, por não ser tão detalhista, por ser ansioso, embora ele seja criativo nos relacionamentos. O Narciso não, ele já é mais completo. É dez em matemática, é dez no desafio, é sempre dez... O que você pedir pra ele, ele vai dar. Tudo de si! O que você propuser pra ele, o retorno é 100\%”.

Liríope em diversos momentos da entrevista fala da superdotação dos filhos e das dificuldades por eles enfrentadas como se falasse de si mesma. No trecho seguinte, ela se compara ao filho mais velho, inclusive, no que diz respeito à vacilação que demonstrara anteriormente quanto à sua própria inteligência:

L.: “Ah, eu fui tão irresponsável quanto eu vejo com o O.. Só que eu não sei se ele recebeu isto de mim... Ele tem mais dificuldade de... Não sei se é falta de inteligência ou se é falta de responsabilidade mesmo. Talvez agora eu pense que é falta de amadurecimento, que é falta de maturidade mesmo. Eu falo pra você que é falta de inteligência, mas talvez não seja isso não... Talvez seja falta de amadurecimento...” An.: "Você fala dessa dúvida quanto a ser inteligente com relação a você também..." L.: “É... coisas que eu gostava eu pegava muito fácil, na escola, em relacionamento, com as amizades... Pra mim é muito fácil... mas as coisas que eu não gostava, eu não me interessava por elas. Parecia que tinha um véu assim...”

An.: "Um véu?"

L.: "Sabe, uma coisa assim que hoje eu digo, se eu fosse mais consciente... Essa que é a minha questão, eu não ter consciência das coisas... eu não sei se isto é bom ou se é ruim... Eu, eu na escola tirava sete, cinco... e na universidade tirava dez, então, não 
tinha dificuldades. E, em relação aos amigos também tinha aquela coisa de gostar de ficar junto e tal, mas também se não tivesse não tinha problema, não tinha importância. Então eu vejo assim que se eu tivesse dado mais atenção, fosse mais detalhista, né...”

An.: "Você seria uma superdotada?"

L.: “Talvez. (Ri). Não sei, acho que eu sempre tive essa questão...” (Silêncio).

An.: Antes, você me disse que ter filhos superdotados, principalmente o Narciso que você programou, a realiza de algum modo como pessoa. E, no seu caso, a quem você realizaria?”

L.: “Ah, não sei... Não sei se eu queria ser assim, superdotada. Talvez, a minha família, o meu pai... Ele sempre prezou esse lado do trabalho, da responsabilidade, do desempenho. Meu pai é uma pessoa que se inicia uma coisa não começa outra enquanto não acabar a primeira. Ele deixa tudo pra segundo plano até concluir aquilo com que ele se comprometeu. Ele foi sempre meio metódico. Eu não...”

Liríope fala de seus projetos, da gravidez dos filhos, de seu sentimento de incompletude e do que considera ser seu fracasso.

L.: "Você vê, hoje eu estou até trabalhando, antes eu não trabalhava... porque eu fiz colégio, depois fiz faculdade. Daí eu fiquei grávida do O. e, logo em seguida, eu fiquei grávida do F.. Então eu pensei: 'ah, na escola mesmo, quando eu tava estudando eu fiquei grávida do O.`. Só que eu não consegui me complementar, então essa minha falta de estudo, também é o que foi abaixando e fazendo que eu não tivesse coragem de seguir carreira. Quando eu fiquei grávida do F. eu não queria, porque eu sabia que eu tinha que seguir, mas não consegui me empenhar de novo... Até hoje me perguntam na escola quando é que eu vou voltar... Esquece, não vou, não vou de jeito nenhum”.

An.: "Não consegui me empenhar de novo..."

L.: "É, de novo. (Ri). Acho que eu não consigo dar cabo nas coisas que eu começo, e isso me faz sentir fracassada...”

Liríope fala de sua escolha profissional.

L.: “Ainda hoje eu vejo que não era esse o meu caminho. O que eu mais gosto é o trabalho com administração. Era mais esse o meu caminho, porque é essa coisa que 
eu gosto de fazer. E, só que pena, eu não tive preparo. Eu fui para uma área que eu não deveria ter escolhido”.

An.: "Por que você foi fazer veterinária?"

L.: "Humm, ah aquelas coisas de todo mundo querer fazer medicina e, eu resolvi que não ia estudar coisa nenhuma e resolvi estudar veterinária e pronto. Só que também por outro lado eu me desencantei muito, porque eu tinha a idéia - aquelas coisas de adolescente - de amar a natureza, foi muito bom no segundo grau, quando eles já falavam de ecologia, sobre o cuidado que eles tinham com a natureza, era mais ou menos isso que eu queria... acho que queria mais a faculdade de biologia e fui para a veterinária... Quando eu cheguei lá era um tal de criar vaca para matar, criar vaca para tirar leite... Era só o aspecto econômico mesmo... Tratar dos animais sob o aspecto econômico: cachorro, gato...”

Liríope fala então de sua semelhança com seu segundo filho:

L.: "É este tipo de coisa que eu vejo acontecer com o F., ele é muito inteligente, mas é muito emotivo, idealista, sofre muito com as coisas, depois se decepciona. O mundo não foi feito para pessoas como a gente...”

An.: "Como a gente..."

L.: "É... Acho que cada um dos meus filhos tem um pedacinho de mim... É que eu também sofri com essas coisas e ver meus filhos passando por isso hoje, pra mim é muito duro".

An.: "Você diz que cada um de seus filhos tem um pedacinho de você, como é isto com o Narciso?”

L.: "Bem, a história com o Narciso é um pouco diferente, porque o O. veio no susto, o F. também, aí eu queria ter um filho que fosse planejado, que fosse desejado... Então, o meu marido foi para o Japão. E essa ida dele para o Japão foi muito boa porque eu senti falta. Puxa, quanto tempo a gente ficou longe e agora a gente tá precisando falar e não dá... Eu senti falta... Então, pensei: vamos programar nossa vida, vamos fazer um neném, bem do jeito que a gente quer. Bom, programamos o nascimento do Narciso e, eu amei... Só que eu queria menina. Mas, mesmo assim, o Narciso foi uma benção!”.

Acerca do desempenho de Narciso soubemos, através da mãe, que ele é considerado um dos alunos mais inteligentes do colégio em que estuda, sendo sua nota mais baixa nove e meio. No entanto, no que concerne a sua posição como 
sujeito, coloca-se como totalmente apagado, mostrando-se sem voz diante da demanda avassaladora da mãe, ao menos, é assim que ele se porta durante a entrevista, a qual ele inicia dizendo estar nervoso.

An.: “O que você pensa disso que falam de você ser superdotado?”

N.: “Acho que é pra incentivar”.

An.: "Pra incentivar..."

(Silêncio)

An.: "O que é ser superdotado pra você?"

N.: "É quem tem mais facilidade..."

An.: "E você acha que é superdotado?”

N.: "Não. Mas eu acho que eles acreditam que eu sou. Mas eu acho que é normal ser assim...”

An.: "Eles acreditam que você é? Me fala mais disso..."

(Silêncio).

An.: “Quando disseram que você era superdotado?”

N.: "Eu soube quando eu entrei no POIT. Tinha sete/oito anos. Tinha que fazer um teste, aí eu fiz”.

An.: "E o que você sentiu, o que você achou?"

N.: "Não sei. Não sei o que falar..."

An.: "Fale o que você pensa".

(Silêncio).

An.: "Como você é na escola?"

N.: "Eu vou bem em todas as matérias, mas de matemática e de história eu gosto mais”.

An.: "E nos relacionamentos?”

N.: "É normal..."

An.: "Normal..."

N.: “É... Às vezes, as pessoas provocam. Tiram o sarro, dizendo que é cdf, mas é passageiro. Eu não ligo. Não tenho dificuldades com isso...”

(Silêncio).

An.: “E com seus irmãos?”

N.: "É normal".

(Silêncio). 
An.: "Você sempre fala pouco assim?"

N.: "De um modo geral, eu sou mais tímido. Não sei... Tem gente que fala demais... Abrem a boca na hora errada, não pensam direito”.

(Silêncio).

An.: "E com seus pais, como é?”

N.: “Com a minha mãe, às vezes, tem que fazer algumas coisas contra a vontade”.

An.: "Que coisas?"

N.: “Não sei, não lembro".

An.: "Não lembra ou não quer falar delas?”

N.: "Não sei o que falar".

An.: "Não sabe o que falar..."

(Silêncio).

An.: "E sobre o seu pai?”

N.: “Meu pai está no Japão. Desde que eu sou pequenininho que ele está sempre longe. Eu sinto falta dele, ele viaja muito...”

An.: “O que ele faz?”

N.: "Ele é engenheiro... É o que eu quero fazer também... No ano passado eu até fiz aula de robótica, tecnologia na escola... Tendo facilidade a gente pode escolher qualquer coisa que quiser...”

Embora Narciso diga não se considerar superdotado sabe que este é o desempenho esperado dele, e responde desse lugar. Isto parece evidente se retomarmos a frase na qual nos diz: "eu acho que eles acreditam que eu sou. Mas eu acho que é normal ser assim”.

Um outro fator a ser ressaltado é o uso que Narciso faz desse posicionamento: “tendo facilidade a gente pode escolher qualquer coisa”. Talvez ele não tenha a dimensão do preço que paga por essa “escolha” - a de responder ao desejo materno e, muito menos a idéia da ambigüidade envolvida no termo qualquer coisa. Quando esse qualquer pode representar, na verdade, uma renúncia a uma fala mais autêntica, mais genuína.

Além disso, é interessante observar que Narciso manifesta o mesmo sentimento de falta em relação ao pai, tal como ocorre na história de sua mãe. Mas não percebe, assim como ela, que a facilidade que tem devido à superdotação não resolve essa distância, não preenche essa falta. 
Diz não saber o que falar... Possivelmente não encontre espaço para se manifestar, uma vez que sua mãe se coloca como uma das pessoas que ele classifica como "não sabendo a hora certa de abrir a boca", como sendo "gente que fala demais”. O que aparece reforçado na última frase dita por sua mãe, durante a entrevista: "Quando eu era criança, morria de medo de abrir a boca, hoje o meu marido precisa pedir pra eu ficar calada, porque eu falo demais..."

Narciso estaria encenando a mesma história vivida por sua mãe? Será o desejo de Liríope o que cala a voz de Narciso, matando seu desejo e fechando-o em si mesmo?

Infelizmente, não há como responder... Esperamos, no entanto, assim como nas palavras de Chevalier, que essa morte não seja mais que um entorpecimento, $e$ que, tal como sua mãe, Narciso não precise esperar a saída de casa para desabrochar para a vida! 


\title{
5. (IN)CONCLUSÃO
}

\author{
“... o heim, este ponto que é unheim, dentro da experiência humana \\ é a casa do homem, este lugar que se situa dentro do Outro, este lugar \\ que representa a ausência onde nós somos o vazio, o buraco da cadeia \\ significante, a falta de significante do Outro. Este ponto nos revela a presença \\ em outro lugar, nos revela o - $\varphi$ não especularizável, nos revela a causa. \\ Enquanto causa, é o que insiste, é o que pulsa como resto, é a \\ compulsão à repetição, é o reencontro sempre faltoso”.
}

Jacques Lacan

Em psicanálise, é sempre difícil falarmos de conclusão, uma vez que sabemos jamais alcançar o objeto de nosso desejo, de nossa satisfação, de nossas pesquisas. Ao fecharmos uma etapa, já o fazemos tendo em vista as lacunas por ela deixadas, vislumbrando o momento de nos empreendermos numa nova caminhada.

Assim também tem sido nossa experiência neste percurso, onde, por vezes, nos vimos levados a nos precipitar na asserção de certezas antecipadas, mediante as diversas dúvidas que se apresentavam. Constituindo-se em verdadeiros enigmas a serem de-cifrados, e nos impelindo a buscar saídas, respostas... Estas, quase sempre, insatisfatórias, repetindo os fracassos, os recuos e avanços das primeiras investigações - de um tempo remoto - da constituição infantil.

Mas, se Lacan em um dado momento de sua obra, já ressaltava que "tudo que é da ordem da criação se dá na descontinuidade e sob o domínio da urgência”, conformemo-nos com a impossibilidade de fechamento e, passemos a falar, então, do que apre(e)ndemos, ao lançarmos um outro olhar, acerca do sujeito superdotado.

Para esta tarefa, enfatizamos que, embora tenhamos apresentado apenas dois dos cinco casos acompanhados nesta pesquisa, para efeito de conclusão, utilizaremos dados obtidos em toda amostra. 
Neste sentido, o que observamos, de um modo geral, é que uma resposta pela via intelectual se mostra, proporcionalmente, relacionada à estruturação psíquica do sujeito, estando, em muito, associada ao modo como este se encontra referido à castração e à demanda do Outro.

O primeiro aspecto a se colocar, no processo de constituição do superdotado, diz respeito à articulação da superdotação ao fantasma parental, tendo sido possível constatar a presença maciça da sexualidade dos pais, sobretudo, no que esta se refere ao desejo materno.

Pudemos constatar, a partir da escuta das mães desses sujeitos, a existência de uma história pregressa, antecedente mesmo à ocasião do nascimento de seus filhos, tempo este referido à infância materna, no qual já se marcava um certo posicionamento fálico por parte dessas mulheres, havendo o desejo, muitas vezes manifesto, em sustentar este lugar. Desejo este viabilizado, no presente, a partir da chegada de um filho superdotado.

Não só o desejo materno encontrava-se desvelado, como toda uma configuração familiar que se mostrava por meio da própria escolha objetal dessas mulheres. De diferentes maneiras, elas relatavam episódios relacionados a seus pais, deixando entrever a influência desses relacionamentos sobre a escolha de seus parceiros. Ao mesmo tempo, em que não conseguiam separar sua própria história da história constituída, por elas, para seus filhos.

Tornava-se claro que estes faziam parte de um projeto articulado, meticulosamente, embora de maneira inconsciente, tal como um presente a ser ofertado a um pai, tal como um substituto capaz de recobrir as perdas de infância, de recobrar o tempo perdido, os amores perdidos, os ideais...

E o sujeito? O sujeito se constituiria neste objeto idealizado, que viria responder prontamente à demanda incondicional do Outro, dada sua dependência de amor.

Neste sentido, a superdotação pode ser considerada como um sintoma voltado a atender o desejo materno/mãe-avô.

Confirma-se, desta maneira, o que Mannoni (1988b) já citara anteriormente: “o que na mãe não pôde ser resolvido no nível da experiência da castração, vai ser vivido, como eco, pelo filho que, nos seus sintomas, muitas vezes não fará mais do que fazer 'falar' a angústia materna” (p.35). 
Outro fator importante, concernente à sexualidade da mãe e de seus filhos, foi levantado com base nas duas entrevistas realizadas com meninas, das quais apresentamos apenas o caso Soledad, onde ambas eram esperadas como meninos, tendo causado uma certa decepção com sua chegada.

Essas crianças, são descritas, ainda, ao longo de sua infância, como desprovidas de interesse por atividades ou brincadeiras femininas, dirigindo sua atenção para assuntos intelectuais.

Fazendo-se necessário ainda enfatizar que, embora as mães dessas meninas dissessem não saber dos fundamentos desse interesse intelectual, ambas zelavam por essa busca, sendo as grandes mentoras do posicionamento masculino de suas filhas. Posicionamento este que, por sua vez, elas também compartilhavam, e que atendia, ao menos parcialmente, as expectativas depositadas anteriormente acerca da posse de um filho.

Pautados nos textos freudianos, poderíamos situar esta busca em relação aos dois desejos que Freud (1924) cita como remanescentes da passagem da menina pelo complexo de Édipo e, que se constituem no desejo de possuir um pênis e um filho.

Pode-se ainda inferir que nos dois casos citados acima a superdotação se apresenta como um modo dessas crianças se colocarem a partir de uma posição masculina, atendendo, deste modo, ao que era o apelo inconsciente de suas mães.

Diante dessas duas vertentes que se colocam - a da criança superdotada e de sua mãe - podemos concluir que ambas buscam um modo muito peculiar de se posicionar frente à castração.

Além disso, nos casos acompanhados, ficou patente a atuação de uma operação significante, de uma operação de linguagem, como instituinte de um sujeito determinado a se colocar a partir do lugar de superdotado.

Sobretudo, no caso Soledad, pudemos pensar o termo superdotado como um traço unário, a partir do qual o sujeito pôde articular sua cadeia significante, marcando-se como sujeito dividido.

Sendo neste momento, em que se vê confrontado como sujeito à incompletude do Outro, que o sujeito se empreenderá nas investigações sexuais infantis. Fundando-se, desta forma, o que Freud (1908) denominou de desejo de saber, e que verificamos, pautados nos trabalhos realizados por Aulagner 
(1967/1980) e Kupfer (1990) tratar-se, na verdade, de uma demanda de saber, que impele o sujeito na busca de sua independência intelectual.

Como já dissemos no início deste trabalho, na insuficiência de um saber o desvelamento de uma verdade se impõe, empurrando o sujeito a buscar no Outro, pelas vias da suposição de um saber todo, a resposta que lhe falta.

Deste modo, responder como superdotado, constitui-se como uma forma de apontar para a instalação do desejo e da divisão, uma vez constatada a falta de pênis materna.

Sendo assim, ao encontrar respaldo no desejo parental e num Outro social que o legitima no lugar de superdotado, encontram-se traçadas as balizas para que o malestar - próprio da estruturação psíquica -, ceda lugar ao sofrimento gerado pela angústia da colagem a um significante, configurando-se o que nos permite elevar a superdotação ao estatuto de sintoma.

Assim, corroborando os dados levantados anteriormente, podemos dizer que o próprio conhecimento poderia fazer parte de um plus produzido entropicamente por um saber inconsciente cujo objetivo seria tentar responder a falta em ser do sujeito e, como tal, trazendo incutido sua parcela de gozo.

Cabe-nos enfatizar ainda que nestes casos deve-se considerar aquilo que Freud (1916-17) denominava séries complementares, e que se define como a associação de diferentes fatores a fim de se constituir uma dada dinâmica intrapsíquica, compreendendo, entre outros, os fatores inatos, a constituição sexual e a experiência do sujeito.

Dito em termos lacanianos, podemos articular esses fatores aos registros do real, simbólico e imaginário, o que nos permite afirmar que, no caso do superdotado contamos também com uma predisposição orgânica - relativa ao real do corpo -, a fim de que o sujeito possa responder à incidência da marca significante, em ação através do desejo materno.

Além disso, pudemos verificar nesses casos a presença de um mecanismo de transgressão, fundado por meio da sublimação. E que vem imputar ao sujeito um sofrimento, já que assumir a condição de superdotado significará também subverter, de algum modo, o saber do pai.

Estará sempre presente para o sujeito a questão da diferença, mas de uma forma muito específica, diríamos mesmo dúbia, uma vez que essa diferença o marca 
como supostamente perfeito em relação ao que a demanda social lhe exige e, ao mesmo tempo, como faltante, sendo na medida em que tenta responder a este ideal, que se deparará com a impossibilidade de acesso a um gozo Outro, logo vendo-se confrontado com sua falta em ser.

Trata-se de um sofrimento e de uma diferença real, no sentido proposto por Lacan, por meio dos quais o sujeito se encontrará frente ao que é a solidão que se institui a partir dos equívocos, dos mal-entendidos fundados pelo significante. E que, ao menos nos casos estudados, encontram-se situados para o sujeito no nível da impotência, ou seja, ele ainda acredita ser possível suprir essa falta, diminuir essa diferença, não conseguindo perceber a própria inconsistência do Outro.

Desta forma, sonha impossíveis que vê desmantelar-se sob o impacto, mesmo, daquilo que o marca como sujeito superdotado, e que encontra-se inacessível para ele.

Acordar desse sonho, ou, ao menos, aprender a lidar com os fantasmas que, às vezes, o transformam em pesadelo, é uma tarefa que só se torna possível para não muitos.

Assim, encerramos com um poema que pensamos, de certa forma, falar mais profundamente desse processo de construção, de encaixe da palavra perfeita e do estarrecimento diante do texto - falado ou escrito - que teima em se esfarrapar 


\section{A fábrica de poemas}

Sonho um poema de arquitetura ideal

Cuja própria nata de cimento encaixa palavra por palavra.

Tornei-me perito em extrair faíscas das britas e leite das pedras.

Acordo!

E o poema todo se esfarrapa, fiapo por fiapo.

Acordo!

O prédio, pedra e cal, esvoaça como um leve papel solto, à mercê do vento.

E, evola-se a cinza de um corpo esvaído de qualquer sentido.

Acordo!

E o poema- miragem se desfaz, desconstruído, como se nunca houvera sido.

Acordo!

Os olhos chumbados pelo mingau das almas e os ouvidos moucos.

Assim é que saio dos sucessivos sonos:

vão- se os anéis de fumo de ópio, e ficam-me os dedos estarrecidos.

Metonímias, aliterações, metáforas, oxímodos, sumidos no sorvedouro.

Não deve adiantar grande coisa permanecer à espreita,

no topo fantasma da torre, de vigia.

Nem a simulação de se afundar no sono, nem dormir deveras.

Pois a questão- chave é:

Sob que máscara retornará o recalcado?

Sob que máscara retornará?

Sob que máscara... 


\section{REFERÊNCIAS BIBLIOGRÁFICAS}

ALVAREZ, J.M. Toxicomanía y pathos del discurso. In: SINATRA, E.S., SILLITII, D. \& TARRAB, M. (comp.). Sujeto, Goce y Modernidad III - De la monotonía a la diversidad - Primera jornada sobre toxicomanía y alcoholismo del Instituto del Campo Freudiano. París, Atuel-Tya, julio de 1994.

AULAGNER-SPAIRANI, P. Le “désir de savoir” dans ses rapports à la transgression. In: KUPFER, M.C.M. O desejo de saber. São Paulo, Tese de doutorado, Universidade de São Paulo, 1990.

BION, W.R. (1988). Uma teoria do pensar. In: SPILLUS, E.B. Melanie Klein Hoje. Vol. 1. Rio de Janeiro, Imago, 1991, p. 183-193.

BLEICHMAR, S. Do discurso parental à especificidade sintomática na psicanálise de crianças. In: ROSENBERG, A.M.S. de (Org.). O lugar dos pais na psicanálise de crianças. São Paulo, Escuta, 1994.

CÂMARA, C. G. Auto-alfabetização precoce: indício de superdotação ou resposta a um ambiente rico em estímulos? São Paulo, 1999. 159p. Dissertação (Mestrado) - Instituto de Psicologia, Universidade de São Paulo.

CALLIGARIS, C. Introdução a uma clínica psicanalítica - seminários. Salvador, Cooperativa Cultural Jacques Lacan, 1986.

. Perversão - um laço social? Salvador, Cooperativa Cultural Jacques Lacan, 1986.

. Introdução a uma clínica diferencial das psicoses. Porto Alegre, Artes Médicas, 1989.

CLARK, B. Otimização do aprendizado: identificação, planejamento e recursos para jovens superdotados e talentosos. Resumo dos trabalhos. Congresso 
Internacional sobre superdotação, III Congresso Íbero-Americano sobre Superdotação, VII Seminário Nacional da Associação Brasileira para Superdotados. Brasília. Secretaria de Educação Especial / Ministério da Educação e do Desporto, 1998. p. 13-7.

CLAVREUL, J. La pareja perversa. In: KUPFER, M.C.M. O desejo de saber. São Paulo, Tese de doutorado, Universidade de São Paulo, 1990.

de LAJONQUIÈRE, L. Dos “erros” e em especial daquele de renunciar à educação. Notas de psicanálise e educação. Estilos da clínica. Revista sobre a Infância com Problemas. São Paulo, Pré-escola Terapêutica Lugar de Vida, IPUSP., 1997, 3(4): 65-79.

FREEHILL, M. F. Gifted Children - Their Psychology and education. New York, Holt, Renehart and Winston, 1961.

FREEMAM, J. The psychology of gifted children: Perspectives on development and education. Great Britain: John Wiley \& sons Ltd, 1985.

FRIEDENTHAL, R. Leonardo da Vinci - uma biografia ilustrada. Rio de Janeiro, Jorge Zahar Editor, 1983.

FREUD, S. A interpretação dos sonhos. Obras Completas. Rio de Janeiro, Imago, 1976. . (1905). Três ensaios sobre a sexualidade. Obras Completas. Rio de Janeiro, Imago, 1976.

. (1907). O Esclarecimento sexual da criança. Obras Completas. Rio de Janeiro, Imago, 1976.

(1908). Teorias sexuais Infantis. Obras Completas. Rio de Janeiro, Imago, 1976. 
- (1910). Leonardo da Vinci, uma lembrança de infância. Obras Completas. Rio de Janeiro, Imago, 1976.

. (1915). Luto e melancolia. Obras Completas. Rio de Janeiro, Imago, 1976.

- (1923). A organização sexual infantil. Obras Completas. Rio de Janeiro, Imago, 1976.

(1923). A feminilidade. Obras Completas. Rio de Janeiro, Imago, 1976.

. (1924). A dissolução do complexo de Édipo. Obras Completas. Rio de Janeiro, Imago, 1976.

- (1931). Sexualidade Feminina. Obras Completas. Rio de Janeiro, Imago, 1976.

GALTON, F. Hereditary Genius. New York, Mac Milhan, 1914 ( $1^{\mathrm{a}}$ ed., 1869).

GIBELO, B. A criança com distúrbios de inteligência. Porto Alegre, Artes Médicas, 1987.

HOBSBAWN, E. A era do capital. Apud PATTO, M. H. S. (1990). A produção do fracasso escolar. São Paulo, T. A. Queiroz, 1993, 385p.

JERUSALINSKY, A. Psicanálise: Instituição <> Transmissão. Porto Alegre, RS., Documento apresentado pela Associação Psicanalítica de Porto Alegre APPOA, s.d., p. 1-8.

KLEIN, M. (1923). O papel da escola no desenvolvimento libidinal infantil. Contribuições à psicanálise. Rio de Janeiro, Mestre Jou, 1970. 
(1930). A importância da formação dos símbolos. Amor, Culpa e Reparação e outros trabalhos. Rio de Janeiro, Imago, p. 251-264. .(1931).Uma contribuição à teoria da inibição intelectual. Amor, Culpa e Reparação e outros trabalhos. Rio de Janeiro, Imago, p. 269-282.

KUPFER, M. C. M. Relação Professor-aluno: uma leitura psicanalítica. São Paulo. Dissertação de Mestrado - Universidade de São Paulo, 1982.

O desejo de saber. São Paulo, Tese de doutorado, Universidade de São Paulo, 1990.

Freud e a Educação - O mestre do impossível. São Paulo, Scipione, 1992.

Pais: melhor não tê-los? In: ROSENBERG, A.M.S. de (Org.). O lugar dos pais na psicanálise de crianças. São Paulo, Escuta, 1994.

LACAN, J. (1949). O estádio do espelho. Escritos. Trad. Vera Ribeiro. Rio de Janeiro, Jorge Zahar, 1998. (Campo Freudiano no Brasil).

• (1954-1955). O seminário: livro 2 - o eu na teoria de Freud e na técnica da psicanálise. Texto estabelecido por Jacques-Alain Miller; Trad. Marie Christine Laznik Penot, com a colaboração de Antonio Quinet. Rio de Janeiro, Jorge Zahar, 1985. (Campo Freudiano no Brasil).

. (1957). O seminário: livro 4 - a relação de objeto. Texto estabelecido por Jacques-Alain Miller; Trad. Dulce Duque Estrada. Rio de Janeiro, Jorge Zahar, 1995. (Campo Freudiano no Brasil).

- (1960). Subversão do sujeito e dialética do desejo no inconsciente 
freudiano. Escritos. Trad. Vera Ribeiro. Rio de Janeiro, Jorge Zahar, 1998. (Campo Freudiano no Brasil).

(1960-1961). O seminário: livro 8 - a transferência. Texto estabelecido por Jacques-Alain Miller; Trad. Dulce Duque Estrada. Rio de Janeiro, Jorge Zahar, 1995. (Campo Freudiano no Brasil).

. (1962-1963). O seminário 10 - A Angústia. Recife. Centro de Estudos Freudianos de Recife. Publicação interna da Associação Freudiana Internacional.

- (1964). O seminário: livro 11 - os quatro conceitos fundamentais da psicanálise. Texto estabelecido por Jacques-Alain Miller; Trad. M. D. Magno. Rio de Janeiro, Jorge Zahar, 1985. (Campo Freudiano no Brasil).

. (1966). A ciência e a verdade. Escritos. Trad. Vera Ribeiro. Rio de Janeiro, Jorge Zahar, 1998. (Campo Freudiano no Brasil).

. Jornada de estudio de los carteles. Sesión de clausura. 1967. Inédito.

. (1969). Dos Notas sobre El Niño. Buenos Aires, Manantial, 1992.

- (1970). O seminário: livro 17 - o avesso da psicanálise. Texto estabelecido por Jacques-Alain Miller; Trad. Ari Roitman, Rio de Janeiro, Jorge Zahar, 1992. (Campo Freudiano no Brasil).

. Del Discurso Psicoanalítico. Milán, Universitá degli Studi, via Festa del perdono. 6,12 Mayo de 1972. Tradução de Osvaldo Arribas.

. (1972-1973). O seminário - livro 20: mais, ainda. Texto estabelecido por Jacques-Alain Miller; Trad. M.D. Magno, Rio de Janeiro, Jorge Zahar, 1985. (Campo Freudiano no Brasil). 
- (1974). Seminário XXI - Les non dupes errent. Inédito. Aula de 19/03/1974.

LANDAU, E. A coragem de ser superdotado. São Paulo, CERED, 1990.

LEMÉRER, B. Algumas reflexões a partir do texto de Freud sobre as teorias sexuais infantis. A criança e o saber. Letra Freudiana. Escola, Psicanálise e Transmissão. N. 23, p.13-20, 1999. Revinter.

LEWIS, M.; MICHALSON, L. The gifted infant. In: FREEMAM, J. The psychology of gifted children: Perspectives on development and education. Great Britain: John Wiley \& Sons Ltd, 1985.

MANNONI, M. Educação impossível. 2a ed. Rio de Janeiro, F. Alves Ed., 1988a.

. A criança retardada e a mãe. São Paulo. Martins Fontes, 1988b.

. Um saber que não se sabe. Campinas, Papirus, 1989a.

. Da paixão do ser à “loucura” de saber, os anglo-saxões e Lacan. Rio de Janeiro, Jorge Zahar Editor, 1989b.

MARANI, Pietro C. Les fleurons de L'art. Leonard de Vinci - Catalogue complet. Paris, Bordas, 1991, p. 113.

MASOTTA, O. Lecciones de introducción al psicoanálisis. In: KUPFER, M.C.M. O desejo de saber. São Paulo, Tese de doutorado, Universidade de São Paulo, 1990.

MILLER, A. O drama da criança bem dotada - como os pais podem formar e deformar a vida emocional de seus filhos. $2^{\text {a }}$ Ed. São Paulo, Summus Editorial, 
1986, 124p.

MILLER, J.A.. Para una investigación sobre el goce auto erótico. Sujeto, goce e Modernidad - Los fundamentos de la clínica. Buenos Aires, Atuel-Tya, 1994.

NASIO, J. D. In. HEINRICH, H. Cuando La Neurosis no es de Transferencia. Colección la clínica en los bordes. No. 11, p. 31, 1996, Homo Sapiens Ediciones.

NASIO, J. D. Lições sobre os 7 conceitos cruciais da psicanálise. Rio de Janeiro, Jorge Zahar Editor, 1988.

NEME, L. O a-prender na constituição do sujeito. A criança e o saber. Letra Freudiana. Escola, Psicanálise e Transmissão. N. 23, p.43-46, 1999. Revinter.

NIETZSCHE, F. (1883). Assim falou Zaratustra. Obras incompletas. Os pensadores, Abril Cultural, Editor Victor Civita, 1974.

NOBRE, L. De onde vêm os bebês? - Um impossível a saber. A criança e o saber. Letra Freudiana. Escola, Psicanálise e Transmissão. N. 23, p.29-32, 1999. Revinter.

NOVAES, M. H. O desenvolvimento psicológico do superdotado. São Paulo, Atlas, 1979.

ORTIZ, L. E. de. O superdotado, suas características e necessidades segundo pais, diretores e professores de escolas oficiais do Município do Rio de Janeiro. Rio de Janeiro, UFRJ, 1981.

PATI, V. T. Auto-percepção do superdotado. São Paulo, 1994, 176p. Dissertação (Mestrado) - Departamento de Psicologia clínica, Pontifícia Universidade Católica. 
PATTO, M. H. S. (1990). A produção do fracasso escolar. São Paulo, T. A. Queiroz, 1993, 385p.

PIAGET, J. Psicologia e epistemologia. Trad. Agnes Cretella. São Paulo, Companhia Editora Forense, 1973.

PORGE, E. Os nomes do pai em Jacques Lacan: pontuações e problemáticas. Rio de Janeiro, Companhia de Freud, 1998, 232p.

QUINET, A. As 4+1 condições de análise. Rio de Janeiro, Jorge Zahar Editor, 1998.

ROBINSON, N. M. The early development of precocity. Gifted Child Quartely, v. 31, no. 4, p. 161-4, 1987.

ROSENBERG, A.M.S. de (Org.). O lugar dos pais na psicanálise de crianças. São Paulo, Escuta, 1994.

ROSENBERG, R. L. Psicologia do superdotado. Rio de Janeiro, J. Olympio, 1973.

SEAGAL, H. Fantasia. Sonho, Fantasia e Arte. Rio de Janeiro, Imago, 1993, p. 3144.

. Simbolismo. Sonho, Fantasia e Arte. Rio de Janeiro, Imago, 1993, p.45-61.

Espaço mental e elementos do simbolismo. Sonho, Fantasia e Arte. Rio de Janeiro, Imago, 1993, p.62-74.

Notas sobre a formação de símbolos. In: SPILLUS, E.B. Melanie Klein Hoje. Vol. 1. Rio de Janeiro, Imago, 1993.

SILLITTI, D. La eficacia del nombre: los llamados adictos. Sujeto, goce e 
Modernidad - Los fundamentos de la clínica. Buenos Aires, Atuel-Tya, 1994, p.51-9.

SILVESTRE, M. A transferência é amor que se dirige do saber. In: KUPFER, M.C.M. O desejo de saber. São Paulo, Tese de doutorado, Universidade de São Paulo, 1990.

SINATRA, E.S. Variantes del argumento ontológico em la modernidad. Sujeto, goce e Modernidad - Los fundamentos de la clínica. Buenos Aires, Atuel-Tya, 1994, p.23-35.

SILVEYRA, M.L. Teorias sexuais e neurose infantil. A criança e o saber. Letra Freudiana. Escola, Psicanálise e Transmissão. N. 23, p.33-36, 1999. Revinter.

SOLER, C. Seminario do Campo Freudiano em Barcelona. In: SILLITTI, D. La eficacia del nombre: los llamados adictos. Sujeto, goce e Modernidad - Los fundamentos de la clínica. Buenos Aires, Atuel-Tya, 1994, p.51-9.

TARRAB, M.(1992) ... Mírenlos Cómo Gozan!! Sujeto, goce e Modernidad - Los fundamentos de la clínica. Buenos Aires, Atuel-Tya, 1994.

TERMAN, L. M. et al. Mental and physical traits of a thousand gifted children, genetic studies of genius. Vol. I, Stanford, California, Stanford University Press, 1925.

UNTERBERGER, M. (1992). Estatuto del “yo soy” en la toxicomanía y el alcoholismo. In: SINATRA, E.S., SILLITII, D. \& TARRAB, M. (comp.). Sujeto, Goce y Modernidad III - De la monotonía a la diversidad - Primera jornada sobre toxicomanía y alcoholismo del Instituto del Campo Freudiano. París, Atuel-Tya, julio de 1994.

VIDAL, E. A. Um outro saber. A criança e o saber. Letra Freudiana. Escola, Psicanálise e Transmissão. N. 23, p. 21-8, 1999. Revinter. 